CIHM Microfiche Series (Monographs)

\section{ICMH}

Collection de microfiches (monographies)
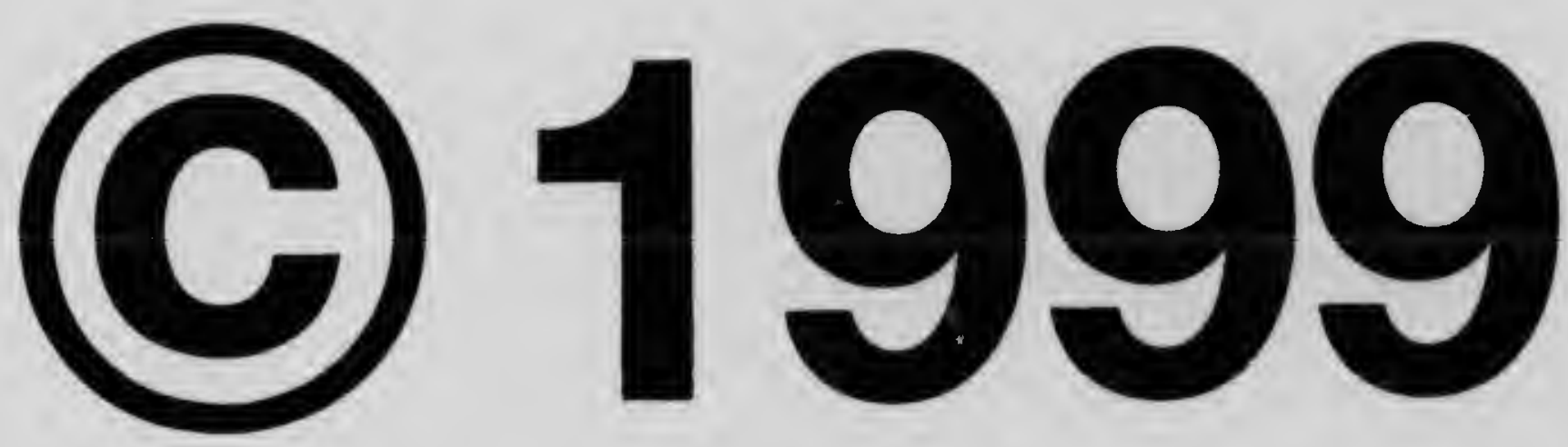


\section{Technical and Bibliographic Notes / Notes techniques et bibliographiques}

The Institute has altempted to obtain the best original copy available for filming. Features of this copy which may be bibliographleally unlque, which may alter any of the images In the reproductlon, of which may significanily change the usual method of filming are checked below.

Coloured covers I

Couverture de couleur

\section{Covers damaged /}

Couverture endommagée

Covers restored and/or laminated /

Couverture restaurée eVou pelliculée

Cover tille missing / Le titre de couverture manque

Coloured maps / Cartes géographiques en couleur

Coloured ink (1.e. other than blue or black) $r$

Encre de couleur (i.e. autre que bleue ou noire)

Coloured plates and/or illustrations I

Planches eVou illustrations en couleur

Bound with other material/

Relié avec d'autres documents

Only edition available /

Seule édition disponible

Tight blinding may cause shadows or distortion along Interior margin / La reliure serrée peut causer de l'ombre ou de la distorsion le long de la marge Intérieure.

Blank leaves added during restoratlons may appear within the text. Whenever possible, these have been omitted from filming / II se peut que certalnes pages blanches ajoutées lors d'une restauration apparaissent dans le texte, mais, lorsque cela dtait possible, ces pages n'ont pas été filmées.

Additional comments /

Commentalres supplémentaires:
L'Institut a microfilmé le mellleur exemplaire qu'il lui a été possible de se procurer. Les détails de cet exem. plalre qul sont peut-etre uniques du point de vue bibliographlque, qui peuvent modifler une image reproduite, ou qul peuvent exiger une modification dans la méthode normale de filmage sont Indiqués cl-cessous.

Coloured pages / Pages de couleur

Pages damaged/ Pages endommagées

Pages restored and/or laminated/

Pages restaurées eVou pelliculées

Pages discoloured, stalned or foxed /

Pages décolorées, tachetées ou

Pages detached/Pages délaché:

\section{Showthrough / Transparence}

Quality of print varies /

Qualité Inégale de l'Impression

Includes supplementary material/

Comprend du matériel supplémentalie

Pages wholly or partlally obscured by errata slips, tissues, etc., have been relilmed to ensure the best possible Image / Les pages totalement ou partiellement obscurcies par un feuillet d’errata, une pelure, elc., ont été filmées à nouveau de façon à obtenir la meilleure Image possible.

Opposing pages with varylng colouration or discolourations are filmed twice to ensure the best possible Image / Les pages s'opposant ayant des colorations variables ou des décoloratlons sont tilmées deux fois alin d'obtenlr la meilleure Image. possible.

Thls ltem is filmed at the raduction ralio checked below I

Ce document est filmo au taux de ifduction indlquil ci-dessous.

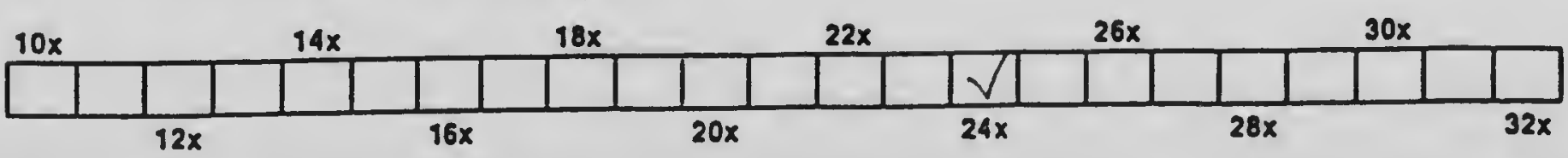


The copy filmed hare hes been reproduced thanks to the generosity of:

$$
\text { Toronto Reference Library }
$$

The images appearing here are the beat quality possibie conaidering the condition and iegibility of the orlginai copy and in keoping with the fiiming contrect specifleations.

Originai copies in printed papar covers are fllmed beginning with the front cover and ending on the last page with a printed or lilluatruted impres. sion, or the back cover when appropriate. Ali other originai copies are filmed beginning on the firat page with a printed or illustrated Impression, and ending on the last page with a printed or lilustrated impresaion.

The last recorded frame on each microfiche shell contain the eymboi $\rightarrow$ Imeening "CON. TINUED"I, or the symbol $\nabla$ (meening "END"). whichover applies.

Maps, piates, charts. otc., may be filmod et different reduction ratios. Those too iarge $t 0$ be entirair inciudad in one exposure are tilimed beginning in the upper ioft hand corner, ioft to right and top to bottom. as many frames as required. The foilowing diagrems illustrate the mothod:
L'exempiaire filmo fut reproduit grtce th góncrosits de:

Toronto Reference Library

Lee images suivantes ont bet reproduites svac lo pius grand soin. compte tanu de le condition at do is nettote do i'exemplairs fiimb, ot en conformits avec ies conditions du contrat de flimage.

Lee exemplaires originaux dont le couveriure en papier eat imprimbe sont filmbs on commençant par lo premiar plat at en terminant soit par la dernldre page qui compore une empreinte d'impresalon ou d'iliustratien, soit par is second piat. seion is cas. Tous ies autres exempleires originaux sont fiimce en commençent par le premidre page qui comporte une empreinte d'impression ou d'iliustration ot en terminant pap ie dernibre page qui comporte une taile empreinte.

Un des symboies auivents apparaitre sur lo dernibre image de cheque microfiche. selon le cas: lo symbole $\rightarrow$ signifie "A SUIVRE". is oymbole $\nabla$ signifie "Fin".

Les cartes, pienches, tabiecux, otc., pouvent dtre filimbs $\$$ des toux de puduction diffurents. Lorsque is document eat trop grend pour btre reproduit on un soul ciichs, il est fiimb d partir de i'angie supbrioup gauche. de gauche d droite. ot de haut en bas. en prenant ie nombre d'images ndesesaire. Lee diagrammes suivents iiiustrent is mothode.
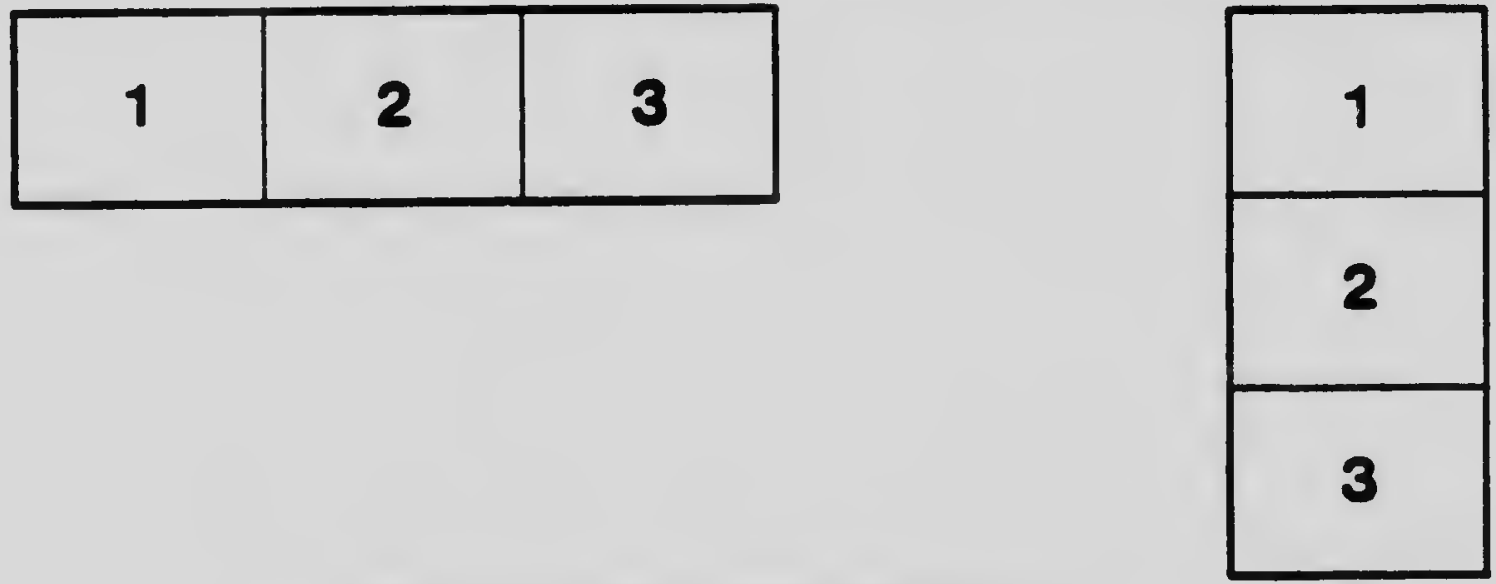

\begin{tabular}{|l|l|l|}
\hline 1 & 2 & 3 \\
\hline 4 & 5 & 6 \\
\hline
\end{tabular}


Sapplinunt No. I, to the Thirty-Fourth Innual Keport of the Department of Marine and Fisheries

$$
\text { FIルIIEIITS }
$$

\section{SPECIAL REP()R'TS}

o.

I.- The Hatchiner and Plantiur of 'T'out.

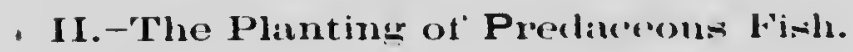

III. The Aim and Method of Firluery Iderimlation.

PROIIESSOR E. E. PRINCIE, I.R.S. CiNm,

Dominion Commiswioner of Fisheries.

\section{1}

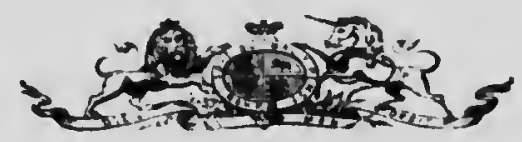

OT T A W A

PRINTEI) BY S. E. DAWSON, PKINTHK TO THE KING'S MOST EACELLENT MAJESTY 



\section{SPECIAL REPORT'S}

\section{CON'THAT'S}

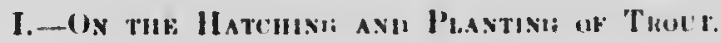

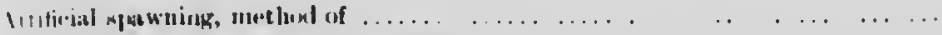

1:Ni:P.:

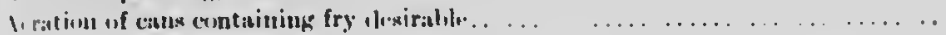

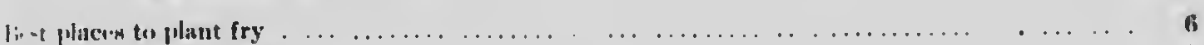

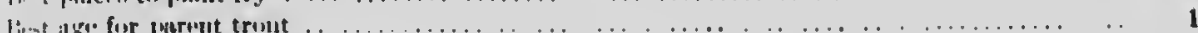

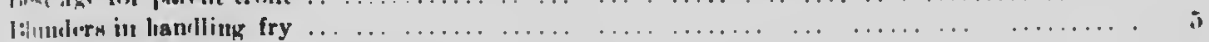

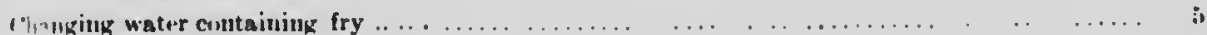

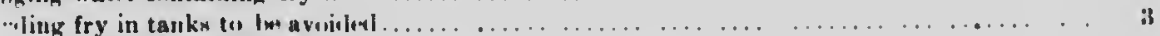

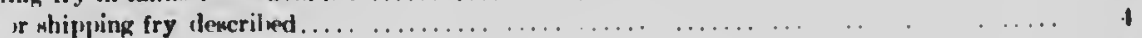

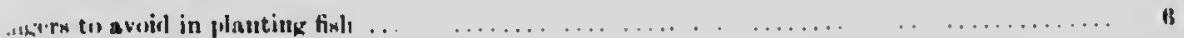

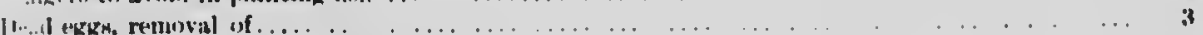

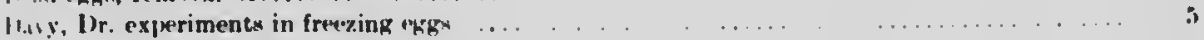

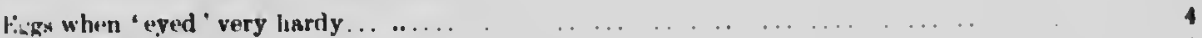

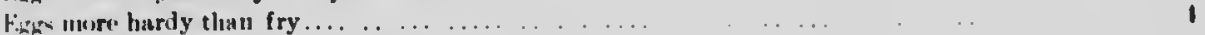

H. Inticity of timh

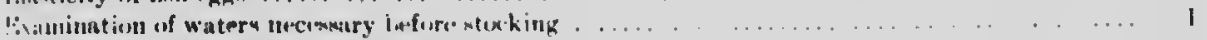

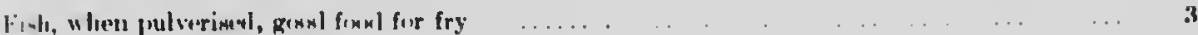

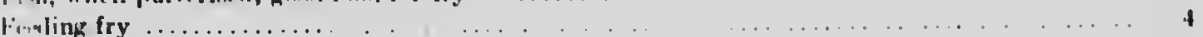

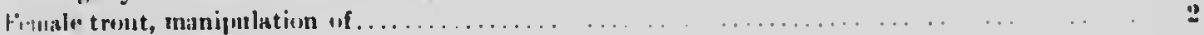

Firtiliging fisls

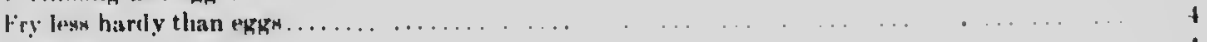

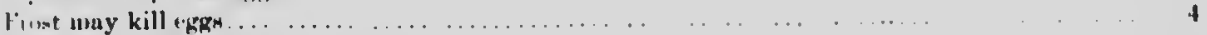

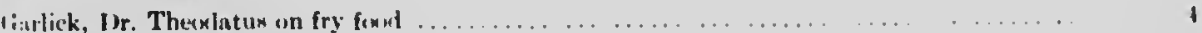

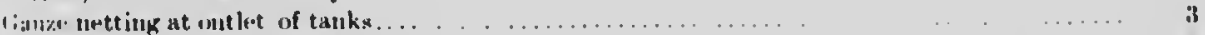

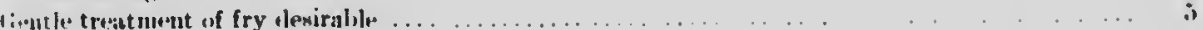

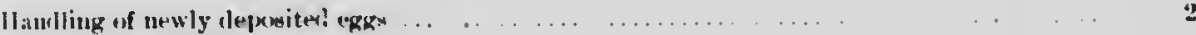

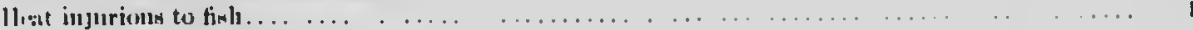

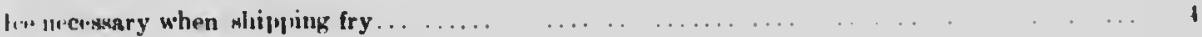

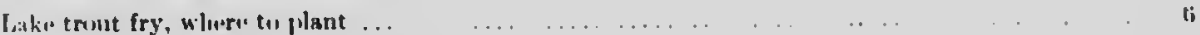

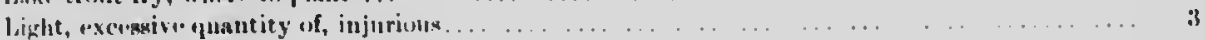

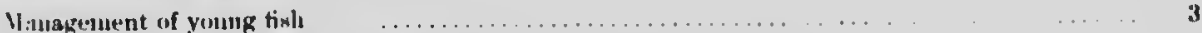

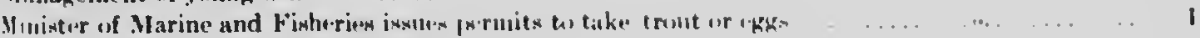

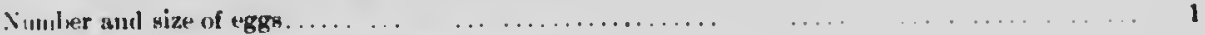

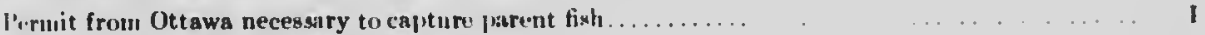

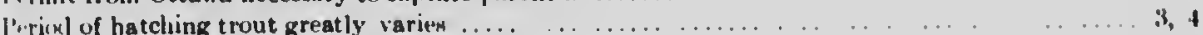

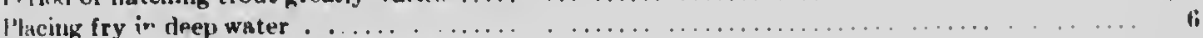

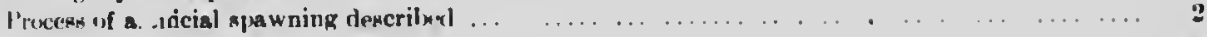

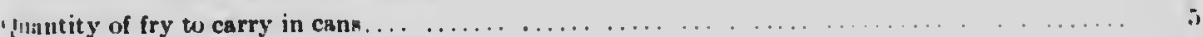

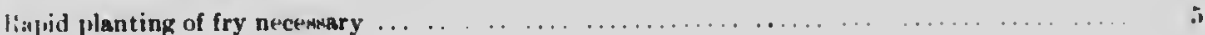

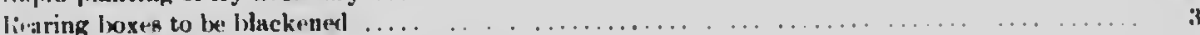

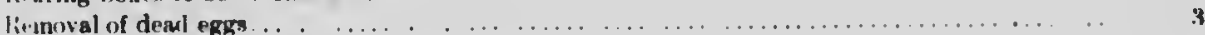

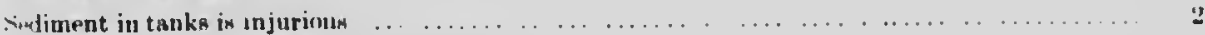

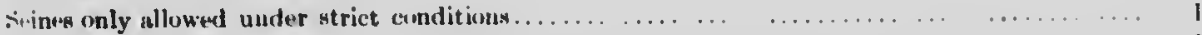

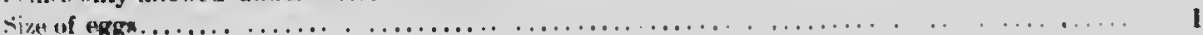


1-2 EDWARD VI1., A. iso?

Siring water prefferahlo for hatchiriw ......

Tounperature of water.

Time oxcupioul in inculmation Hul hatching

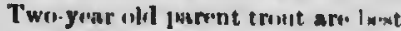

Water muply mlumlij In, funr and unfuiling.

Whitutish fry, where les flact: tlit'll.

\section{Il.-Tue Phopagation and l'bantinc; of Prebareocg fisu.}

l3aw will interminate hresk trut. . . . . . .

". " linguras wiolely.

11. 1,., 1:

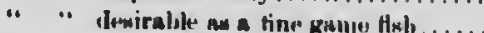

“. " lefomionl from chargen.

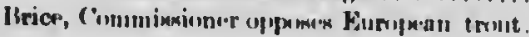

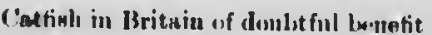

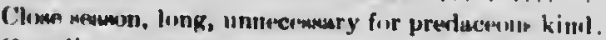

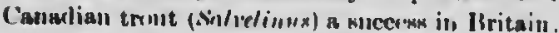

Care mereasary in transplanting tish

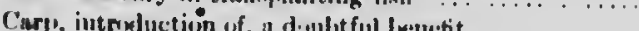

" is olrug to Canawlian tixli.run.n...

" a meriona injury to the I'otomace R., I . s.

Jangers in transplanting ur.w sprecies

Different commlitions in varions waters

19, $13,1:$

Finglislı trout uot dexiralle in onr wat

Foxeter, Maryuis of, dofends hlicek hisux.

Foorl of tmit

$$
\text { " linass ............... . . . }
$$

Fiwh reflace each ot luer in lepluter| water

I'maling killed off by tr. t

llerring of great lake . H.xwer whituriall) now valuahlu.

$$
" \text { " coxint witl pike. }
$$

Harm deme lyy injulicions planting.

llonse sparrow sll "vil on this contiuent

Inju liciurs planting

Kanwludgo exsential in intrulncing nuw sinecies

Iake-tmult conxist with whitefinl

" replace whitefisll, tiungrian Bay.

Mankin age is a dangerons squecipy

Minnows in pionty emantial for lolack hass.

Now Kealand, Fugliwh tmut in ..

Perch, amazing incrisace of, after plantiug.

" cannot le rerlucerl in numbers

" valued for sport.....................

" deatruy a truut laks.

Pike mitable only for inferior wah.r.

" killixl off Scrittish tmot and walmon.

l'ickervl or l hore sery clestructive

l'acific trmot umlesirable in eastern waterk.

Pikn-purch mupplant whitetish in Iake tiris.

Prelacerus tish over-min watwers. 
l'antuac Kiver, earp killeyl uff lawn in

r.s.:

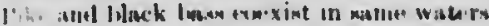

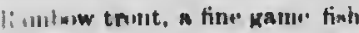

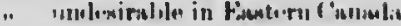

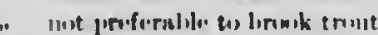

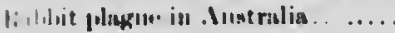

11

11

11

$x^{\prime} ! !$

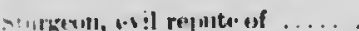

IS, I?]

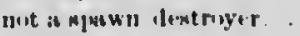

I4

wort li pritueting.

difticult to lintch ......... .

$1 ! !$

1!!

- im.m s. trulte in rivers...

1:, 1:3

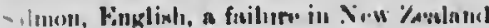

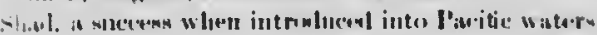

Q:in.kars.

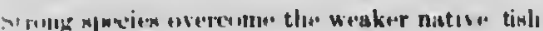

firmll net deniralle in wextern lakes

finglimh Hourixll in Sew Yealaml

elsarford in lencl, Irol, Scritland..

$x$

jorinn wal hi tientroy by dyuanute

Bronk, proferahle in Fantern Canam a

" fixid of ........

- killerl off graylinu

11 are eanniluals .

maty Ine preferalile tu mitnum

diatroyevl by laxw................

14. 15

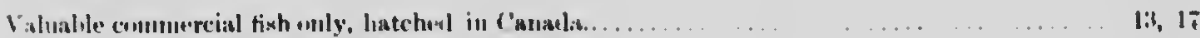

Whitetisls staterl to le prediucenes in Iake. IVinnipme......

11. 11

" revjlite sjecial protetetion...........

13. $1 !$

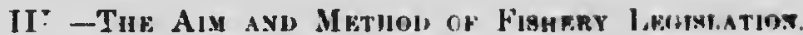

Igents and buyen of tish in contlict with fishernen

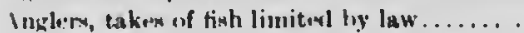

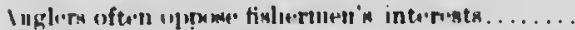

Irras se't apart for fish propugation. .

liare hosks (grajunels) for sturgeon prolilibitosl.

litwis of all fixliery leginlation in the putblic gomal....

21,2

$$
" \text { " follffold. }
$$

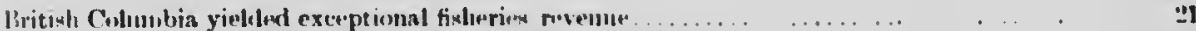

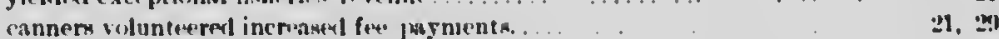

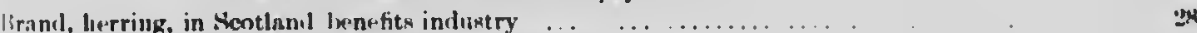

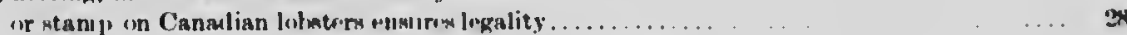

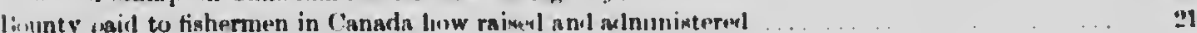

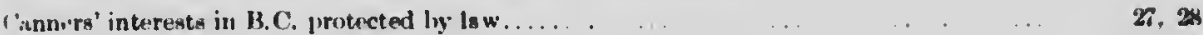

fisnner火 in B.C. granted net licenses..............

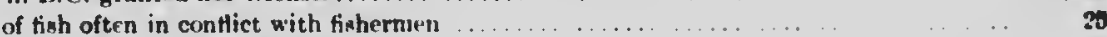

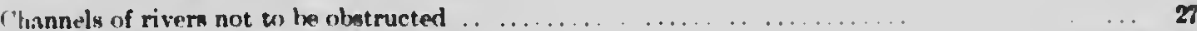

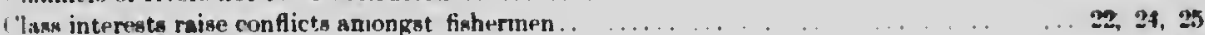

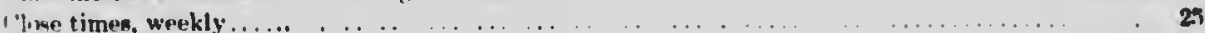

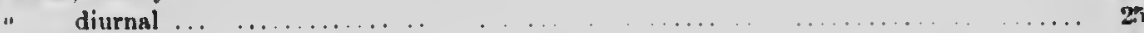

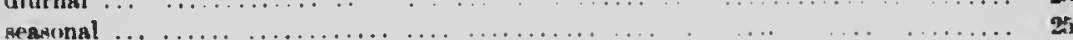

('anaclian fislery laws not designed for revenue purjusatb. . . . . . . . . . . . . 20, 21

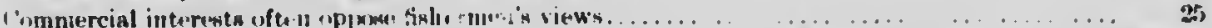

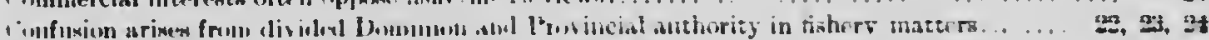

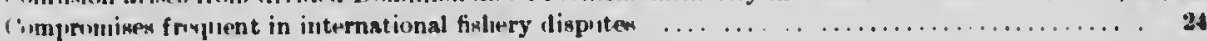

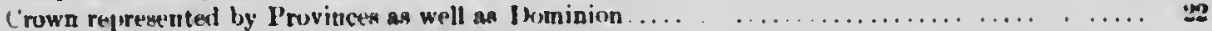




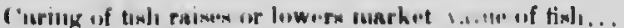

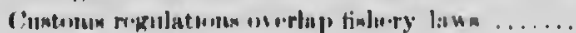

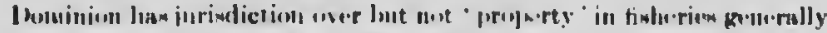

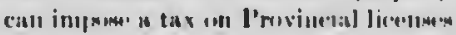

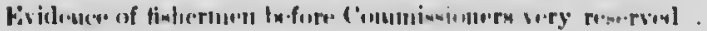

Fim, interente of, prominent in fisluery lass... ...

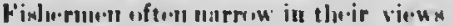

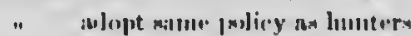

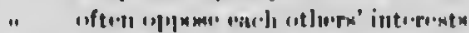

Fimlery lawe in all centric*x u gradıal grouth

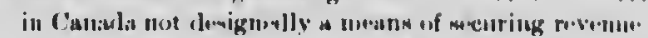
wlund, In. ]

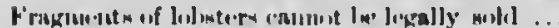

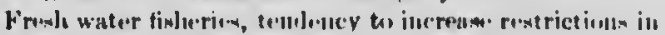

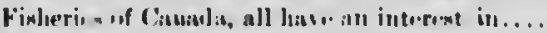

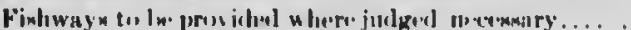

Fonrfold lamis of tivlofry levislatiou

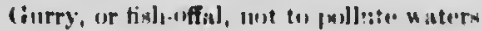

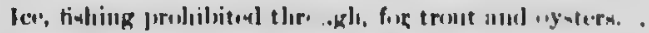

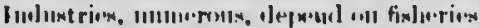

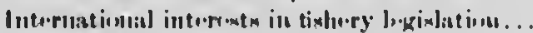

$\cdots$

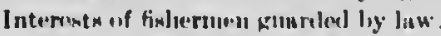

$$
\begin{aligned}
& \text { " "tivh } \\
& \text { 11 Intions } \\
& \text { 1. state tum a whul. }
\end{aligned}
$$

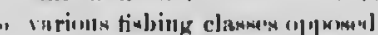

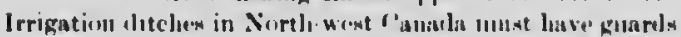

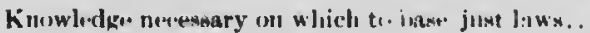

Jawful texcilap regarlink winte of tinll .....

Iaเหm, fin]lery, are fourfold in tlovir oloject.

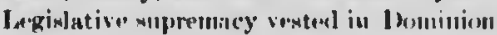

I, аниек, fis]li:ry, rofo.rmad to.

L. .

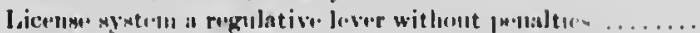

$$
\text { " " afforla effretive conitrol. }
$$

Ialustor wize liunit in bay of Fundy waters decieled fy market

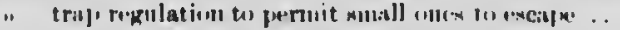

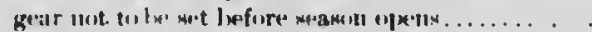

$$
\begin{aligned}
& \text { 1. ataul) or hrand guarantou's (puality. }
\end{aligned}
$$

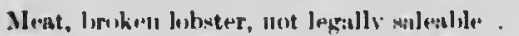

Mes] of mots s/neritiod in cortinill rogulations . . . . . . . . . .

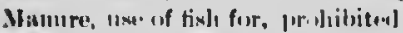

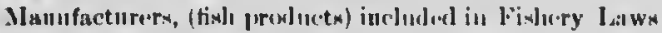

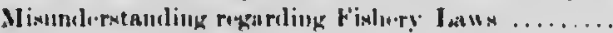

Migratiou of tisls facilitated ly Ia

Moral sumion effective in tishery protection.

Nets, distance betweell, lecgally mpecitiexi....

" lengtli of .

" of cortain kinds juolibiterl ... ..

Vational interests iu fisheries conserved. .

Jorwoyian driad arings best prices...

Obntacless to fist ...egration i]logal.... .

(Overtisluing firevented ly law

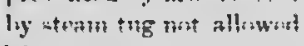

(Offal prohilition...............

(b)ster minimum logal sim of

1 Irexlges forbiditeı ........ 


\section{SESSIONAL PAPER No. 22b}

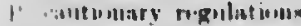

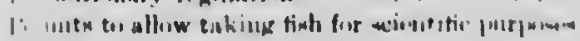

I Inisus in ris.r., se. . .

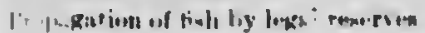

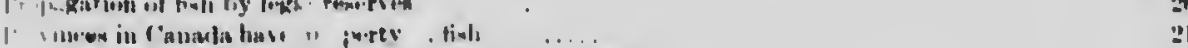

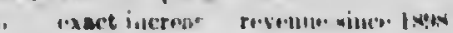

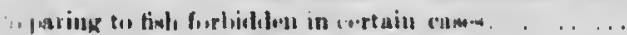

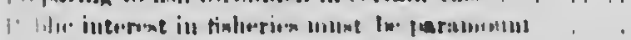

-

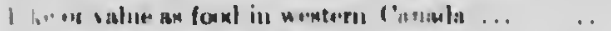

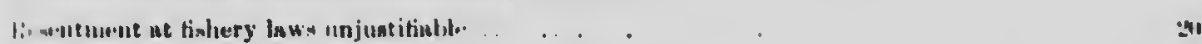

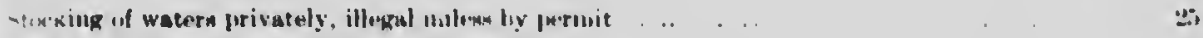

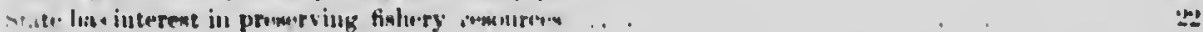

fintials law, enrly un finloerien. ... ... . . .

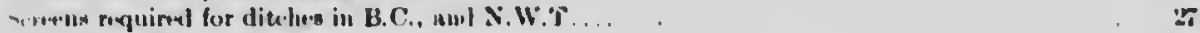

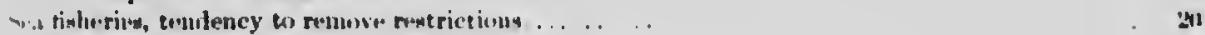

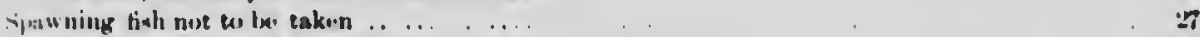

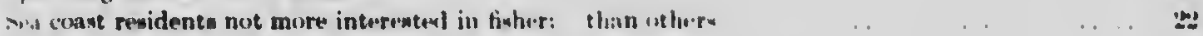

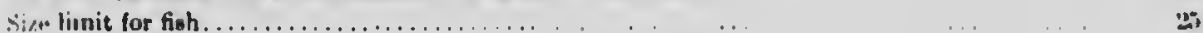

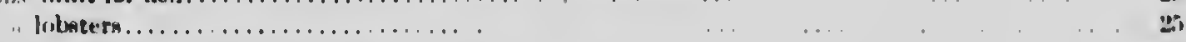

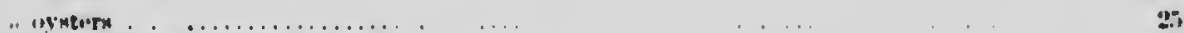

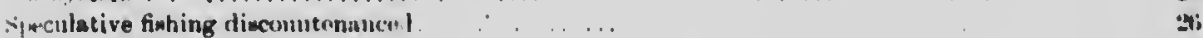

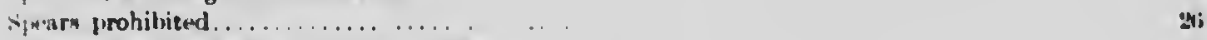

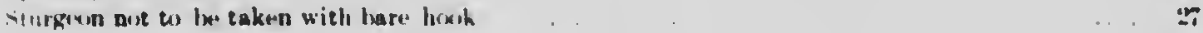

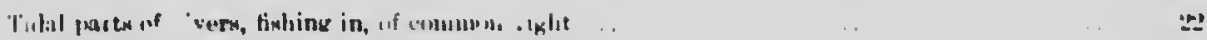

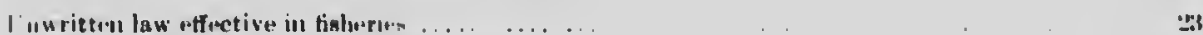

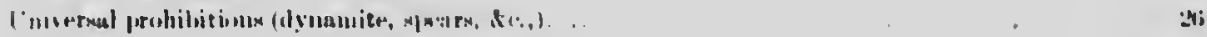

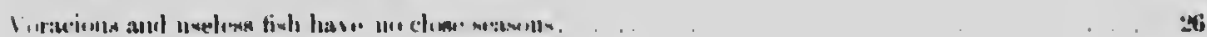

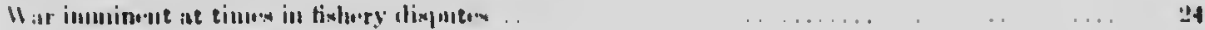

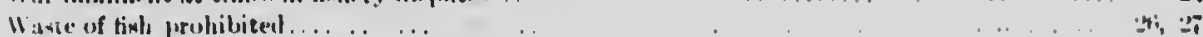




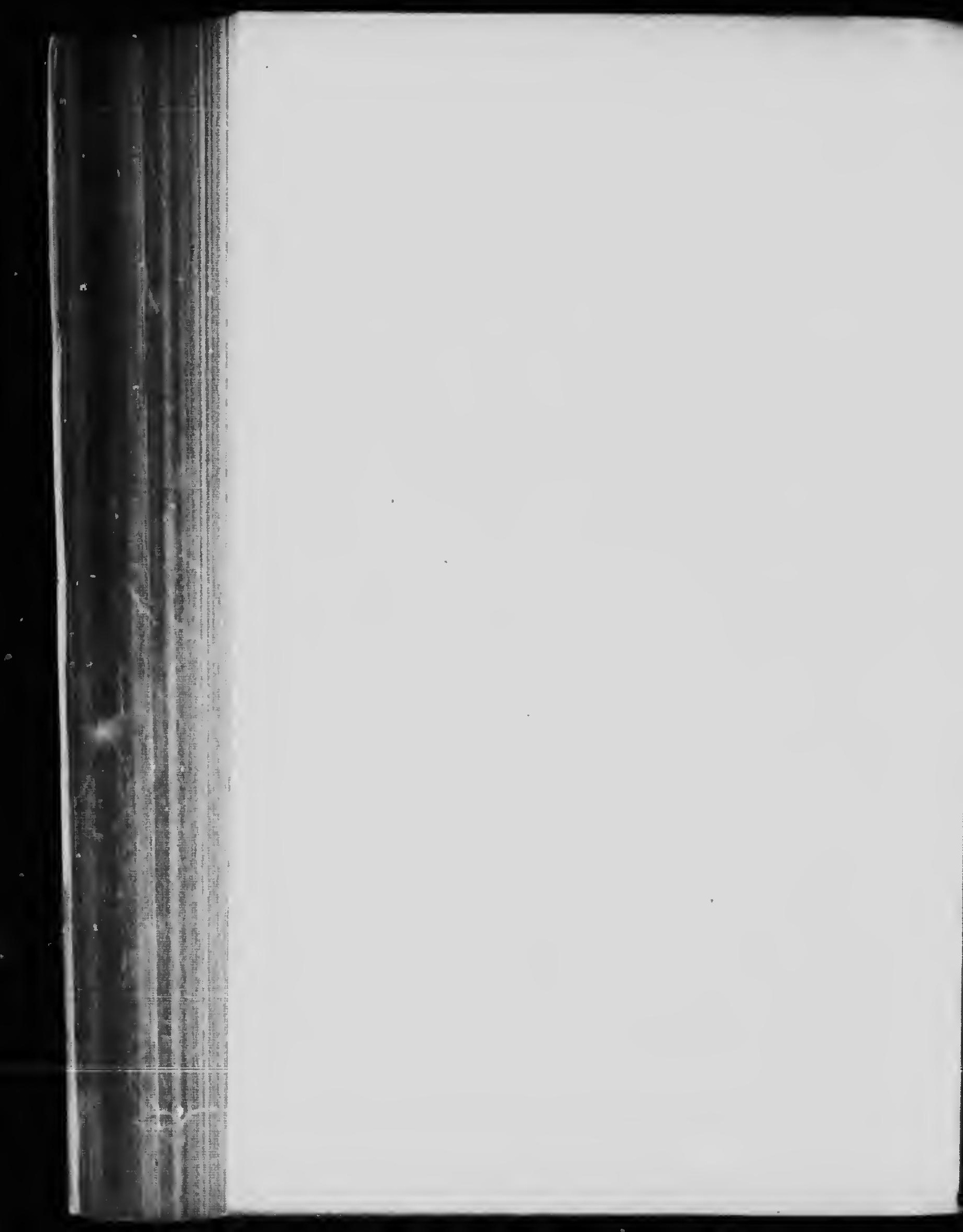




\title{
SPECIAL REPORTS.
}

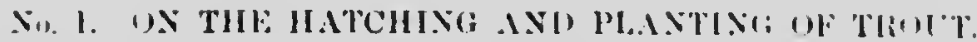

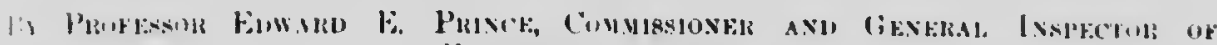 \\ Fistr.liks ron Cisamb.
}

In the hatching c trcit and salmon, whose ovn are tomparativoly large and litisy, is usual to place the engs in vhallow perforated trays ovel which pure tiesh wate'

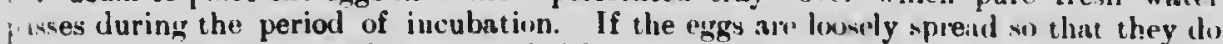

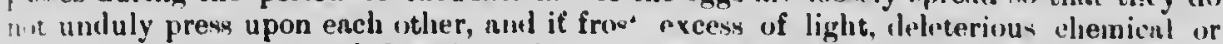

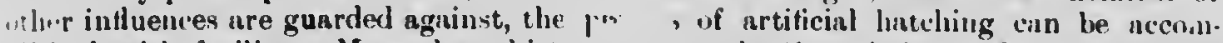
Mislıed with facility. Nore than thirty ve', sho the Commissioner of I rish Fisheries histched a puantity of salnon by a simple incubiting aplaratus in his oftice in tho linstons House, Dublin-a elear prof that the obstacles to success are not rerious.

liefore commencing nrtiticial fisliculture for the purpose of stocking any watr.r., it is necessary $w$ prove as $n$ first. step this the waters ure suitalit. Fiven strems mad laki's, which once abounled with trout, my, duriug the process of denletion, have

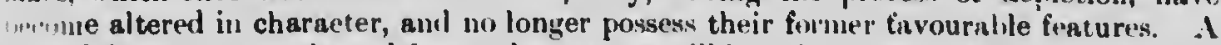
ten adult trout transplanted from other waters will in a single season afforil the repuire! intormution. If the fish survive and flourish, therr need the ut fenr of sutcess. Such information is esperially neessary in the case of artiticial pouds of of waters which it is f'rposed to stock for the first tinie. Under conditions which are really unfavouralsle -peckled trout will, of course, live, but not in a henlthy, vigureus state. "They will even -urvive in shallow stagnant water, where the supply is wnill and uncertain, but very ilfferent conditions are necessary for successful trout-culture.

If it is intended to hatch and resr trout from the egrg, the parent fi-li must loe veured before the clove season begins and retuined in $n$ puml until ripe, uth:rwise irout can only be secured by olsaining from the Miniater of Marine and Fisheries a pecial permit, the conditions attiched to which are vor stringent. Trum, when "wo years old, will yiald spawn, but as the number of egg "yialderl by them is sulali, and the eggs have heen proverl to he less hardy than those uf oller fish, it is pro" ierable to select parent fish not younger than four years and unt olier than twolve:

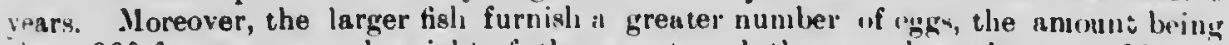
about 900 for every pound weight of the parent, and the egas themistres are of larder ive. A salmon produees eggs at least one-thiril larger than thoso of a small arilue, aud the $\mathrm{fly}$ hatched trom eggs of large size have heen foumd to be tiur, healthier, and of more rapid growth than from smaller egge. This is ws the alu of trout. Ilie

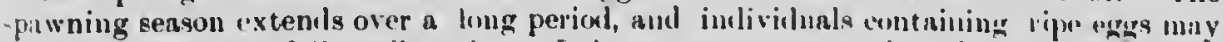
i.. found from late full until spring. It is mot neeesiary to ilescriln: th. methods of

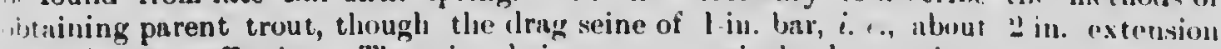
mest, is rery effective. The seine bring an "xcessively dostructive net is g("nerally

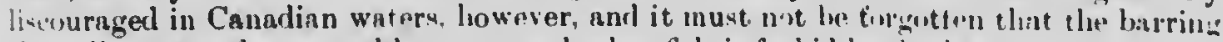
1. small strenns trequented by trout nud other fish is forbidilen by law.

The refuisite number of parent truut having leen obtnined and contines in atuall

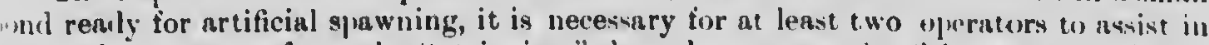

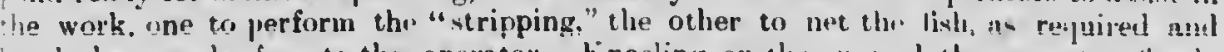

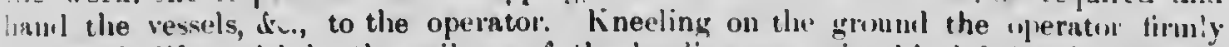
at gently lifts a tisl by the tuil ont of the lambing net, nving lis left hand mul irevts s? $s$ hend for $n$ inoment on a towol, lightly pussing his right hanil towiris the thront n+1

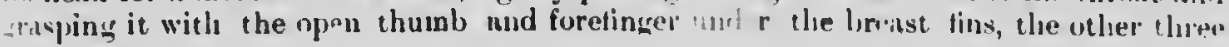


fingers of the right hand being pressed upon the left gill-cowr of the tivh. The bat $k$ of the tish is presmed againt the right bre ist of the operator and the tail bent back and upward. If the fish is fully ripn, the ripe egges will shoot out in a continuous strants and the assistant completes the operation hy gently pressing upon th. undes side if the fish anl passing his land from the head tuwards the tail to expet the "gga that: may not hav run out. The egg- should not fall far, so that the assistant should lin. ur place on the ieft of the operatir the shatlow dish, which is to receive the egs's. $D$. . force is necessa'y. It the egg rufuve to stream out, the tish is most probably not cull: ripe, and a litth patience will prcre that. Some fish refuse for a minute or two to vintil their spann, and ohl fisl alwais spawn less freely than young examples. Some inan: pu'ators wrap the tish in a towel, leaving the snout and hind part of the body frew. others hold the fish's head or shouliers in the left hand, and grasp the under side it the borly with the right hand, holling the tail down and shightly pressing with the. right thumb. There are disadiantages comnected with these methods : but in all aliti. patience and gentle handling are essential. The tish should not be unduly disturly. or roughly treated, and spawning :an thus be accomplished without the slightint possibility of injury. Very large and strong fish may demand the uniter eflorts of $t w$. operators. Whel four or five female fiv have been spawned into the plate yiehlinz. say, 10,000 ova, the assistant must then land in succession two or three ripe male. Fiach tish whould be brought cluse to the eags as they lie in the plate, and as som in the alxhomen touches the egga a large tlow of creany inilt will be forcilily ejected. 'Th, plate. snould be turned round as each new mate is brought so that all the eggs ma: receive a share of the thuid milt. A slight pressure of the right thumb and tins"r behind the hreast tins and further back will increase the flow. The milt of a sinn! mule will suttice for an extraordinary number of eggs if both sexes be in fully ripe ant dition, and in case of necessity one male nay with confidence be used t. fertilize libe ova of tive ". sis fimates : but where possible the fist named proportion is safest. "Tlie vivifying or fertilization of the egg will be aided by gently stirring them with il featber after milting, ind adding half a pint of water to dilute the creany milt. $i_{1}$ dislt when thus filled and stirred should be placed on one side and five more fentiti, -pawned into another dish. In half an hour they should be transferred to a lirger ver..., it cle in woulen bucket, and placed uncker a gentle flow of clean water, to wash impurities and exress of milt away. The enge will appear mo longer soft and yiehlin: and instead of clinging together will be hard to the touch and separate from ench ot liev. They are very watic ind will endure great jressure. Thus Frank Buckland, the min-t famous of ringlish pisciculturists plicerl upon sume trout eggs a weight not less thit tive pounds six ounces befure he could crubl, them. Nevertheless pressure esjun.i.t. upon newly fertilized cags is highly injurious.

It is necessary to place he eggs, after lyeing cleaned, upon the hatcling trit

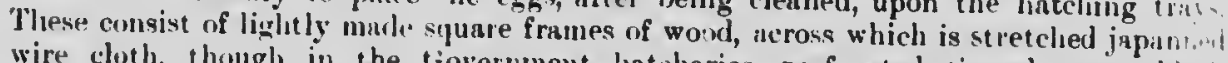

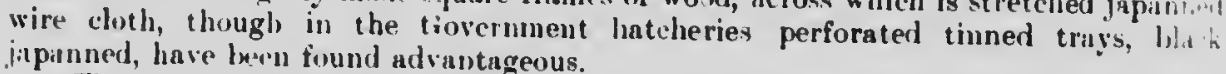

The following fir. conditions are necessary for successul hatching :-

(1) I supply' of water which is regular and unfailing.

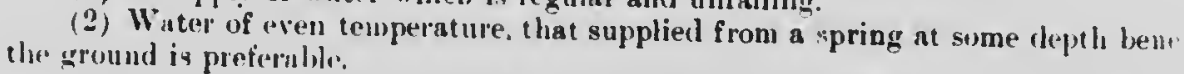

(3) Freethn from inpurities and sediment, which sufficate the eggs, henc* supply of water should run into a tals to allow sedinent to setche lefore it runs
the hillolning trils.

(4) The yuintity desirable is ainut 100 gallons per hour for 10,000 eggs. greater th" quantity of water the betier, as eygs actually breathe water and i: ainj?'t supplies of oxygen which the fresh intlow of water contains.

(5) Protection from tlonds by means of guards and an overtow ditcl higher than the supply pipe. While sping wation from its equable tempirmente, purity other teatures is alway preteriblele, yet when incubation has advanced to what ic iall. the ered.egg stage. watej from a browk or river will serve quite wefl.

Truut eggs hatch out in from 50 to 150 days, arcorling to the temperatu? annunt, and ripidity. $n$ well as the character, of the water. ifater from limeste. 


\section{¿ESSIONAL PAPER NO. 22b}

rinta is generally hell to be best. and the greater the yuantity of wnter the longer can cubation be protracted. Temperature is of courss most potent, and a clumare of onfe

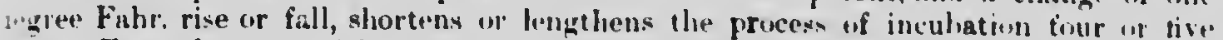
ind. Fges of trout which latch out in $\$ 0$ days when the temperature of the watel is

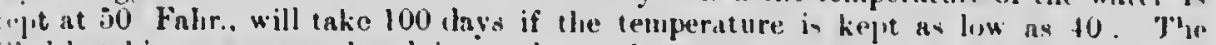
tilled hat ching trays are placed in womlen tanks open at the top, and a thow of water throught the lroves must be nrranged to ell-ure (wo) inches orr less of water orer the eggs.

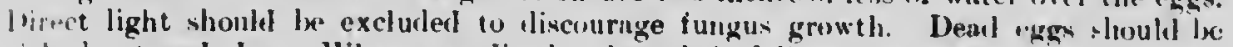
ficked out each day. When eggs die they luse their delicate transparency aul houm, inl insunie a dead white apparance, and unless removel a feathery fungus rapidly weis the egg, anl spreads to other henltly ergs. Hene tine necessity fur prumptly emsing them. If egs require moving on the tray it sloulel be done gently with a it cuncel-hair pencil or brush. They may be sutily swept intu a upmon when it is dreirid to remove a few from the tray. A tray may he enptied by lifting it ont it the water and skilfully overturning it into al disli. Figgs mut anser be turclied be the land, and dend egegs are leot removel with womlen pincer's or forceps.

Hatching and rearing boxes require to be blackenel inside. Charring is much to, in preferred to black varnish. Black paint mu-t be avoided. Hot 'buck of iron :on

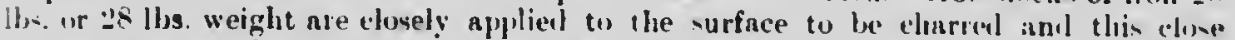
contact prevents burning. dil bexcs, trays, dec, nfter chatring, varnishing. dec, must 1.e wrll sensoned in water some time lo fore liatching uperntions ingin.

When the delicate young fry, called "alerins," "leevin to hatch they do so in such tumber that special tanks are necessary to which to crunser thew. Many of the fry

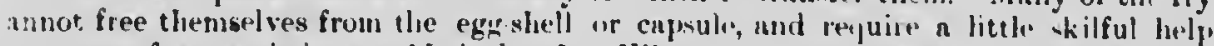
by means of an nrtivi's camel-hair brush. When not more than two hrours whl the lithle fish hase intelligence enough to dart awy from danger. It re'tuires some agility is capture one with a spron. A sconp of tine gauze or preforated zinc is etlective.

The following points uny be noted in connection with managing the fry:-

(1) They should he exposed to very little liglit.

(2) So food is required until the large bag of golk attacherl to rnch alevin is ainost absorbed.

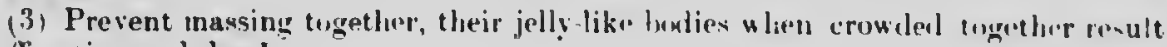
in suffucation and deatls.

(f) Cover the exit with tine gatuze to prevent the tail and yolk anc of whe of the try passing t!rough, and necasionally sweep thell gatsty ciwn from the point of uttlow.

linfore the yolk is gome. trout fry will pick up minute particles of fonl, numl, inderd,

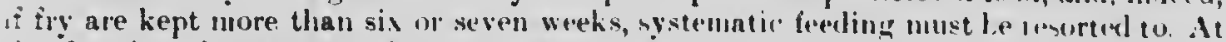

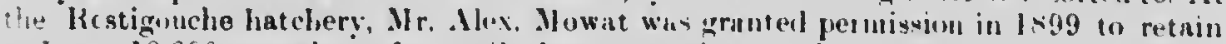
wh rear 10.000 sen saluon fry until they wete six montlis old, when many of thent

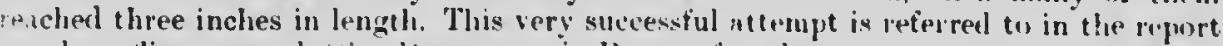

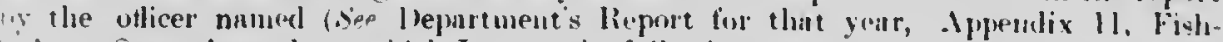
' ilture Operitions) troun whicli I quote the following :-

As regards the 10,000 fry retaned at the hatebry in opun air lank untii six

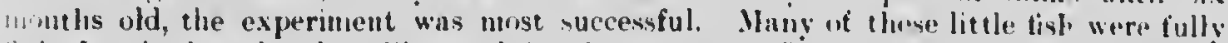

inches in length when liberateal in the nutumn. The form tor the fry comsists it

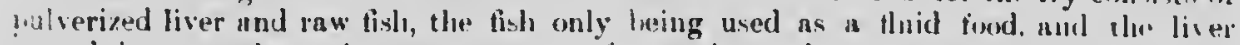
irnted intu powiler. A great mount of attention and care munt attenl the work of fwoling the fry, and keeping all dead and decaved matter removed fron the tanks. I am contident that from the trial male during the pist summer at the bes. side linteliery, time large numbers of the fry cau be fed and resred in the tanks for at leist -ix montlis l, wi, re lieing libernted.

The utility of using uther tish, in a powtered or masherl -inte for the suatename of aivanced firy wis suggested long agoly that pirneer in tislt culture on this continent, Dr. "The, ditus Garlick, of Cleveland, (Ohio, C.s.A." Dr. Ciarlick, in lis interesting little

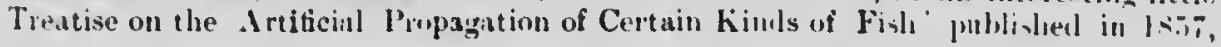

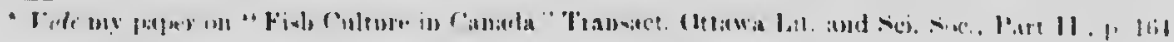
$2 ! 3-11$ 
said (p. N4.): It las been ascertained that the lean tlesh of animals, when boiich, is an excellent article of foorl for young tisl, or even old ones. Is the fish are very small. :is recessary to hash it up into :ery tine particles or they will swallow it : in tact. . $^{-}$ slinuld br. Founded or grated very tine, but as they incrense in size, it may be given in coarser particles. The flesh of other kinds of fishes, where they are plenty, would be $a ! 1$ excellent sulistitute for the flesl of animals, either cooked or uncooked : I think thikinil of food preferable to any r.iher.

The question has often leen cliscussed whether fry whose incubation has been protracted are stronger than those which have been liatchell earlier under a lighn.'. teuperature. Certainly the mortility in liroods of English trout hatched in water below $40^{\circ} \mathrm{F}$. is far less than when the water is of a higher temperature. Tlie sank. has been found to he true of the Canadian speckled trout and the Rainhow trout.

In a series of ova which had reached an alvanced stage in water of $+w^{2} F_{\text {, an }}$ were then placed in trays supplied with water $10^{\circ}$ lower, the hatching out dirl nut tah. place until tlic 1:-0th day, though thry are known to hatch in 50 or 60 days uncler higher tensperature. The resulting try are more robust, and fewer die cluring the early stages after lileration from the egr than in those hatchiel at a temperature of II 60 . Actual tests on spawning beds have shown that for long periods the water mily not rise above $34^{\circ}$ or $3 .^{\circ}$ until April, and the period of hatching is therefore proleng. to 150 or 160 days, with the result that the fry are stronger and more healthy.

In accordance with the conditions which obtain in rature, the fry, wfter exclusinn from the egg, should not be subjected to very low temperatures, but water rangi?:fron $45^{\circ}$ to $55^{\circ}$ is most suitable. The carrying of fry to the localities where they an. to be deposited is an importint matter. Kailway joumeys, if not too protracted. i! little harm to fry, unless the cans or tunks holding them are kept too near a stove " hot pipes. Excessive heat often proves fatal in riilway cirs, but as a rule, journevs by rail are less perilous than by twun ver rough roads, when the shocks and collivini. seriously disarrange the delicate organization of the young fry, and damage it is heliesm. the sensitive otocysts of the little fish. Team-drives over rough trails through for are not conducive to the well-being of fry, and when possible, cans slould le carried. $i$ the manner described later, over very rocky or uneven tracts. Conveyance by lowit. canoe is by far the best mole. Cans specilily contrivell for the purpose are bert, an. should be made of leavy galvanized iront or stout iron well tinned, and holling lig 12 gallons of water. They may ixe 24 or 26 inches high, and say 18 inches in diantet. but may be of the form of a truncated cone, with a narrow neck in the centre for the purpose of preventing the splashing and loss of water as far as possible. Into the ne (say 6 inches in liameter), a cylindrical cin fits, the lottom of which is made of fin. metal gauze. The gauze not only allows of airation, liut when necessary serves :receptacle for pieces of ice, which, melting, trickles into the water below in which fisl, are $\mathrm{s}$ imming about. The ice is often broken up into tine pieces or crushed, it loes not melt and cool the water properly. It should always be remembered that young tishes, above all salmonoid fisles, cannot endure heat, nor are they able withstand frost with impunitv. Indeed, ice placed in the lid of the can or tank hasproved larmful when on warm days the fry liave been surrounded for some liours by water of $50^{\circ}$ or $60^{\prime}$. Hence the arlvisability or transporting young fisl either in carly spring imonths or during the niglte, and at early imorning when the seasun warmer and more ad ianced. It such times thry con be most safely shipped.

it is well known that newly hatched fish are far less laarly than egg". But ant eges during the first few weeks are very sensitive. and within three weeks after ferti

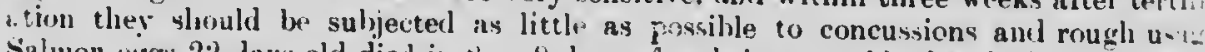
Salmon eggs $2: 2$ days old died in s or 9 days nfter being roughly handled during :... "xperiments iy the late Dr. Francis Day, the well known British salmon authorit but after the $4 i$ tl day only very liurtful 'ause's, such als chenical inpurities, de., do then any harm, and "eyed" "ys are hardy in the extreme. No doubt "il numbrs of ova are lont every year at the heal water's of salmon rivers ly being tros'n

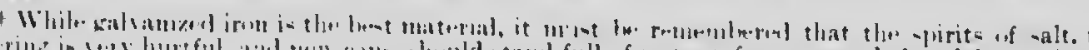

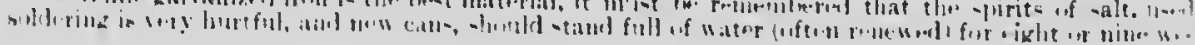




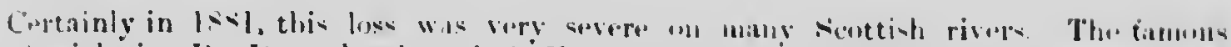

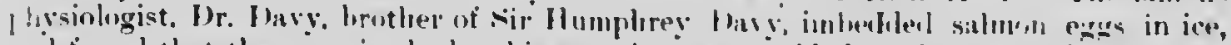

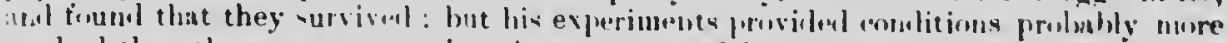

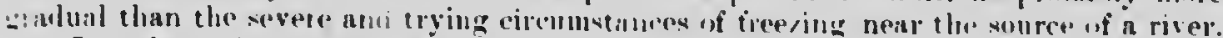

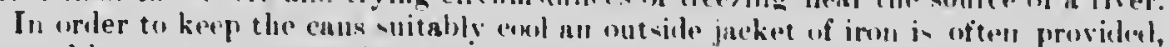

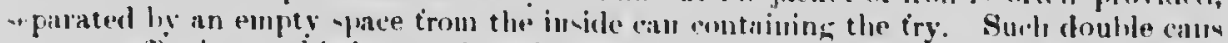
an sery effective. and heing much romler than urdinary cins. the fry are shippot in

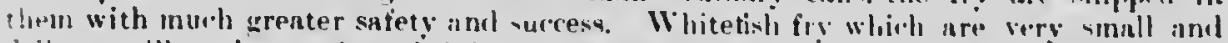

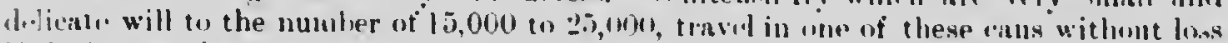
it the journey be not long and trying : but half that quantity of hrowk trout amol sabmon

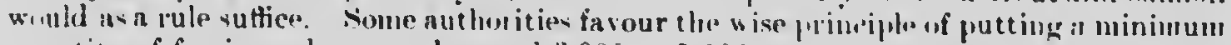

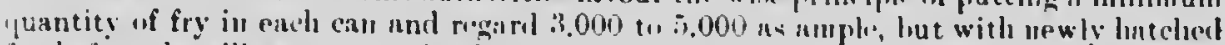

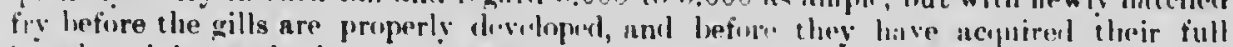
laval activity and vigour, a grenter nunbel can In safily shipped in ench rau. Ten

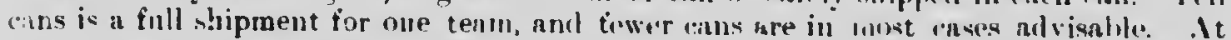

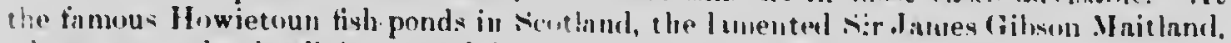

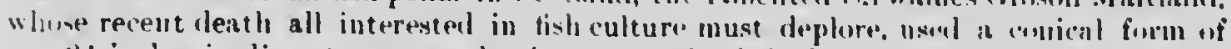

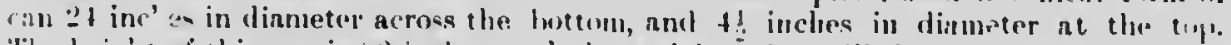

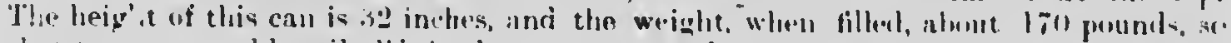
tlat twa m.n could easily lite it about ly menus of two strong handlos tixerl at points a ittle alove the centre of grasty (alsut 11 inclies from the bottoll). IIlien it in

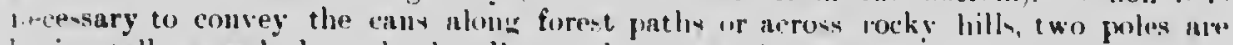

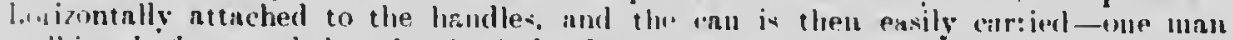

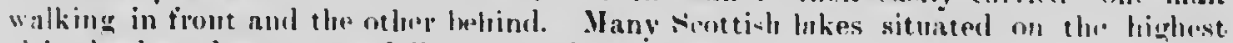
:! titules have been successfully stockial by this metliml

All fry should be plantod inumeliately after arival. If the lour of atrival at the fitnting ground la midnight or suring the math hours of the morning so much the

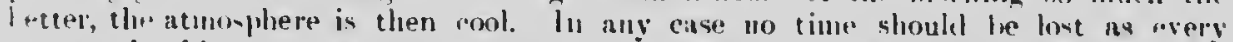

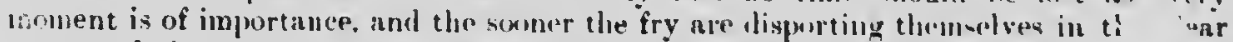

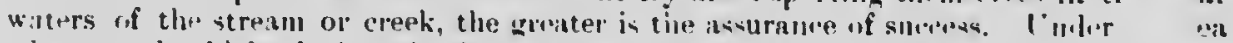
what.ver slould frv he kept in the canswer thr night. lirat risk is run ly ." iew

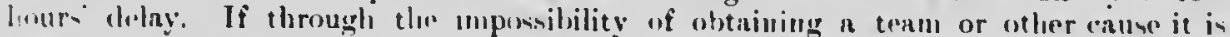
: imolutely impraticable to at unce plant thein, they shoulal ix. constantly wateh il and iesh water splaslied iu, or the water aerated by a bellows or other means. Acration is

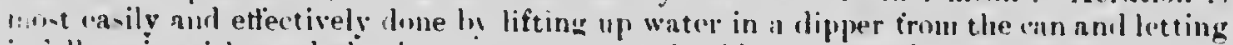

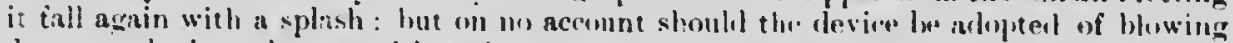

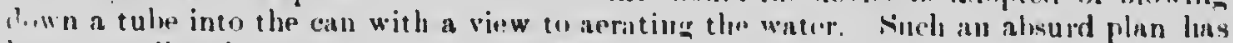
law actual!y arlopted hy some manipulators: but in hiowing alıwn poisonıuv air from

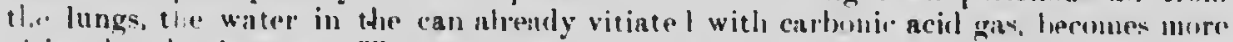
vitiated and poisosums. The surest way of killing and a-phyxiating fi-h vuffring frum lack of oxyeren is to blow air fiom the inouth into thoir midst.

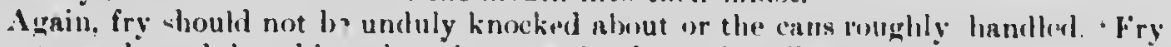

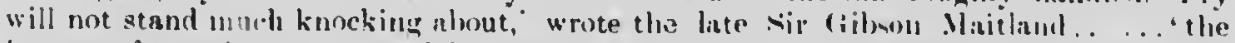

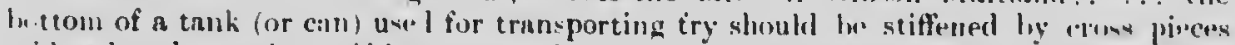

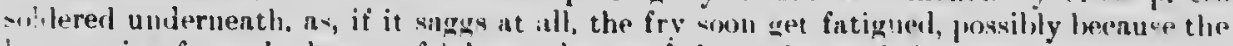

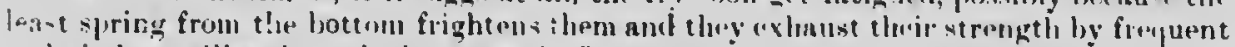
and aimless sallies through the water.' Thu same inthor alan Wr.t.: : With enre fry can lae carried for twoty-four hours, but the result is not satisfactory if the jourupy be. lulientr.

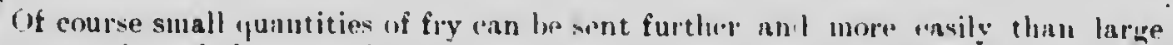
The re-aterution of the water is a diticulty. It camme be lume antomatically, as is the are $w^{\circ}$ tentlings, hecause the motion the water acpuires tires ont the fry if very

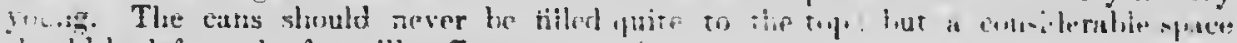
sliruld he left or tlue fry will suffocate.

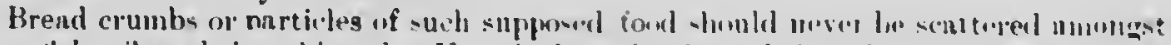

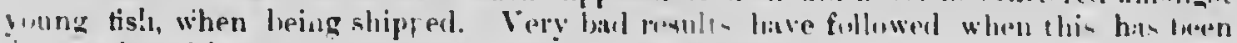
tone as hreal is a mos: unmatural form for yumg tialies. 
It usually sutices in a long jourrey to change the water at appropriate intervais The fuct is well known that little salinon and trout, only 2 or 3 week: ild, aretisal, wave theil pectoral tins to and fro and thus crente a current of water which ails i oxygena in, and facilitates the breathing operations of the tish.

The actual planting of the try is a most important matter, and a guml deal of very inappropriate active $h$ is been published upon this matter.

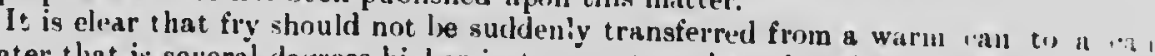
of water that is several degrees hisher in temperature than the lake or itrean.

The tomperature shoula be somewhat equalized by iningling the two wiler, bet, the tish are enptied out. The temperatue of the water into which the try all ${ }^{\prime}$ i.. transterre I would not be mole then $t^{\prime}$ higher or lower than the wat in which thw: have bern carried troun the liatchery.

It is hardly necessary to sny tlat if fry are being sent some di-tance to , planted, it is an adrantage to have all nrrangements tor tleir roception male befur. haml, so that telms may be waiting the arrival of the ciss and an immedia e var. be malle. Hefore placing the cans on the team it is achable to remove the ice irrn. the covers of the cars unless the outsile atmosplero be very warm. Cans of tivh shuid never stand in the lot rays of the sun : but a covel or sheet should be s" plared as : shie!d them. (ans shoulil also be thoroughly rinsed and cooled with water hefore ir: are placed in them. Fish frequently hecome sick before lenviug the hatchery becaus.. this rule has not been olserved and tle fry placed in cans which have been warmeri by
the sun or nearness to a stove.

It is a goxl principle to tind out where the fish naturally spawn in the water to 1. plantel, of if no tish of the snme species occur, to ascertain wier. the be-t natural con lition exi.t. Thus whitetish should alway: be planted on claten gravilly ground fairly shallow wate", or where reets of himeyejub rocks extend. Brook inut in? salmon should be pheed nest the head of striams or as far up tributaries of large rive:
as possible, avoiding, lowever, thase which dry up during the smmm 1 .

Lake trout do best if distributed over rocky shonls sich as are selected by the pu!...? tivh. In such places as those specitied there is alsundance of shelter, and the small ti-i, as a rule, make at once tor niches in the rocks, or the protection of pel,blus and stone-

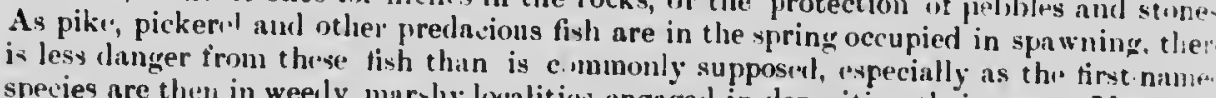

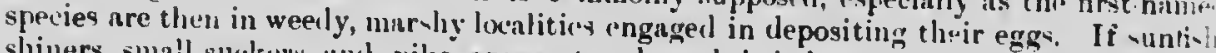
shiners, small suckers and pike appear to abound, it is best to select somi otber ar.'s

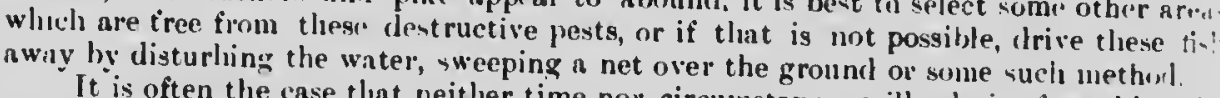

It is often the case that neither time nor circumstances will adonit of renching 1$]$ best and most appropriate localities, and the plauting must be done where it is appar. $r$. the young fry would not hate haen under natural ronditions tount. After much "xy" rience with young fry, I am bound to confess that planting fry uprin what hal II. nppear the most suituble grounds results in better success thon might have been aintici? ated. The charge ot ten made against otticials of nerely dumping in the fry at the .... convenient ratler than the most suitable places is less grave than night le inagineil the inexperienced. I nan standing on shore, with one foot elleased in a tivlesuat boot, in the water. cin prour the fry gently into a deep part near the edire, and the ir. will immediatesly neak shelter. A better plan is to gently empty the try trom a hil and the fry disperse before they reach the bottom. For a few minutes the mass of ywun.

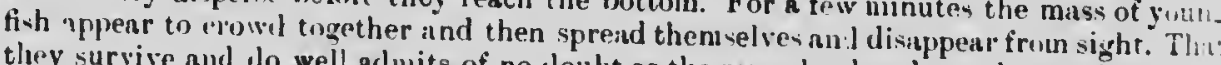
they survive and to well almits of no louht as the remark, alrendy nule, applies in thi. case, viz, that the chief enemies of the young tish are in swamy shallows enengent i lepositing their spawn. In thus favouring the planting of fry in deep water wly is a matter of difficulty to plant them in small bat.hos in sliallow witcr. I hare i

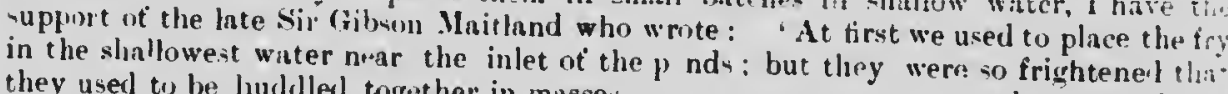
they used to be luadilled together in masses . ............ whin poureat int

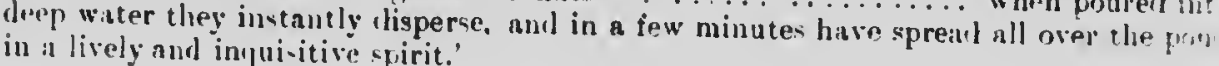




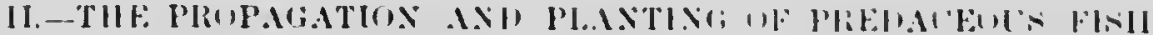

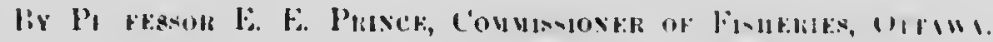

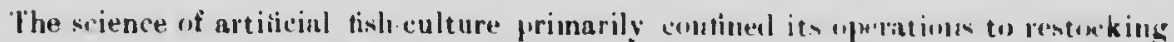

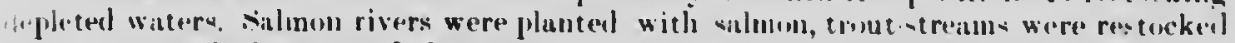
with trou, and the lirent lakes were repepplated with the yount of the lnke white. is.. There appeared to be sume guaranter that the iry distriliuted fien the hateherion would hase every ehance of survival, hecause they were placenl in watere where the cont ditions were ilpropriate. They were, in other words, platited in tho walcrs to which

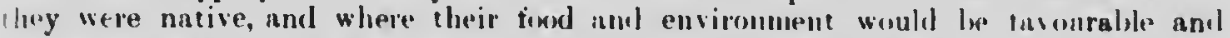

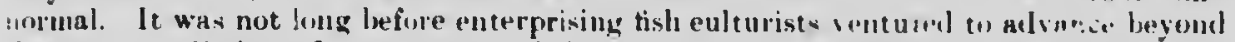
these narrow limits. It was suggesterl that yo ang fish might lee introsluced into waters

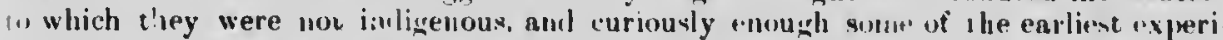

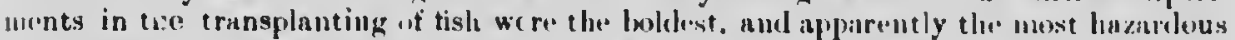

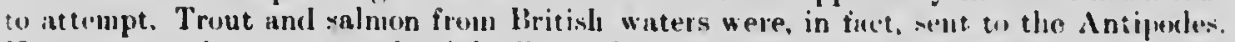
Vis trout or salmon vecurred ariginally in the rivers anil lakes of Alustralia or of New

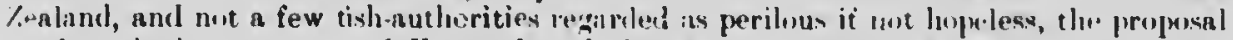

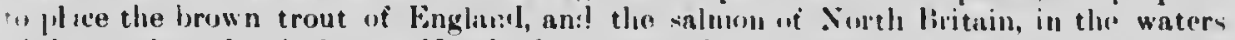
it the southern lemisphere. Senrly iorty years have pasoul -ince theser initial ship icents of liritish tish tork place anel the results are well $k \ldots$ wn. The sillwon for sonne: reason appear to lanve failet to entahlish themsselves, and the theory is that, if the young tish survived after being listriliuterl, ihey went down to the sein as smolts and nerel returned. With the trout it proved wholly different, and the success of the axprermient

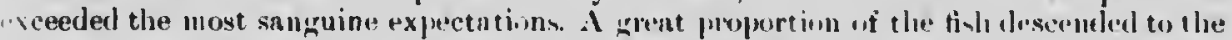
- tot and hecan:e sea-trout, hut sea-trout far surpassing theip lorethren of the nurthorn

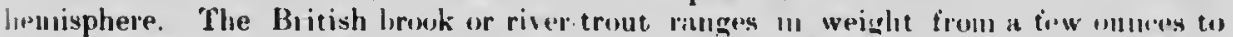

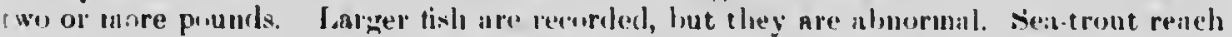

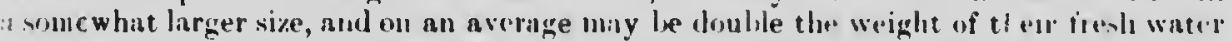

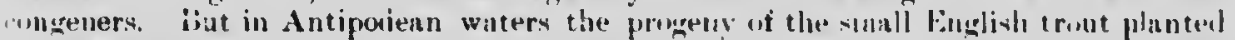
III the 'sixties' lave grown to gigantic proportion, mut huge specimens lasse

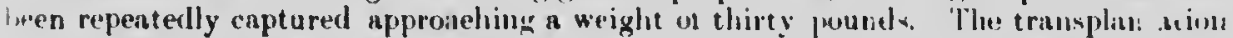

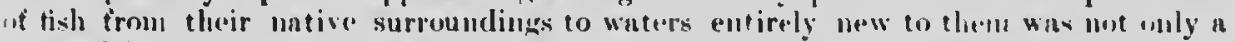

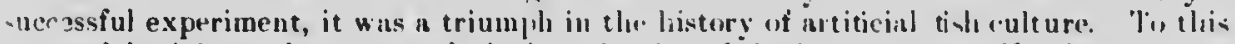
-necessful trial may be compared the intruluetion of the brook trout or Nometh . In clare of Canala and the luited states inte lingli-l and sentols waters where it has

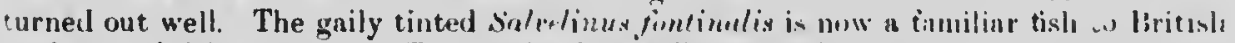
anglers and tishorulturists. The specios lans sutfered no deteriorittion by leing trans.

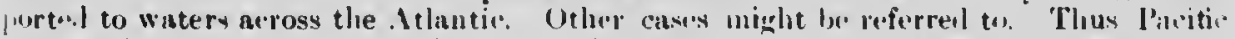

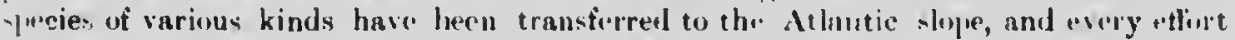
mad. to established them ther\%, while on the other hand, "Nonsise shipuents of

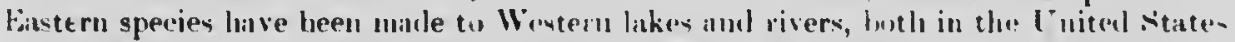

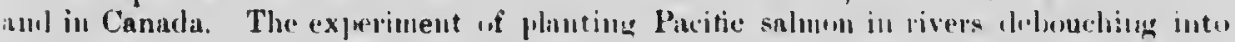

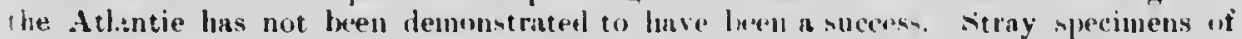

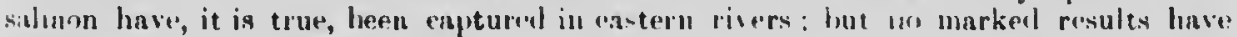

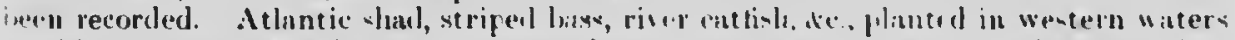

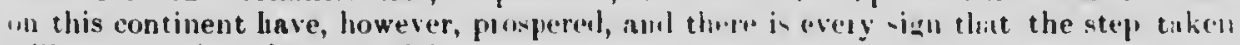
will prove eminently sucressful.

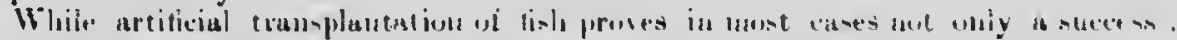
hut a very real henetit to the territuries whose waters may be stucked witl new and use.

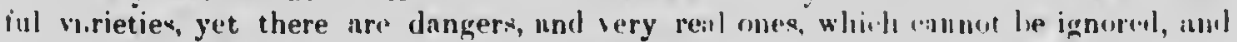
unloss some rogard be had to the safe limits, within which thi- i,ranch of ti-h cultum..

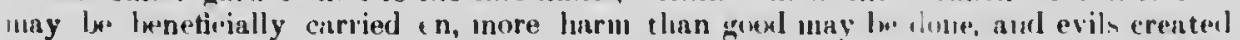
which it will be well-nigh inpussible to counterat and remuie. This "andun is sperially 


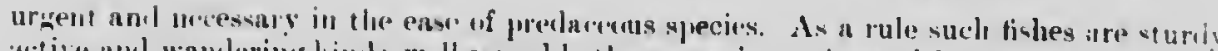

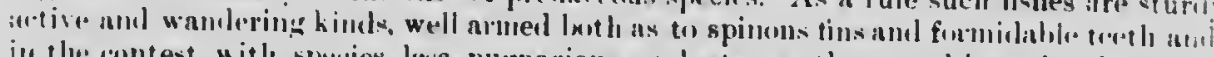
int the contest with species lors pugnacious and strong, they really anin the upp. laind, when introluced into new surroundings. I meter normal conditions in their hatis.

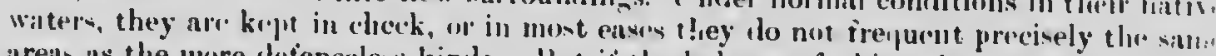

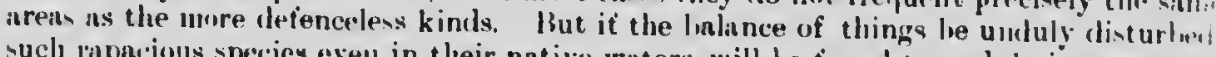
such laparious speries creel in their native waters, will I e tound to unduly incrense, ac. may over-run vast areas to the injury med, it may be, extermination of less predlanem.

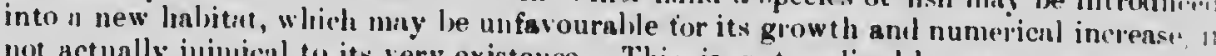
not netmally iniminal to its very existence. This is not realizal by many person, wh.

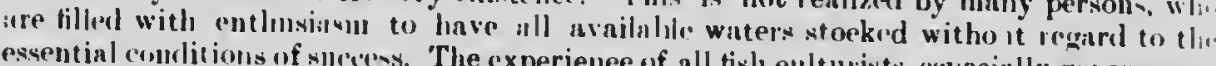

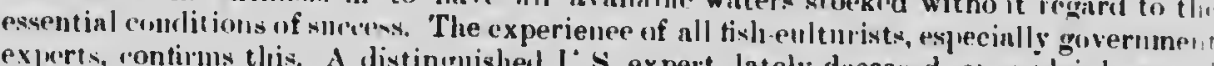

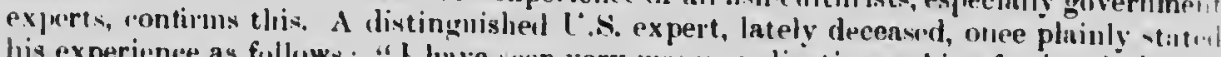
his experience as follows: "I have sen very many applications asking for hronk, hrow aud rainlow tront fry ind hrook, lorown, and minlow tromt fingerlinks, all ont the san. appliention and all desirel for the same strean or pumb. The "ternal titness of things :nut in the least considerol. I man is alvised rot to plant hrown firut in waters alrearly containing the native brosk trout, and he replies that he has already done so. I think I call point to tifty caves of this sort. There will crone a time whou some me must answiol for thi indiscriminate stocking that has been chone. That a unal avks for a certain bini

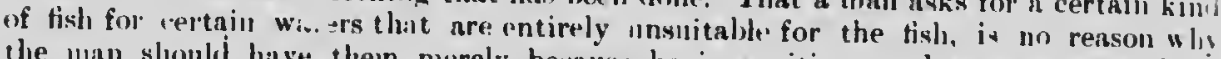
the man should have theon morely heconso he is a citizen and a taxpayer and tlic tish are free. A rhemist would not sell " man activo poison simply leceruso the man was ignorant of the results from usiog it and had heen injuesserl with the name. unil sol fincied it for his system, but al lonest chemist would recommend horelouni candy instend of the prussic acid the minn thonght he wanted. The Cormonisinit lias i lettrer on tile from a man whom application was not lilled. He said he wits entitled to th. tish and would have then or know thr renson why, with other inten lerate language. He was tuld the reason why-that 10 man was entitled to alus fish until his applieation had been pased upon lyy the counmission, then if the water.

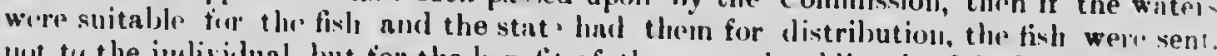
IIIt to the imlividual, hint for the lwnefit of the general pubtic who fished the water."

ln unsuitahle places where the fish do not aetunlly perish, they may he dwarferl and leal a lingering existeme. When in 188.2 a quantity of the famous Loch Leven trout were trinsferresl from their native lake, on the borders of Fifo and Kinross, in scothant. to the besutiful Ilighland lich, Loch Ard, lyy the Scottish Tront Preservation Arsociat tion, it was touml three years hiter ly. Mr. W. M. Macgregor, of (ilasgow, that speeimen wre being eaught, but their weight was not more than five ounces, whoreas thispecies of trout normally reacl, double that wright, or even twelve or fourteen ounces in the favoumble waters of I.och Lesen. Mr. Mnegregor in reporting on the matter attributed the dwarting iutluenee in Loch Ard, to the siarcity, or the difference in kint of the furd. "If comrse, it is impo-sille to foresee what results may follow the intr" duction into new waters of a strange or a forrign sprecies. The archinatization of animals (lonst, birds, and tishes) has yielderl most unexpected results in many ease. Thr inlobit plague in Australia, und Cape Colony, South Ifrica, tor instance, tlw. enormons increase of the Europenn house sparrow in North Amerien, and the result (most harnful) of the liberntion of English starlings in certain portions of the Cuitid States Repuldic, atfird sutticient warning as to the unwisdom and riskiness, not to sit? widespread ham of the trmsplanting of speciex of living creatures from their nativ. snrroundings into new arens, without adequate knowlerlge or experiencer of the posibl. lesults. Fome countrire, alive to their best interests have taken effective steps to und. and cunteract the rvil: int proventive and corrective measure should be adopted it our own and other linds. The action rf Cape Colony and Westem. Iustralia on th" question stands out in marked contrist to the apathy of other countries. Cape Colons.
in 1890 , made it mulaw ful to int roluce rablits, eitlier by land or sea, in to turn thein.
loose within the colous. lonse within the colong: rectured the rabbits already in the colony to be cr.

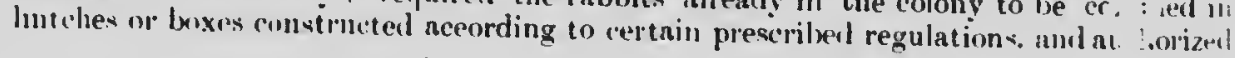




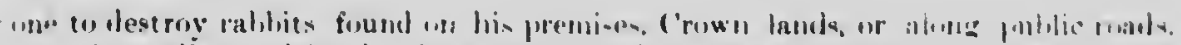

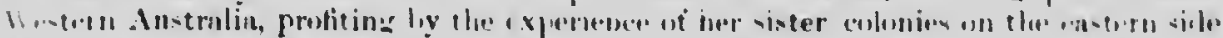

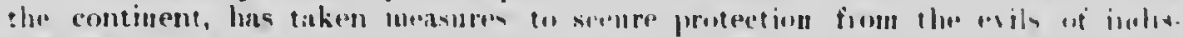

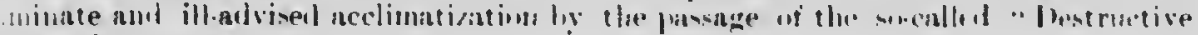
1. and animals Act."

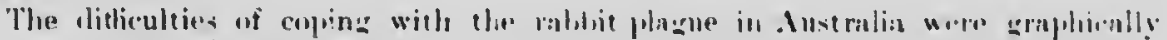

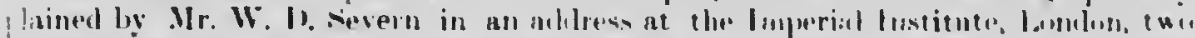

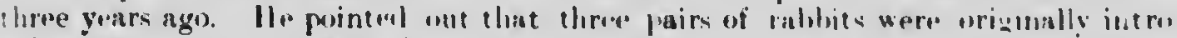

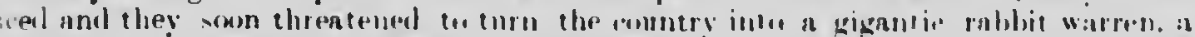

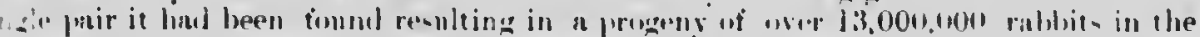

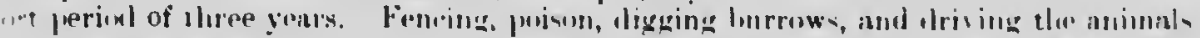

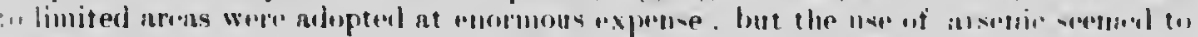

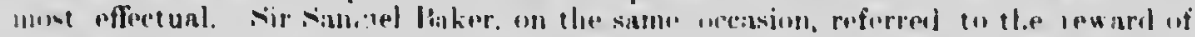

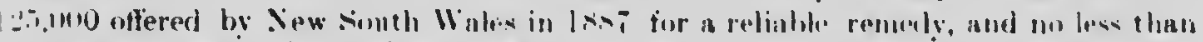

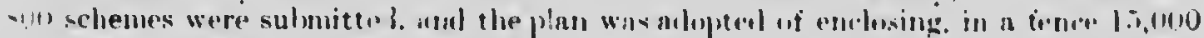
il.. long. the rablits near a supply of wator whinh way goisoned, nul they wer. w Ixing reduced in numbers.

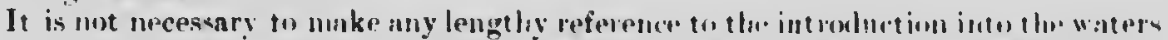

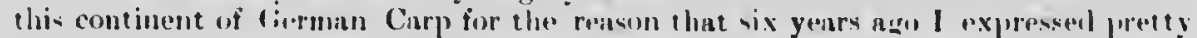

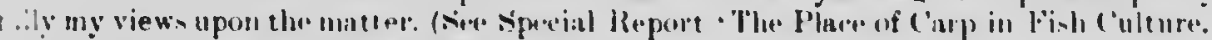
Iini. a Fish. lieport, (ttuwa, Is!mi)

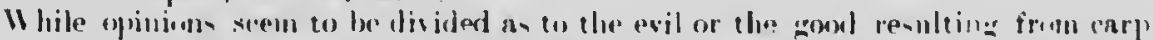

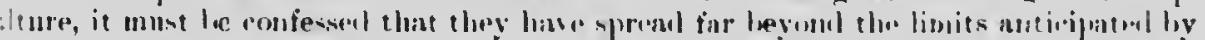

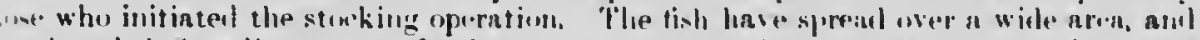

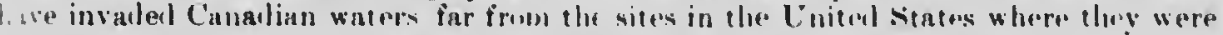

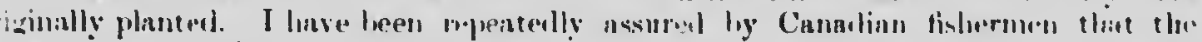

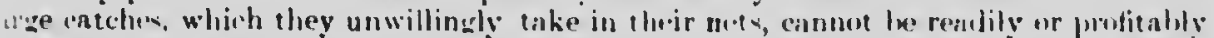

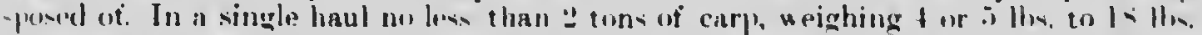

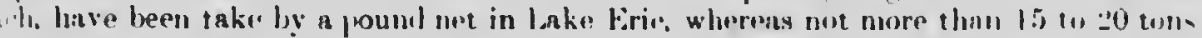

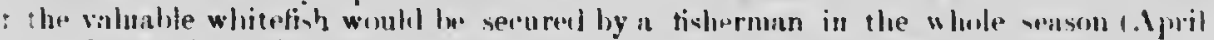
(h.tolier). The fishermen chamed that all lake firio hal been wer run hy ("irp)

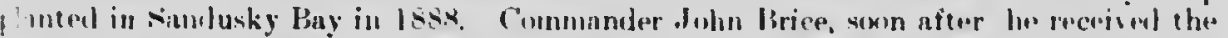

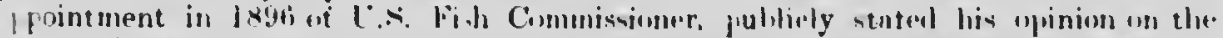

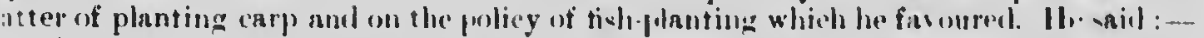

- There is no reason, elierefore, why the streims of the linted states shonhl not he

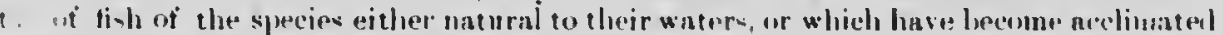

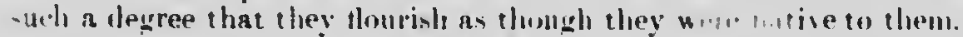

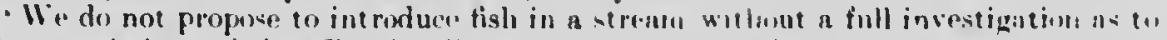

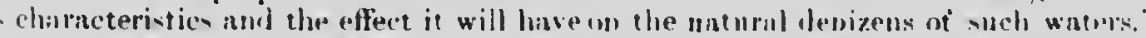

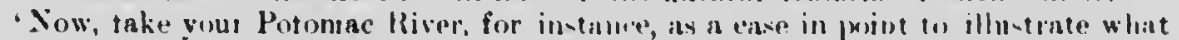

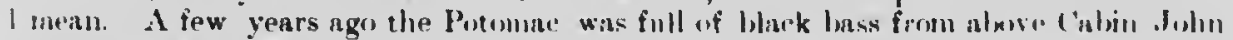
liridge to its heal witers, and fivhermen enjugel magniticent sport all alone it. Sow

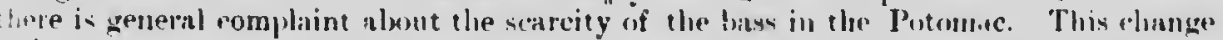

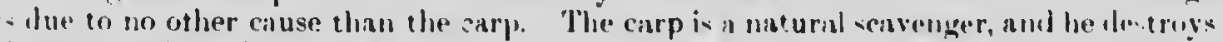

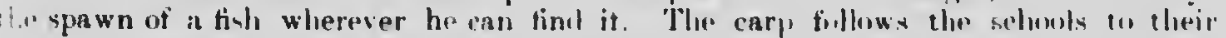
fawning besls and sucks uj nest after nest without fenr of interruption, laciture lor iv

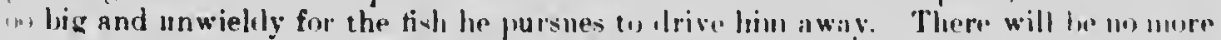

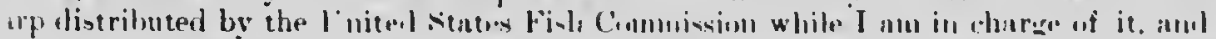

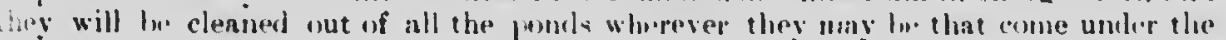
withority of this ottice

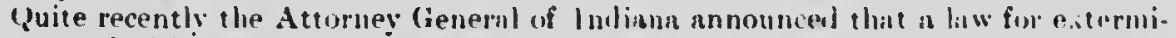

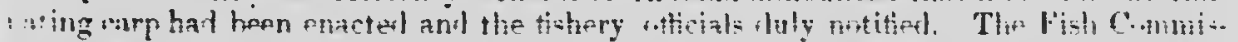
iuner asked the Attorney (ienteral if he could have the lakes in northorn Indinum

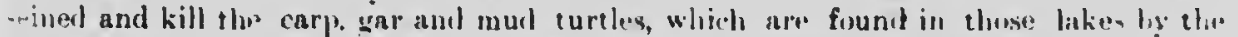
- huruands and which kill the kind of fin that the stat, dexires to funtor.

Attorney tieneral Taylor's recomnumbeim is that an immons. - winu, phishly 1."00 feet hing, he procurid and all the smaller Inkes he seined. Whet the wintes an.

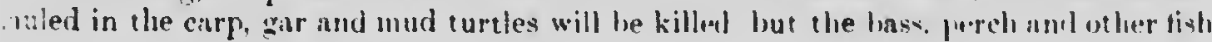


brought up in the veine will he inmediately thruwn bark in the wnter. M1. Ta! believes is will do more to preserve gine tish than my one thing that could to The Mom Kailrond Company will st ine C'edar lnke in a wort time and will kill ali

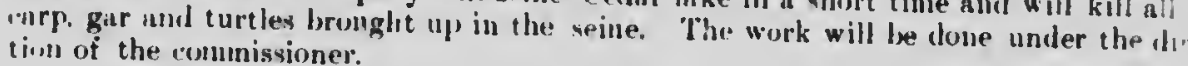

The pulicy iulopted, for " periol of many gurs in tish culture operation- in Dominion has been or wive and cantions lines. .1 woll-infornted poliry, contis. the work mainly to the hntehing und planting of almon, lake whitefish, and sreat in. trout, tha last frepuently called snlmonetrout, has beril uniformly pursuerl, aniri l'ilicy has proved hineticial and safe.

(If coure many species have been constantly prescel upull tho tioveinum attention: but most of the tish reconmended being moles or lass predacerus, - om:. them 'xtremely so, it las been felt that even at the risk of disappointing the puil. th: proplagation aud planting of these kinds wus hazarlous, and might result in inti...

There can of course be little risk in the planting of sabmon it the conditions fawurable. Is a rulı a silmon-river is not perfectly arlapted tor other tish, unl... be seatlout mnd brouk-trout, and in certmin cases sturgeon and striped buss. Cunt fresh water ling and tenge or toulndi oceur in such rivers as the sit. John liver. I...

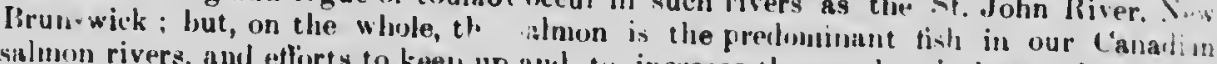
salmon rivers, aml efforts to keep up anl to incrence the supply of those noble tial tiy meats of hatcheries, nusi be un unmixed benefi it properly and succenstully crrial out. The planting of lake-whitetish fry involves no langer to other pecies. Its hati: similar uninute toon. It is stated to ehists chiol!y on small crustacenns, mollusks. iresh-water clupeoils in Lake 1 in devigur small tish, such as young gold.eyes nnusuit. There is ant oflier great-likes, lint -uch predicits and voracious is me same certainty about the great hake trout. It is a pow.r. maller tish, it planted in confium witers. teeth, and a most formiclable fik t." durini most months of tho year frejuent the deeper arat lakes of Canala, the : inslune shalluwy about apwers, and only nove into

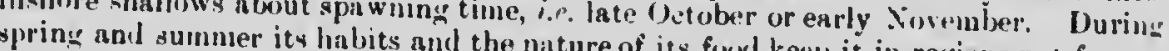
by whitefish, lience theso water generally. IBoth tishes spawn in the iall, fishes have coexisted in ('inil. taken togetlor in the same nets, the two speries at this time being more or lo... gert hike-trout. It may ahitetish do not spawn on precisely the same groumds athese fish take much ford, indee thed that during the spawning periol ueither at that tims. hence there is little danger then the stumach indicates that they proxinity of the lordes of burncions lnen to thr inollensive whitetish tron:

trout

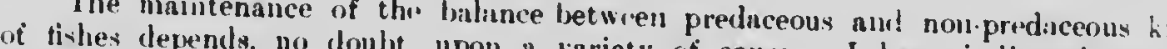
the different laibitats frepuented by variety of causes. I have indionted one, might be named. When, however, this balance is disturbed, in in the great lake.

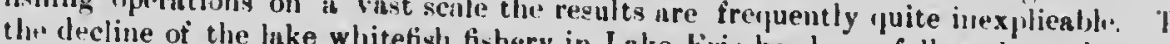
increast in such predaceous species as the in Iake Fie has been followid, not by $n$ :-1 but hy an enormons increase in as the blue and yellow pike-perch or pickerel al, speciev of interior edible yualities take's of sc.calied lake.herring or lesser whitetithe waters of Iole been ncompaned by a very apply, the diminshed supply at whitetish seems to liw In Like Ontario twent, years age tity and market value, the lesseg whitetish (called traked as of first importunce is " lake trout cane hird, followetish (called lakr herring) rankri next, anl (L. IIius) or urass jike.

Now, however, the inferior, or lesuer whitetish (so called herring) and the grans: are uf chiot market importance, the pickurel or dore ranks next, und the whitefi-h a lake-trout ar: of comparatively in-ignitiout moment. It is extremely probab!. t? 


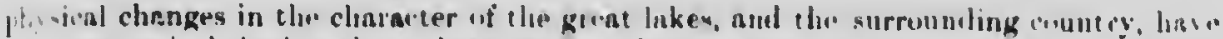
l..." phent in loringing alout these results: deforestation no deubt working vant vhan.

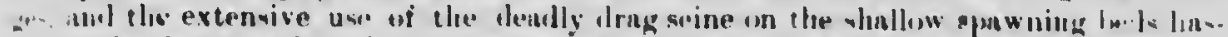

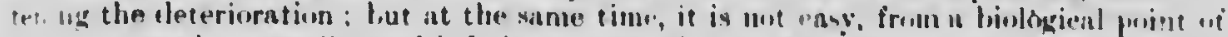
(11) -ees why a smaller and inferior vpecies of whitetish shoulal sursist, along wah

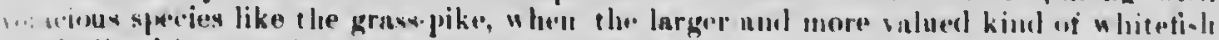

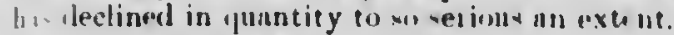

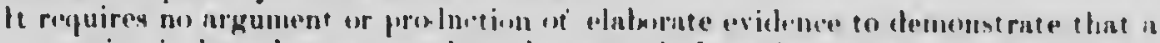

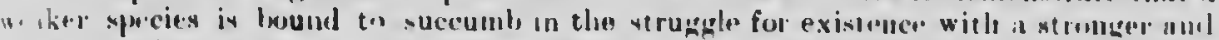

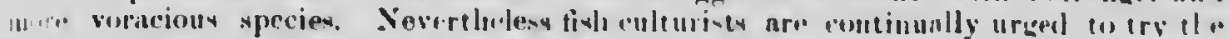

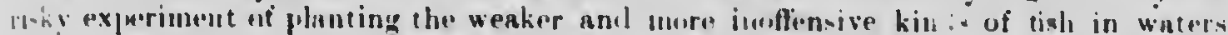

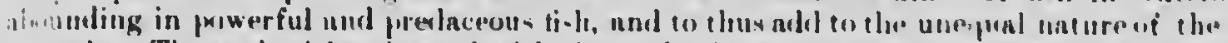

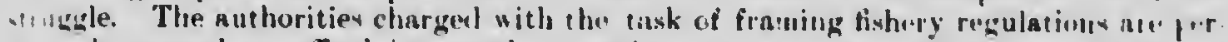

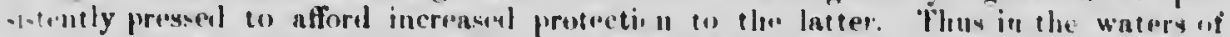

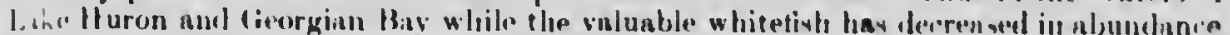

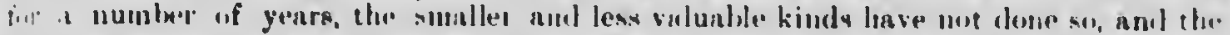

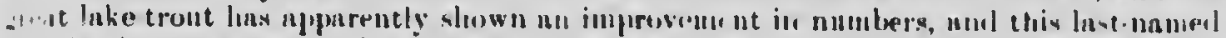

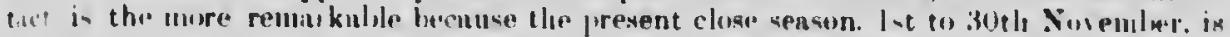

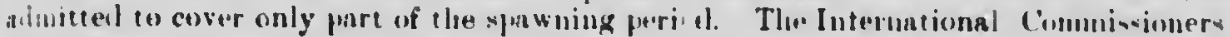

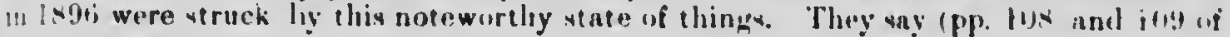
(h.ril report) :-

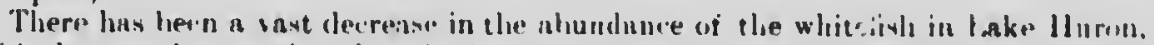

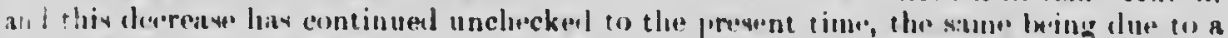

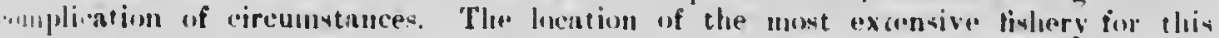

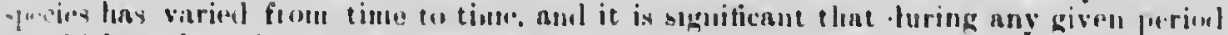

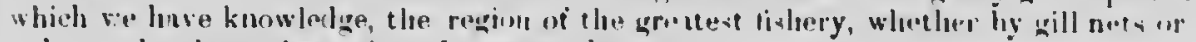

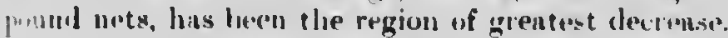

It is impossible to say whether ar uot the amount of apparatus alone, unnewn.

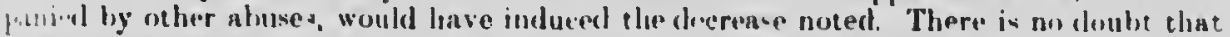

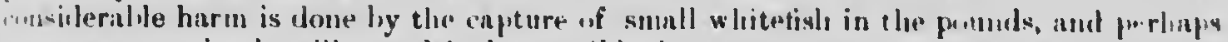

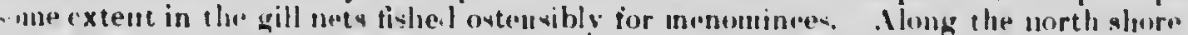
wn berth sides of the Ixoundary line the eatch of -ruall whitetish of interior value to the

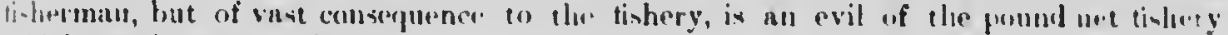
which repuires correction

- A considerable proportion of all the whituti-lo taken in the lake are canght during "pawning time, when they are close inthor and triulily ncessibir. and the fucility

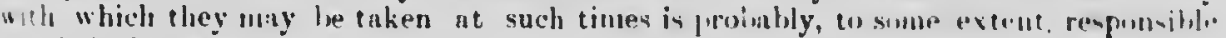
ti.t their decrease.

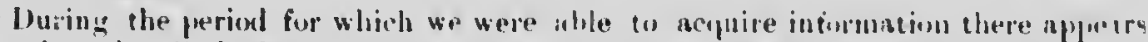

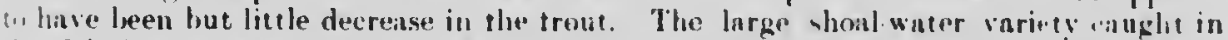
fall has apparently fallen off to som. extent, but th. oleep-watc.. furm exi-ts in

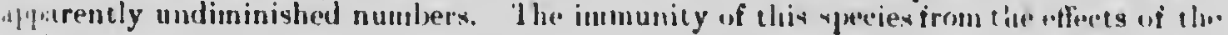
b.tious agencies which luve desimated the whitetish is, no koubt, the to its liahits and

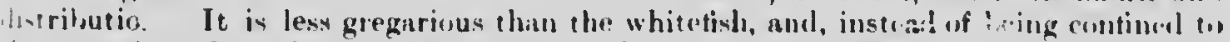

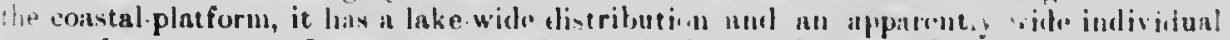
runge of movement. It apparently seeks its tool at all deptlo amil tiuls it in comsider hin sariety as ! is, therefore, mut unch affected by the pollution of the buttom. . 1 !

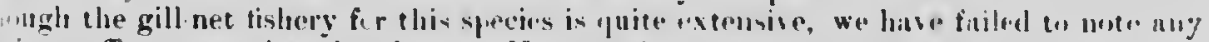

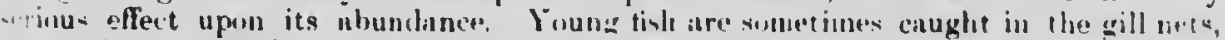
"it as they usually become entungled hy the teeth no rommly vaggests it weit."

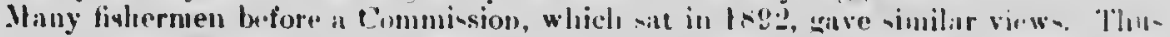

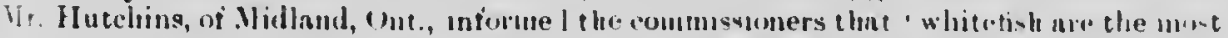

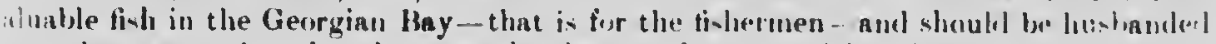

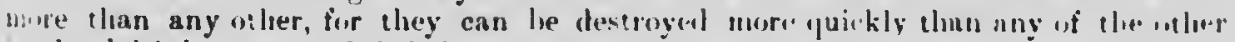

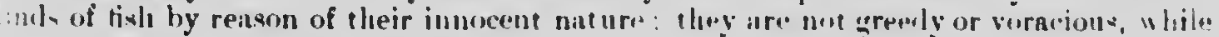
inon-trout feed largely upu'us them."

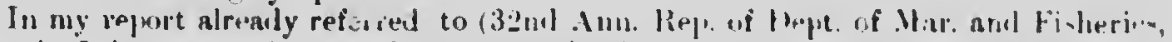

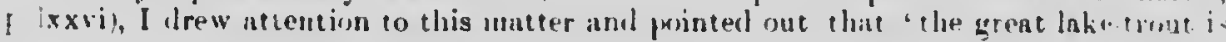




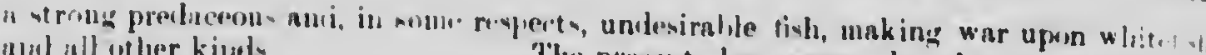

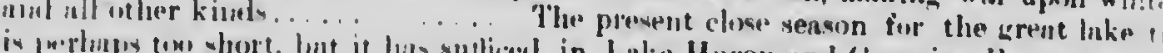

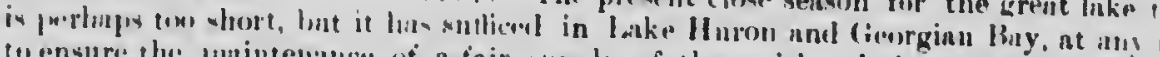

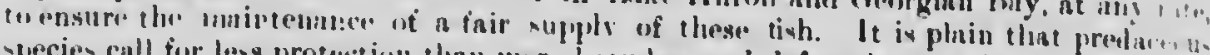

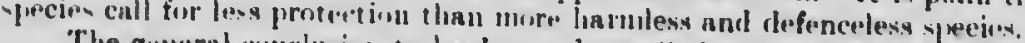

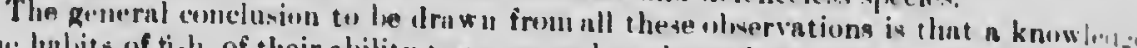

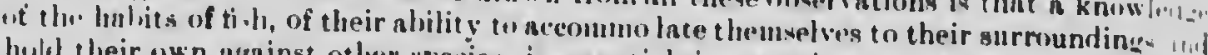

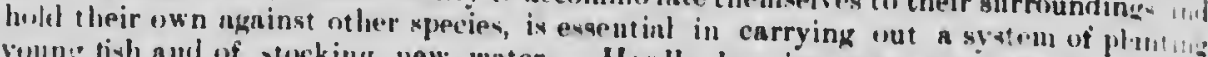

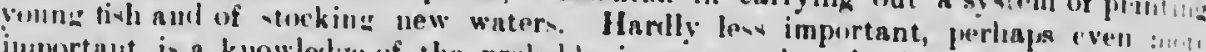

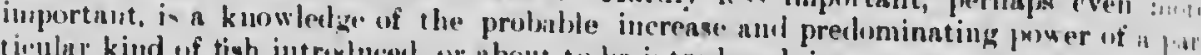

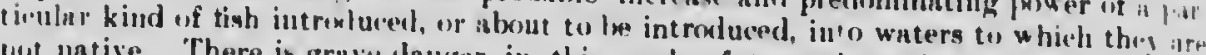

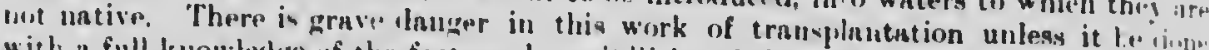

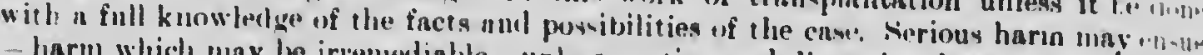

harm which may le irremediable - unless caution and diveretion, basel upon acenrate

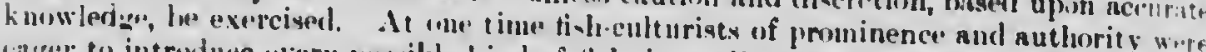

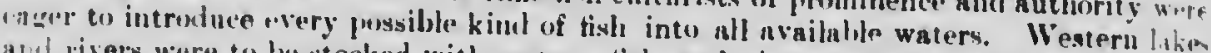
and livers wire to be stocked with enstern tish, and rice wern, while a great variots

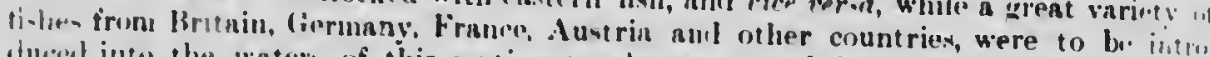

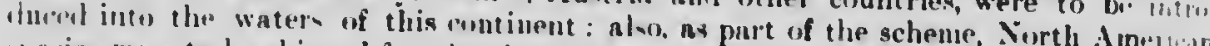

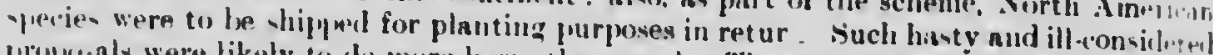

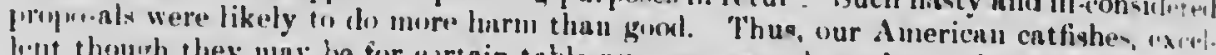

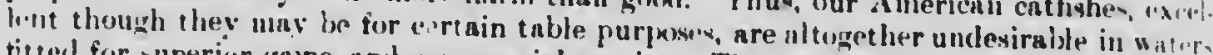

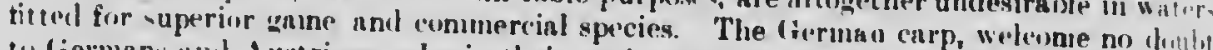

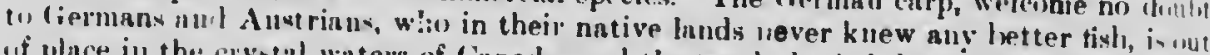

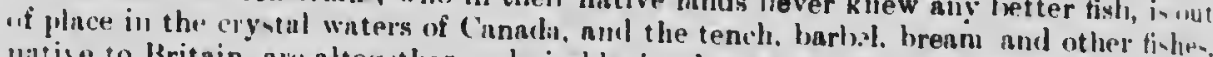

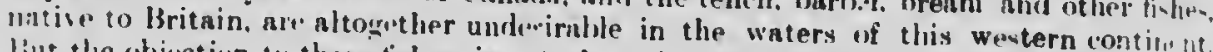
lint the objection to these fi.shes is mot that they would devour or drive ont our mente levirable natiwe tishes, but that they nro not worth the rom they would occupy 11 . nur watcr, nul the fond which they would devour is required to sustain and nonli $l_{1}$ th

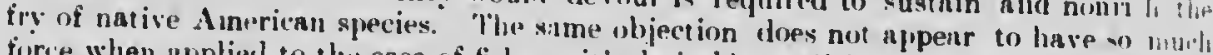
turce when applied to thre case of fishes with desirnble qualitire. Fet the poliey adherel (1) by the Dominion (iovernment "ren in regarel to such fish has leen $n$ wise one. $X_{1}$ encourasement has been given to prop.osals to hateh and strek Canalian waters with

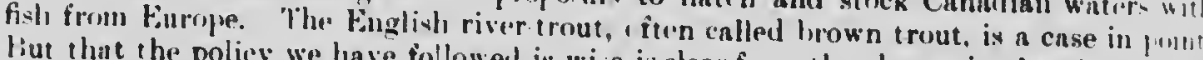
fiut that the policy we have followed is wive is clear fron the change in the views of the principal l'nited states officers ch rned with the work of Federal Fish Culture. Thu.

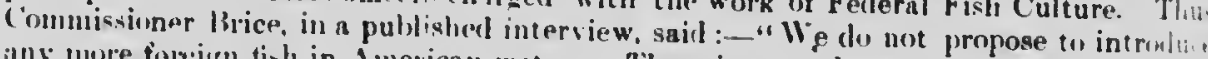

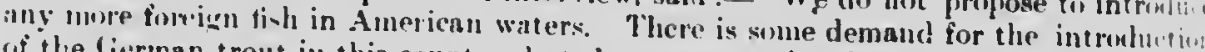
rif the cirman trout in this country, but the persons who desire such all importatin "pparently do mot realize what an effect the appearance of this tish would hav' up" wur native varie es. The dierman trout is stronger, harger, more vigorous nnd viciniund grows faster than any of unr variety, and if it were introduced into this countrs in "wold 'puirkly drive out the hrook-t rout in the Fast and the rainbow-trout in Califoriij ' Oo,' continued Commissioner Brice, 'the care and preservation and increase of th ti-hes indigrnous t." American - treans. or which have been found to adapt themin.... to wur witers without driving out or destroving the native variaties, should he the aim and ohject of the Fish Cummission.

Hance a comparatively small number of trout will thrive, as just renarked.

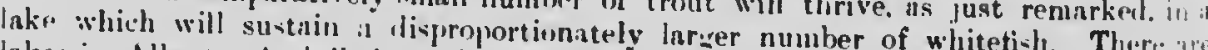
lakes in Alberta, Assiniboia and saskatchewan which at present viell an abundant -upply of telicio:ss whitefish to the spttlers, and Indians and Inif-breerls: hu: thut

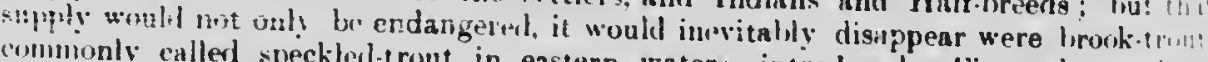

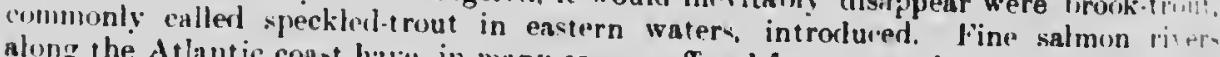
along the Atlantic cont hisl', in many cases, suffered from trout, bo $h$ the fresh wat and the sea-run variety. Incerd in the provinces of Quebec, New Kruncwick a Prino Filward Island. some risers have heen to seriously orerrun that the dimirutis "f " milmo: in them may he largely tracid to the excessive number of trout. It inctual!y urged a fow years ago that the use of dynamite (prohilyted by statute) slu, 
SE JONAL PAPER NO, 22b

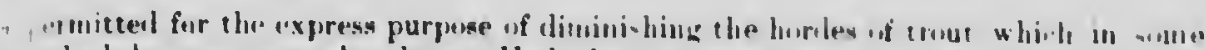

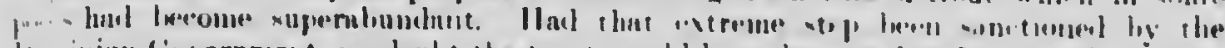

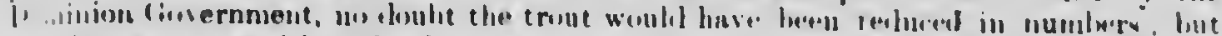

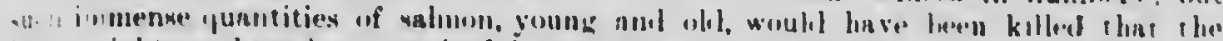

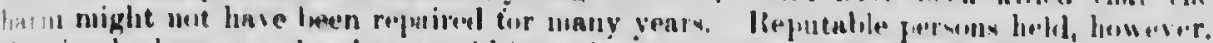

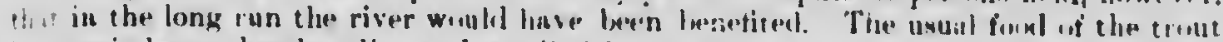

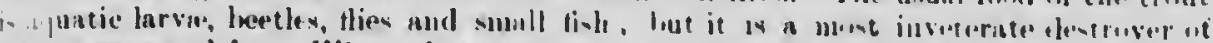

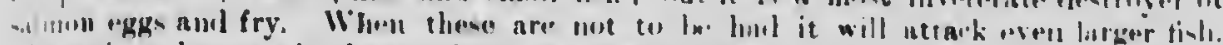

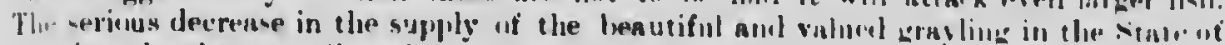

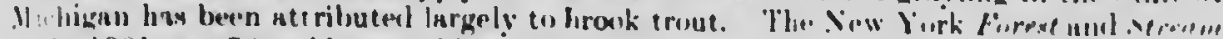
(.) ily 1901, p. :78) said "1pon this matter:-

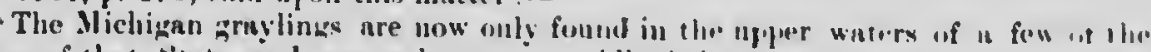

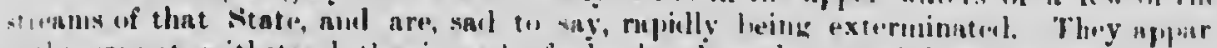

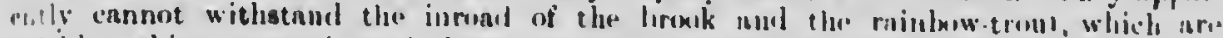

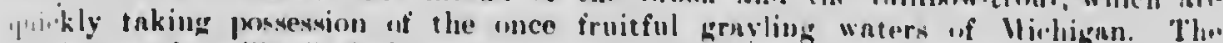

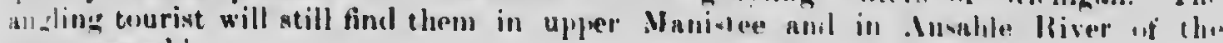
"inte namel.

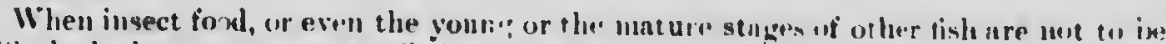

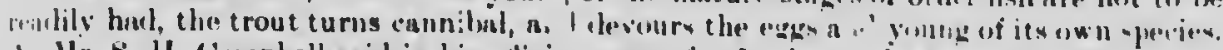

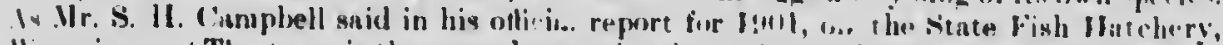
11 yming :- The trout is the most dentructive finn tu its kinrl, in the matter of clestroy.

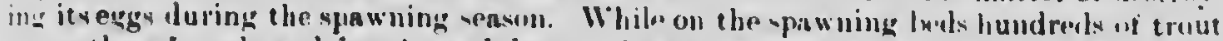

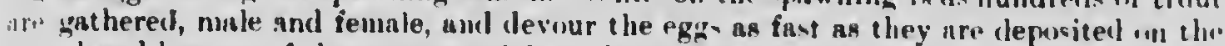
arisel and bottom of the strenu or lake. It is only the eggs that uro coverel or inll

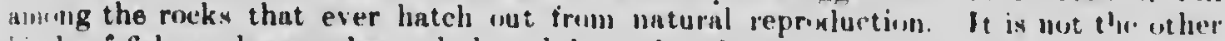

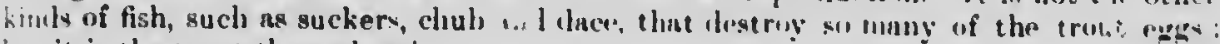
list it is the trout themselves.

Specie: which for market of for sport are of highest value to the communty have

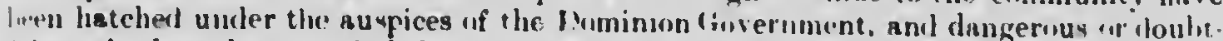
tul -pecies have been excluded. Am.ngst the species which hase rarely, or mot ut all.

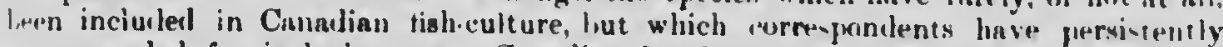

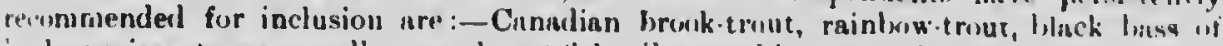
in, sh species, sturgeon, veilow jurch, cut-tish, pike, miskinmmin nnd wther kinds.

Let us take the lirook-trout tirst, for in the upinion of most prople it is utisls which can the regarded as out of place in .. lake, livere, or strom. It is a mintako to introduce brook-trout into lakes in which whitefich noe nhundinnt, unlews such lnkis ha uf great extrut, and contuin sonviderulile depths.

In our North-west Torritories, where tish have n very specinl alue, a villue hally. tw he paralleled in other provinces less remote from the seacciast ur grent lakes, 1 s.llail

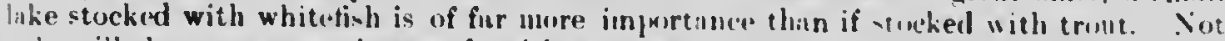
"hly will the sane aren of water furnish a grenter amou l. of tioh funl (if whitoliah a..

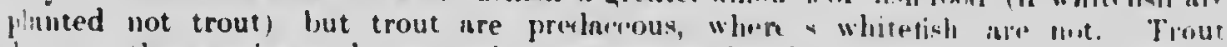

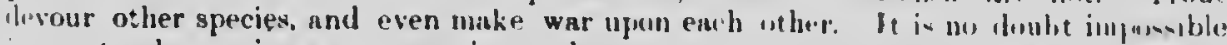
in mast sulmon risers to exterminate the iront, ur prevent their inmuls: hut avety

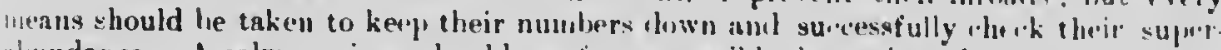

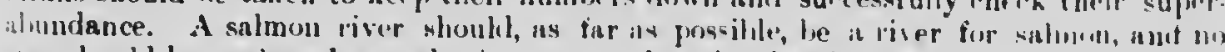

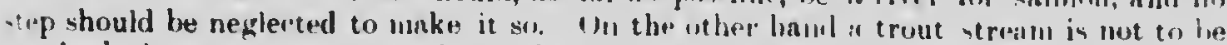

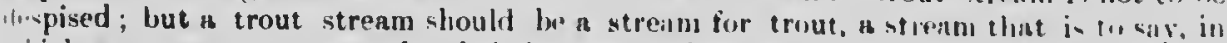
which every encouragement for their increase and welfne, and every protertioll anills-t

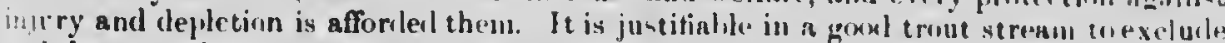

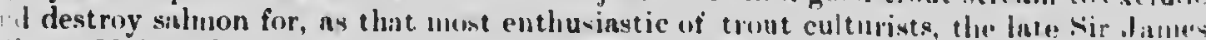

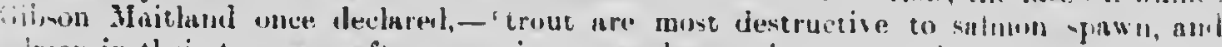
- inou in their turn arc, nfter spawning, inost lesiructive to truut.

Closely connected with the brook trout persus selmun question, and the im.un

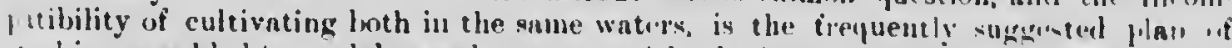

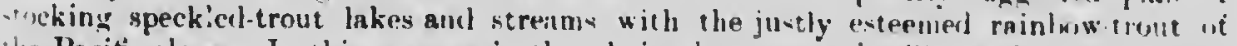

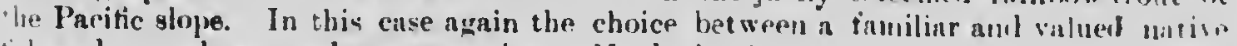
t.h and a much vauntel stringer arices. No doubt the minhw-trout is a harty, han'l. 


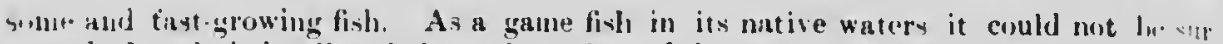

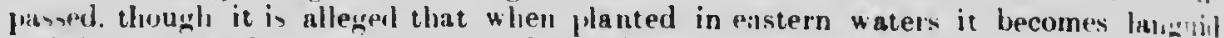
:ul inactive, and grows large and fut and lasy in its new surroundings. My ..1, "pinion alwnys has buen llat wur enstern brook tiont is the lest fish for eastern witurs,

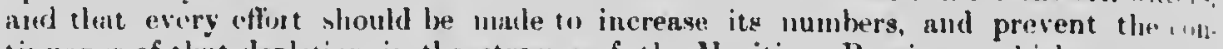
timunnee of that depletion in the streans of the Dharitime Provinces which must - itat result in extorminntion. There are hun treis of streans, not naturally adapted in. shmon whith would well repay restocking, and more active protection. Such strins ui) doulte might le stocked with rainbow-trout. The suggestion has, indeed, lan-u repeatenly mate, nnd in one of our Dominion hatcheries rainbow trout purchased at the

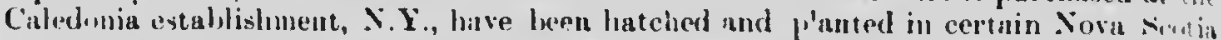
waturs, liut I mustrongly of opinion that the native bronk-tront are to be pretomil, and in this "pin on I find inyself confirmed by the views of a most able and acconplivi...1

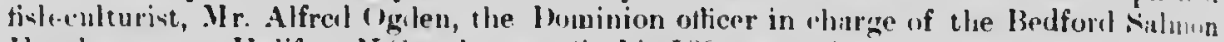
Hatthery, near Halifax, .X.s., who says (in his 1894 reprort):-

- Although the ranbow-trout is a good gane tish, an actise bitel and mak. a stroug fight, giving great sport to the angler, I think that it would be a great misi, k" t.. introcluce it into waters where our native trout ah unds. W'ice ford is plenthul. and watcr- mokerately cool, the rainbows will grow fist and attain a weignt of fr in

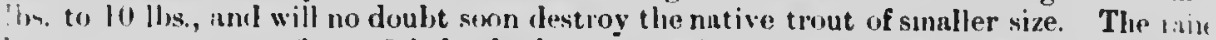
low trout are not as tine a fish for food as our native species, and the flesh will not bin. long after being tisken out of the water.'

I am of opinion that the Pacific trout will be fount to destroy both the ega- aut young of the eistern trout : but that remains lo be prosed. Their rapil growth and

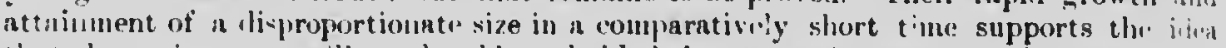
that the native trout will int lu able to hold their own against the introduced strali... Huw i:ipurtant, then, it is to hase more information and to use extreme caution beting

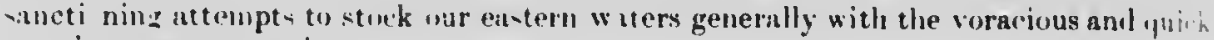
urowing westrern species.

A few worly upon the stocking of new waters with the justly estermed bla $k$ lass, are highly important when dealing with this subject of the planting of prediacous: ti-h. The black hass of both species are typically predaceous tish. The rejutation which

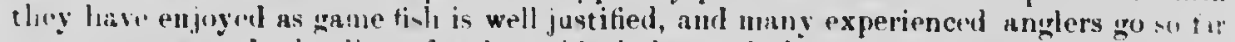
an to compare the lamling of a large l, lack hass, of the vmath mouthed species. In the landing of a sialmon. They are most musculan and powerful, and not casily played

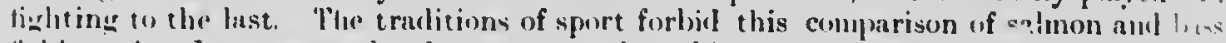
fivhing: l,ut I wat assured, a few years ago, lw a high government oflicial from Huglat d.

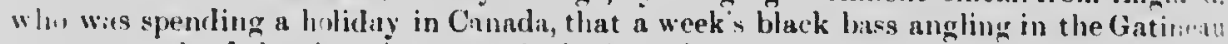

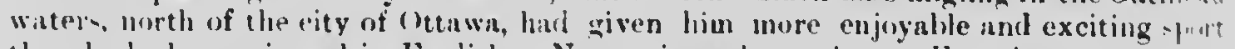
that he lisl experiencel in Fuglish or Norwegian salmon rivers. From its vory vintits the black biss is a bold and tieren biter. The nngler neel rarely be disapp intel it if

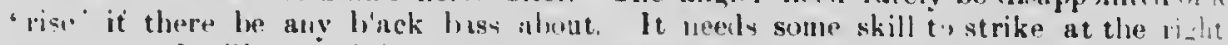

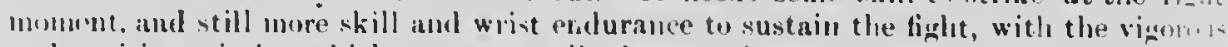
ant untiring betim, which poisesess al the conning and activity, and almost

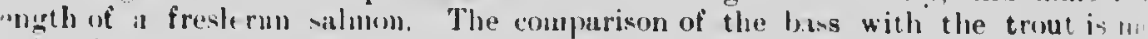

missible perhape than that jut refered fo. One of the best known anglop.

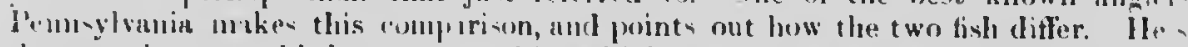
that to play a speckled-truut gave him a higher and beenco senso of delight thin

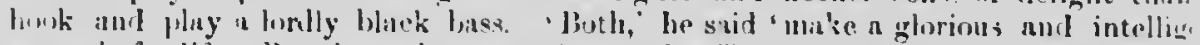
-truegle for life. But there the comparison ends. The trout tights like a trained hos. ther welier like a salage. One arouses all my admiration and the other iny blond. II

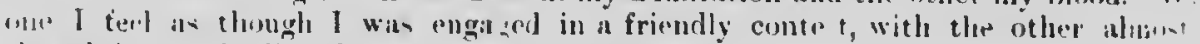
thrugh it wus thr. lite of rither my nelt or the hiass."

There is a liack of refument ahout bass fishing, which wath it wit at ane , from the trathitional itately confliet with that monareh o: the river, the salmon.

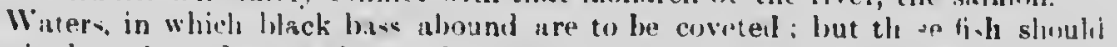

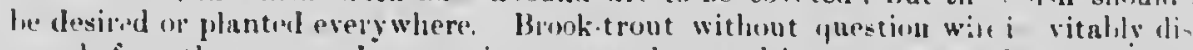
prar befire the new and pugnacious marauders, nud in unst cases the trout aro preterable tish. Is a matter of tict a lake will sustn: for fewer bass than brukbetro 


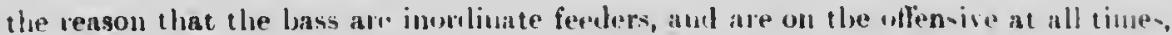

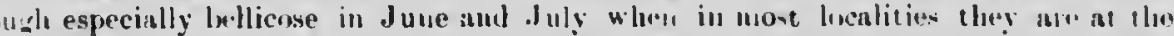

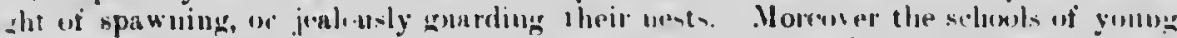

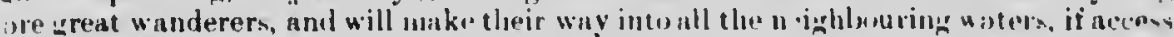

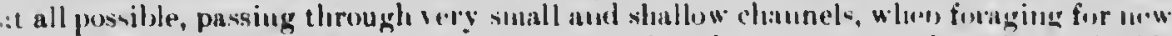
aling urrunds. Winters should be well suppliol with numbrous and anall eyprimide meler to sativif the voracious appetites of the lams as tory are eypecially liable ta risiter and disease if allowed to get into pour comblition. nuil not supplied witl ample

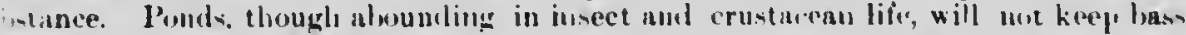

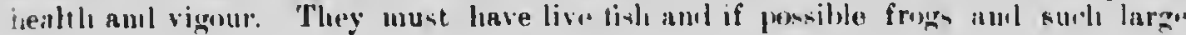
antu" for finol.

At one of the Luited sitates luntcheries (Nemshosta, Miss.) five or sis years anu, it 1. tound in rearing bass and brook trout in ponds that there was a very serious lous,

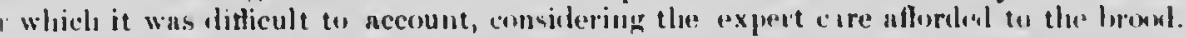

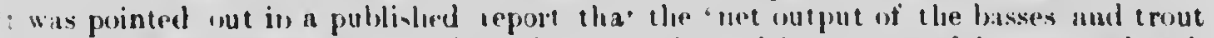

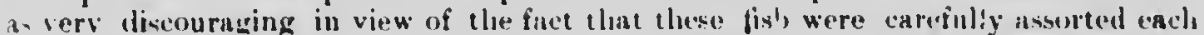

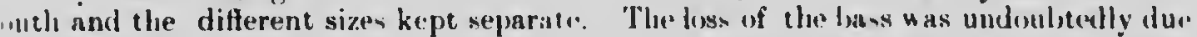

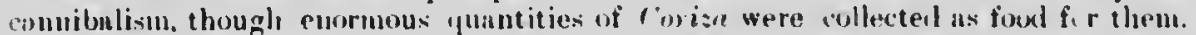
Thi, food is very acceptable to the inek lass, but the liack loss lawe been ubiervel to

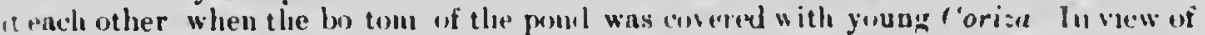

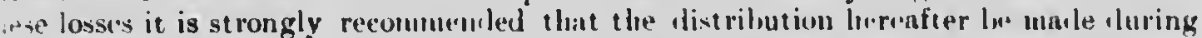

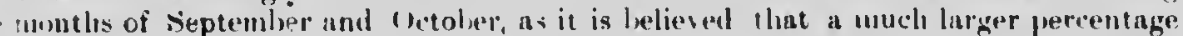

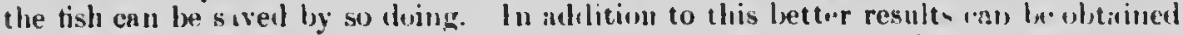

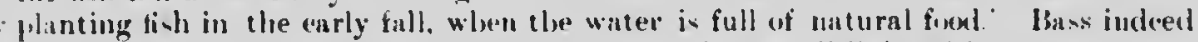

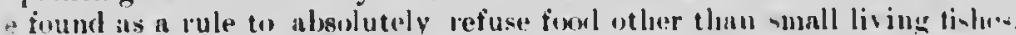

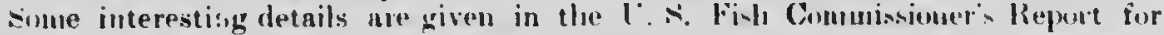
$\because$ ( 11 ushington, $1 \leq 99$, ) on experiences in the artificial froding of rarious species of

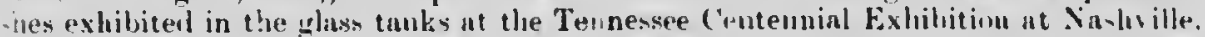

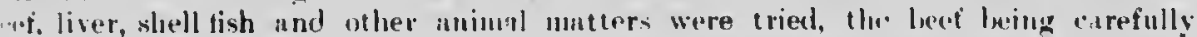
"-sted of the fat und sinews, and eut into small frogments auited to tho various fishes.

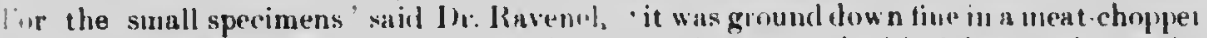

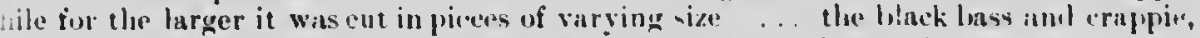

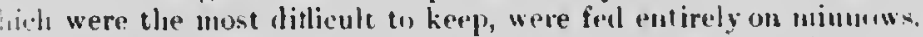

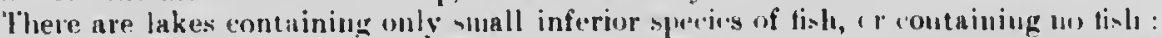

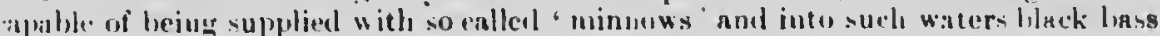

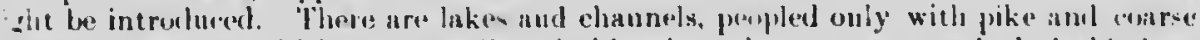

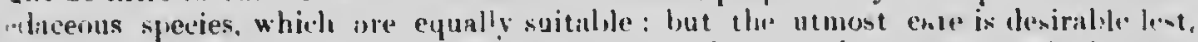

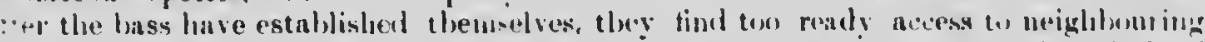

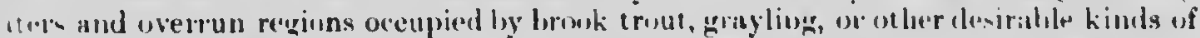

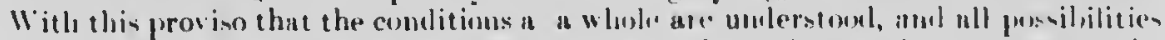

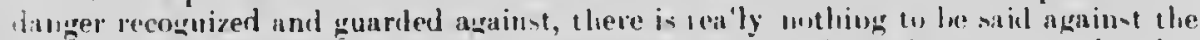

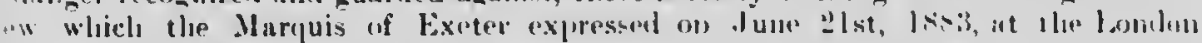

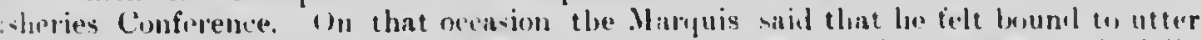

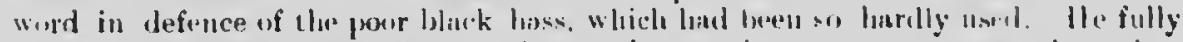

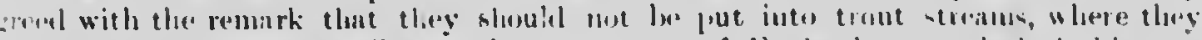

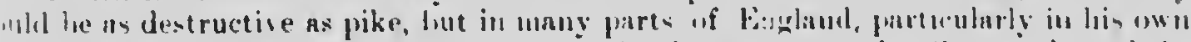

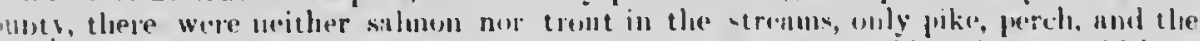

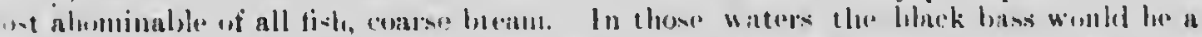

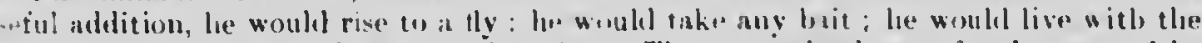

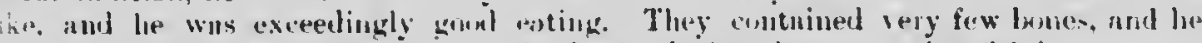

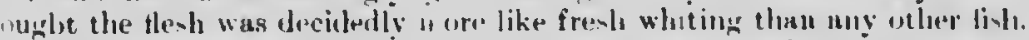

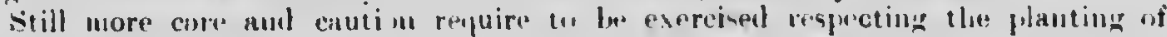

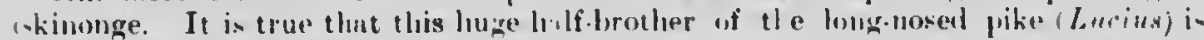

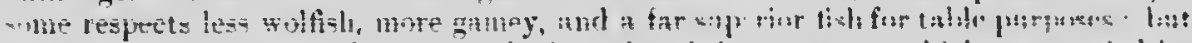

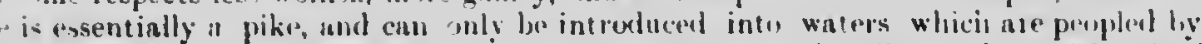

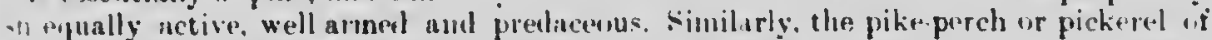

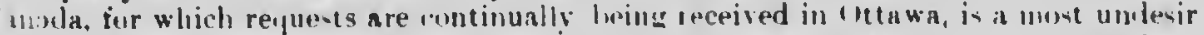

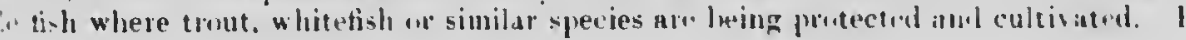


fully agree with the "pinions of a cespomlent in forest and Strean, N. Y. (April : 1 $1900)$ who atfirms that 'every angler knows the nature of the foocl of the ind muscalonge anct also knows that it is a fish of the cold Northern waters. It is certair. one of the most vorncious fishes known, and in haljits is to le closely compared with

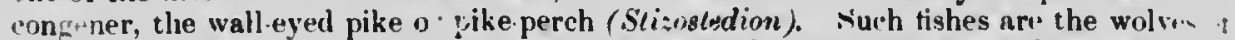
the waters, null their introduction should be attempted with grent care and knowledg i i the waters into which they are to be placed. Wherc they become abundant ti.-.y effectually kill off nearly all other kincls of tishes in the waters they inhabit, especi: $y$ if it be an isolated ponil or lake where other fishes do not freely migrate into it. If -11 fond ur lake contains only the coarser or less valuable forms of fislies, it may be well stmek it with muscalonge and walleyed pike, but if tine tish or other desirable gati. tish are abundant, it is certainly advisable to prevent these wolves beneath the wat... from exterminating inore valuable forms of hife. Here ngain is tlecided need of biolegi al investigutions to determine what waters should be and what should not be stocked " i ? such tish.'

Of pike, sucker, perch, catfish and similar conrse predaceous fish little need t,w saicl. There inay be ocensionally inuddy ponds or isolaterl lakes where these tish cou'.। $b^{2}$ safely planted without risk of their overrunning the whole of the waters of thin adjacent dlistrict: but it may be laid down as a general rule that these tish do not $1 \mathrm{ki}-\mathrm{l}$ the aid of artificial fish-culture and they should be kept as far as possible within $t_{3}$. present range. 'To introduce them into virgin waters where they will soon inevitai hold supreme sway, outnumbering and overcoming in an increlibly short space of ti: the indigenous kinds of tish, is criminal. Well might an eminent $L$. S. fish.culturi declare, $\mathrm{n}$ yeilr or two ago:-

- There will be no walleyed pike distributed. We have received many reques:for tish of this character under different names from various parts of the country, $b$ : they are all wall-eyed pike, pure and simple, a nost pernicious and destructive fish, aml. ns I said, none will be distributed. The perch is another destructive fish. There a: very few memlsers of the perch family that do not come under this condennatury head. Like the carp, they follow the schools of fish and vean oy their spawn. The damage clone by unwise planting of tish it may never be possible to undo. At rectis: private letter riceived by me, from a woll-known gontleman in the province of Quclen. inclicates bow seriously sucl a fish as the yellow perch uay atfect tine angling likes:"I own "he says" a lake in the County of Portneuf in which, some years ago, nothin: lut trout could be found : to day, however, the only fish found there are perch.: In soune Caurdiun lakis the yellow perch, formerly unknown or not occurring nuustro siy. has increased so rastly as to indanger all other tisling. The Ponnsylvania fivisury authorities wrere the first to point out, some years ago, that the yolluw perch, in ewn. la gi a body of water as lake Erir, were beconing a menace. Curiously enought they increaserl in the greater waters, they were observed to becone senrce in the smalien? laki's and streams-to puote from their report. - While yellow perch arr beconing? serree or hwe disappenrerl in some of the streanis and ponds through the thouglitlessn.... of anglirs and loys, nud the ravages of pot hunters nnd criminals, the fish sein to actually on the increase in Lake. Erie and in the other great claain of inland stis - if which it is one. To such a surprising axtent is this true, that a large number of th.". lake tishermen berame firmly convincer that the Fish Commissioners of this and of states, as well as of the United States goverument, had confounclel the identity of yellow p'reh and the whitefish, and had taken to hatching und depositing the fry if the former in the waters instend of the latter.

The' spawn of the perch is one of the best adajted tor accidental transportation in. one lak' or river to an other, and, while in many case's th" regrettable step ha hiw. tak.'n of netually depositing spawn or fry in new locations, there arc no doubt mult tur

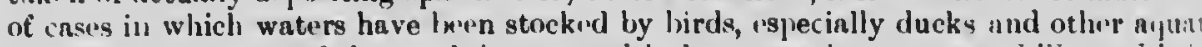

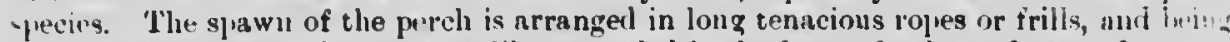

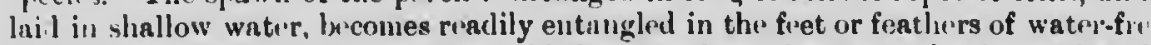
ing nuimils. When yellow perch establish themselves, they soon dominnte the whol the locality, and are most ditlienlt if not impossible to extrrminate. I newsy! publisherl at sturgeon Bay, Wiaconsin, recently staterl that 'twenty tons was abront? 


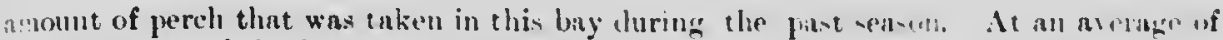

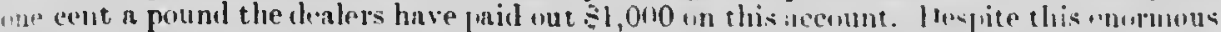

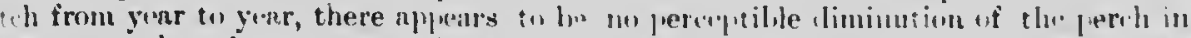

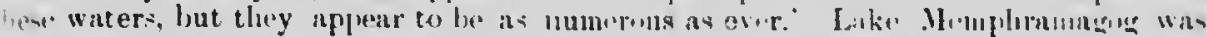
wer-run with perch a few years after ther wore planterl la perams in "prmont thmin

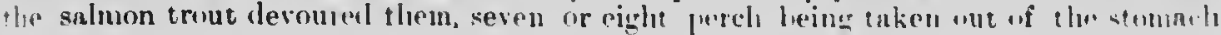
it it lisge trout.

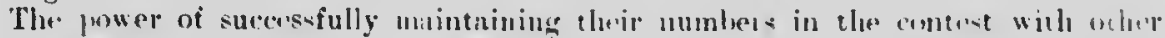

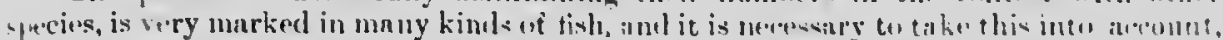

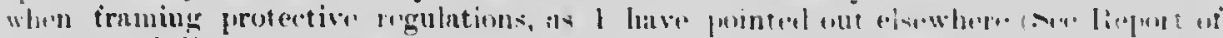

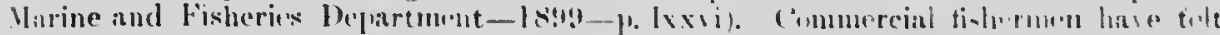

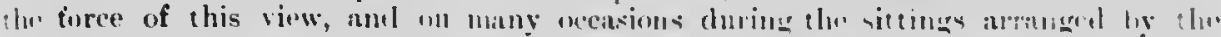

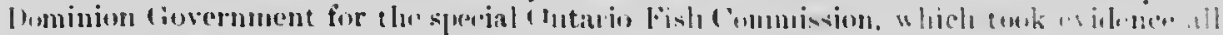

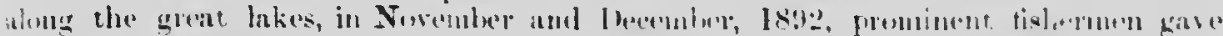

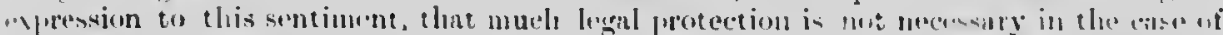

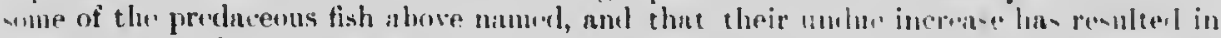

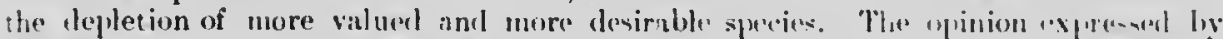

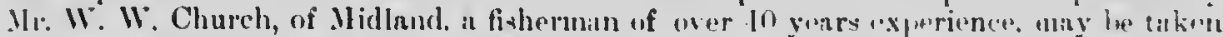

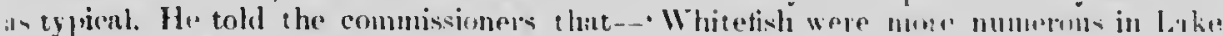

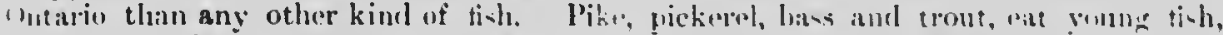

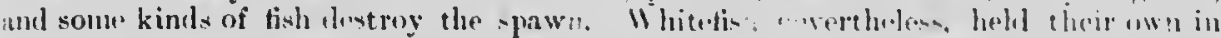

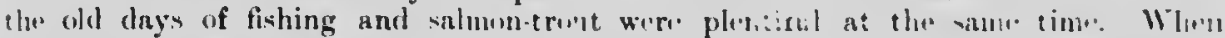

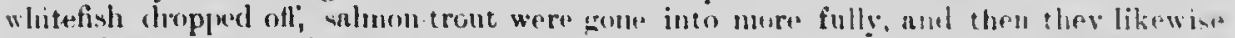

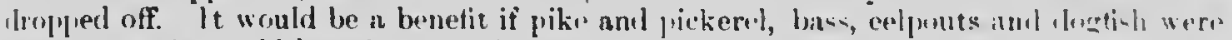
itken out-it would benefit the whitetish.

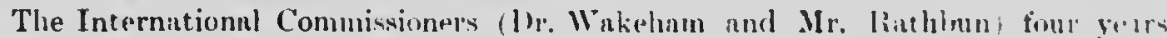

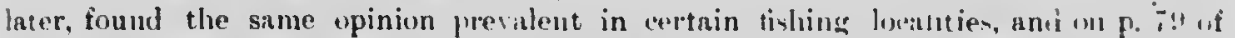

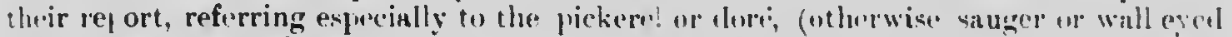
filie), they remarkm that "the policy of afforeling any measure of protectiun io the w:all.

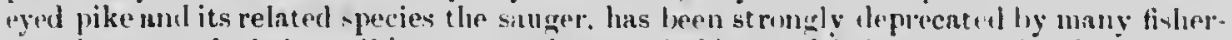

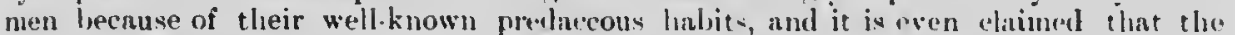

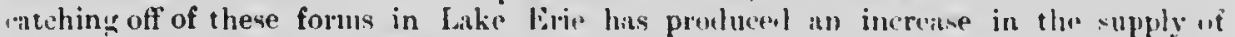
herring.' W'hile the Commissiones did not feel uhle to accept the conclusion realiev by the fisherinen, they placed on record the fact that the pickeril (b) as and yellow) are vary Iestructive to other fish. From their on nesumination of speciumetley state that ihe: species seems almast entirely piscivorous of maug "xampies examiunl, nearly all

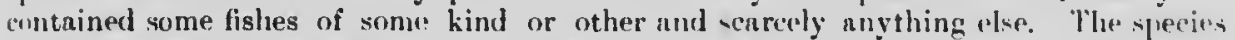

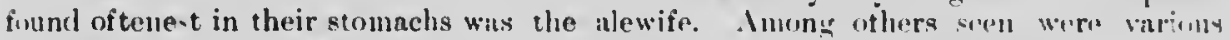
minnow, young yellow perch ind yound suckers. Su young whitetish, tmut w litie herring were seen in their stomachis."

The exclusion from the scheme of Canmlinn fish-eulture, as arriel on under

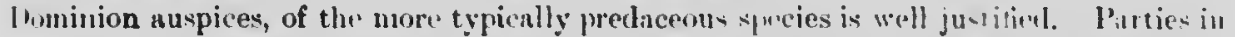
various provinces haw becume impatient of this striet limitution, and in the puss and

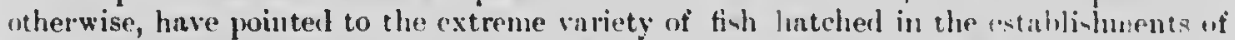
the United states and other countries. Hut it is beter to be wise in time liven in woll-protected and carefully supervised witers, like the qunting lakes nul rivers in

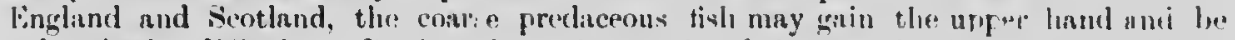
melucerl with ditfieulty. During the early montls of the year 1 ! 100 t.." whters of the Farn, in Perthshire, scothnd, werenverrü by pike, the local journals ta I ri: annum:e-

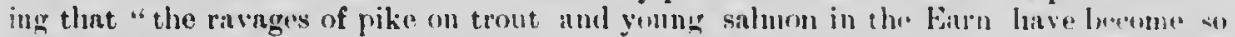
great, that the river watchers have had instructions to net ar many of the wrobus luarauders as possible.'

In the truo interests of fisl-culture, destructive mensur!s are as necesinry as thute of propagation and rearing. 'The 'wolves' must br destroyed, that the ialuable lati.hs may have a fair chance. Ill-weeds, the old proverb declares, aruw apan, and as a lul." the coarse inferior fish are nhle to look well after thensolves, tou well, the tivh culturicts wfen thinks, when he realizes the ditliculty of dimini-ling or of wholly clearing thum $226-2$ 
out. Exceptimally, some of these fith may be tolerated. As the Juwa Fish Comm.-

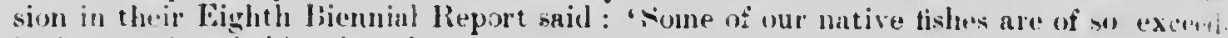
infly voracious habits that they are, or hase heon, comdennel as untit to plant in any waters, lut we have many shallow mud lakes that are totally untited fur the luter grarles, and the soracious pickerel and yellow perch are perfectly at home in them. "l h.y

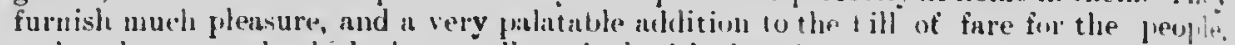
and such waters shouli le kept well stucked with them.

Artiticial tish propatent iun it intelligently carriel on takes account not $0 \%$, of tim

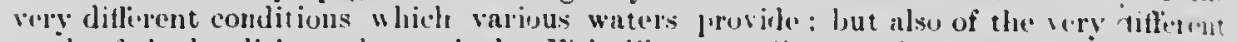
nearl of the localities to les streked. Fish, like the yellon perch, which are iletested in sone waters, alle resircled in others an desinhlie fish tor angling purpunes. The fullowing

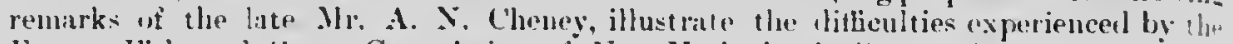
Forist. Fish and fime Conmision of Sinw Yonk, in dealing with appliention tor supplins of brook truut.try. He said :-

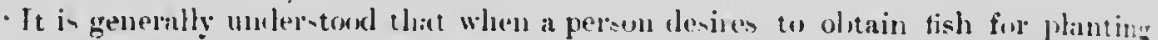
from the loorest, Fish and (isune Commission of Sew York, praticularly if the fish wantent

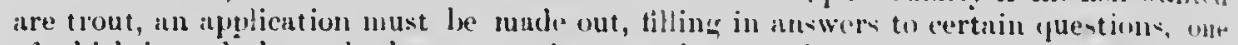
of "hich is to dechar whethel ol mot the water is natural trout water, and another in t" state the kinds of $t$ other than trout, that ane in the water in which it is lesired that the trout be planterl

- Hore and more, apparenty, the answer th the lant mentioned quastion is "pickerel" the pike commonly alled picieirl. browk-irout and pickerel do not, as a luk. thrive in the sante water, aside from the fact that pickelel will pres upon trout, hu: occialonally pickerel will make their way inte and estalibh themselves in the mmis waters natural to trout, and generally the comminsion dechines to furnish tout to lee planted in waters that pickerel have inaded and hecome a fixture. One man wrote.

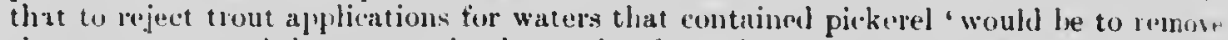
the greatel part of the streans in that region from the list of trut strenns : Anuther. applicant who land declared that pickerel were found in the strean for which he wivled the trout wentione? in his aplication, made " personal call upen the comuission aftel his alphlication had heen rejected, and argued that he should hase the trout lie ankend for hecause he had been frunk enough to admit that tho stream contained once in a while a small pickerel, for le thought no one olse would have made the adnission. He was soluewhat surjerined when there was slown to hinl a leport made by one of thestate

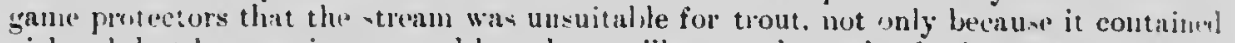
pickerel, but becalue it wa used by a largi villige as the outlet for its stwage. Invere

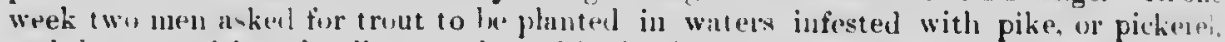
lock hass, sunfinh and yellow perch, and both arluitted when questioned that the water was mot suitahl. for trout, but they thought if toout were planted this net would stup! winter tishing though the ice unders. tion tis of the wanc law, and they were inclinterl

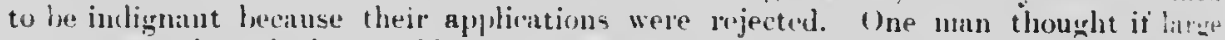
trout were planted they could protect themeshes from the pickerel. The Conumisin tries to inforn itself nhout any wacer in which there is the least loubt as to its titnen for members of the salnem family, anc su when the appli-ant's answers to the quelip no tho application are mot enclusive, she state sine plotector of the district in which the water is situated is anted to reprent on it. There are plenty of streans and ponds that

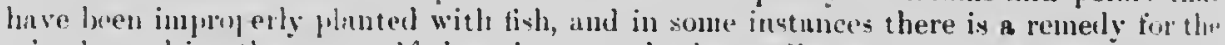
mintak' anl in others not. If there is a rentoly the applieant generally wishes the atate

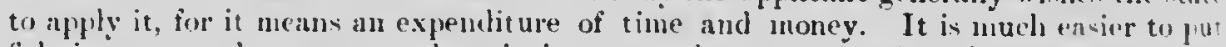
fislt into it pond wh atram than it is to get them out after it is discovered that the putting at them in is a blunder.

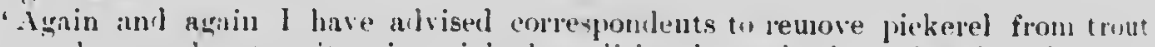
Walters ant try and restore it to its original conlition insteal of put ing in other tivel. gencrally black bas, that cannot be romosed.

A word lezalding the sturgen must conclude this hasty sketch of n larg" alurl complicated suljoet. "There is a universal opinion amongst fishormen that the stursm

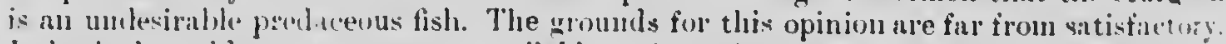
Indeel, the covidence at present available points the other way, as the stomach if 


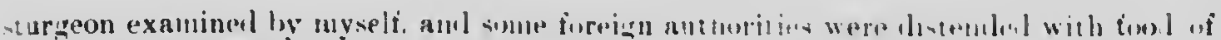

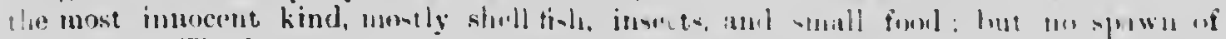

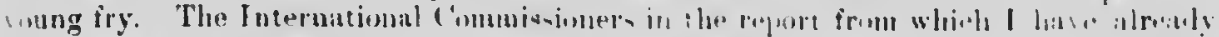

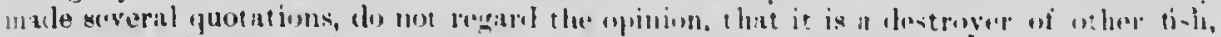

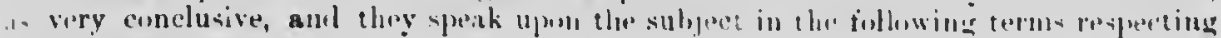
l.ake" Frie sturageon :-

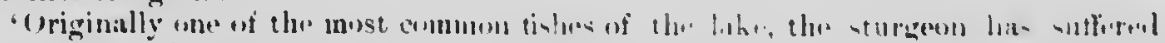

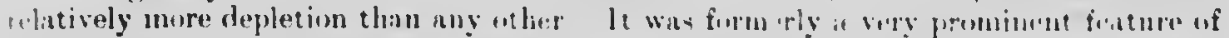

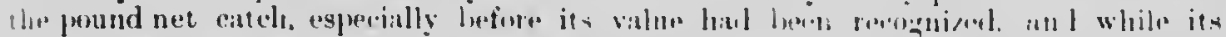

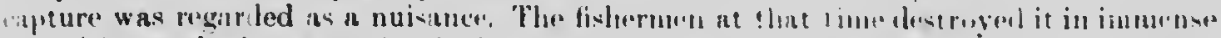

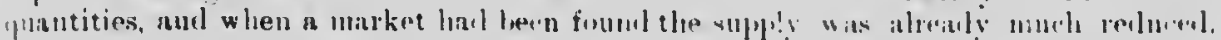

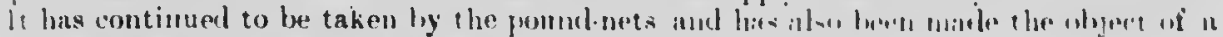

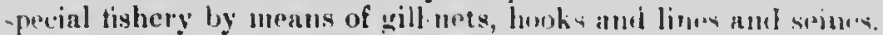

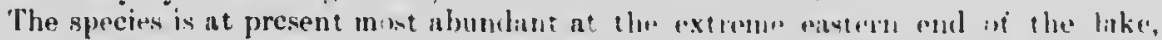

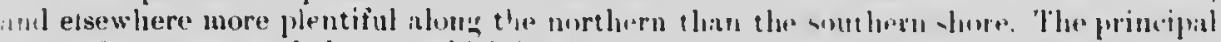

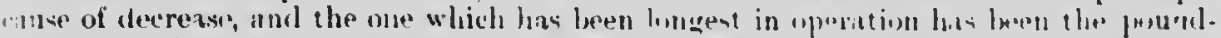

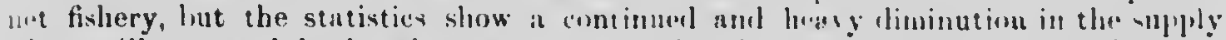

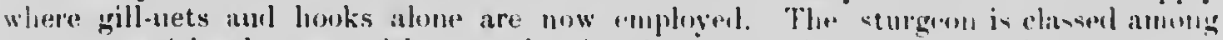
prediceous tishes loy many tishermen, lont in what ilonges it morits this distinction we"

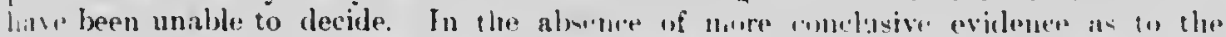

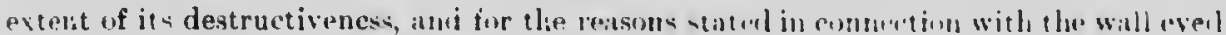

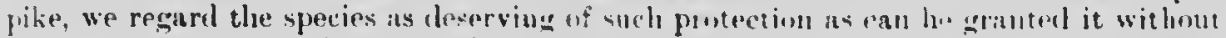

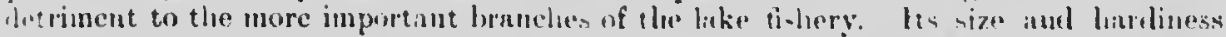

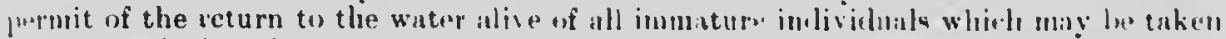

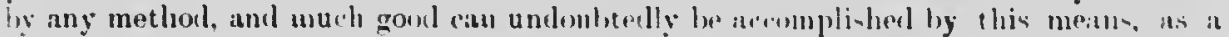

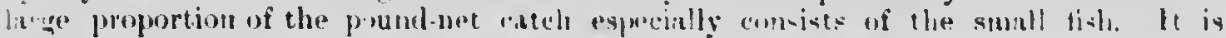

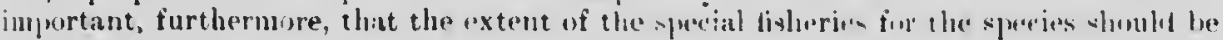
minterially recluecd.'

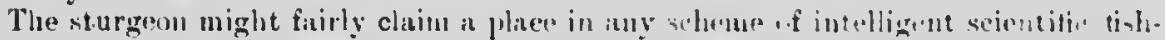

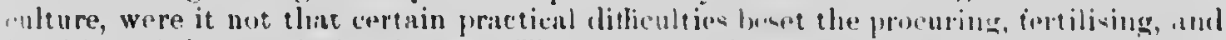

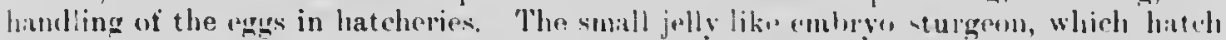

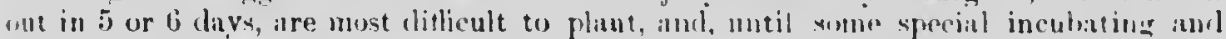

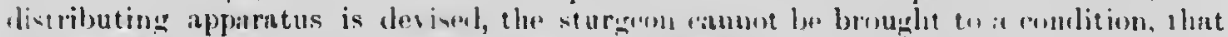

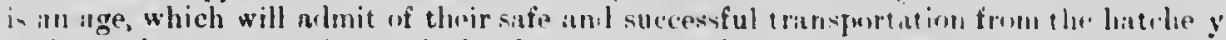

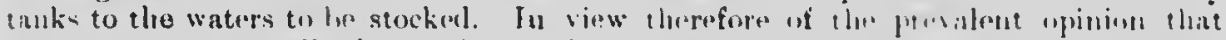

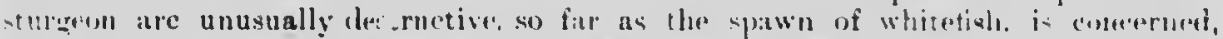

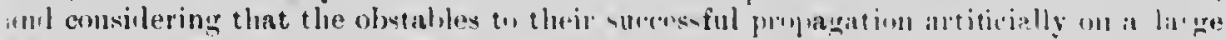

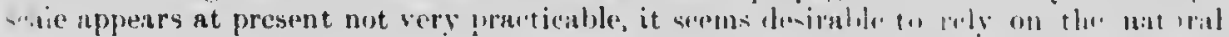

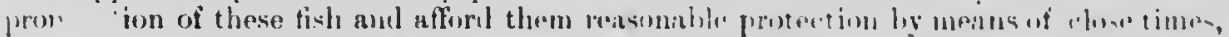

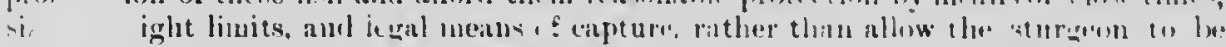

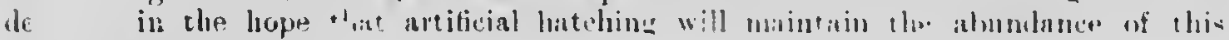
inc, rigly viluable $\mathrm{n}$ :

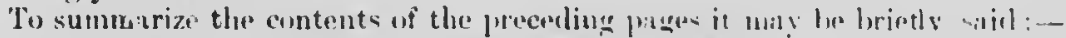

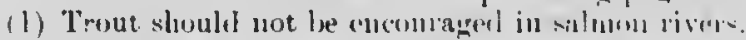

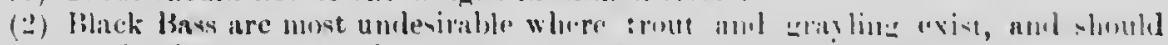

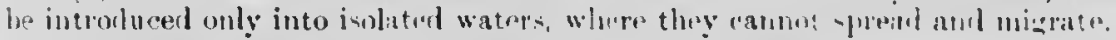

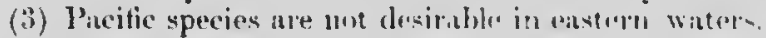

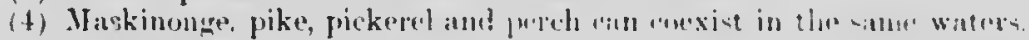

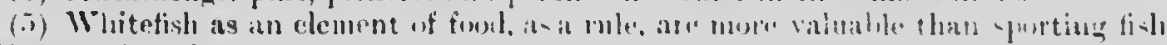
ii Nestern Cinada.

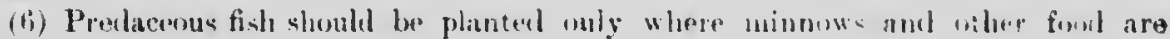
it)indant.

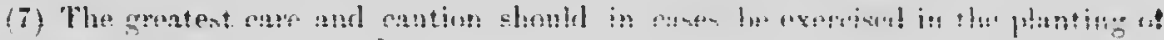
preilacenus species. 


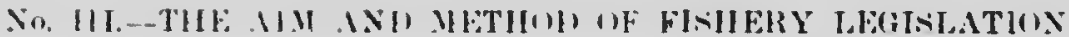

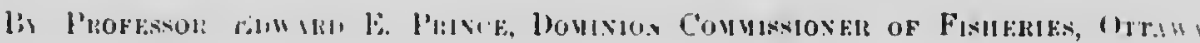

A special repurt which I published in the lopartmental (Fisheries) blur bouk in

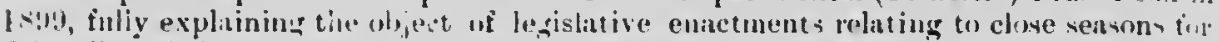

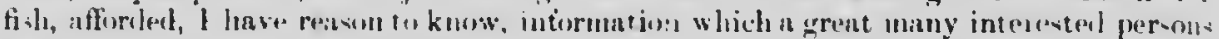
had suught for in vinin. The subject is one sery monnonly misunderstood, if, indered, it

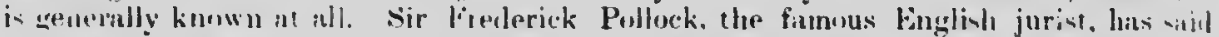
of lisherg laws, as in whold, that their very existence is hardly known except to $t_{1}$ e parties interested in their subject matter, yot, he alded they ure of crinsiderable exlout and intricncy, and uny ruise importint yuestions of general leginlative policy. "lhu, it is "rident that in the case ot the tivhery laws, the question of interference with prosto

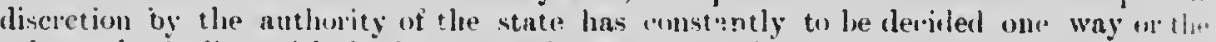
rither. In deining with fiesh-witter fisheries the tendency of modern law makinut his bern to impos" new rentricriuns: in dealing with seil fisheries to remove old ones."

In the repurt, above reterred to, I pointed out the vory diverse reisons, whinh loll to the framing of the defferent existing close seasons for fish of economic importance in the Dominion, and numerous letters, aiddrensed to the depar'ment, or to ine persomally, show that my attempt had furnished precisely the kind of aformation that was derinu

The ains and oljects of all etlective fishery legislation, apart from what is callal International law, may be summarized under three of four heats: but the methork in: which such itms and objects are nchieved are complicated and various. The methul of tishery legisfittion las heen moulded into such diverse forms that the body of t'nart. ments in Canada, as in other countries, is cumbersome and complicated in the extronies. The Canadian code of fishery laws and rogulations is the result of gradual growth ani accetion though a period of many vears, and its various provisions exhibit much (1) e. lapping and inconsistency, if not absolute elf contruliction in some cases.

In various parts of the looninion there is a common impression, though a growity mistaken one, that tishery regulations are merely a means of securing res enuc to the govern. ment, and are escentially a uethul of ensuring a form of indirect taxation. If uch of the irritation and resentment at fishery regulation aroused amongst the fishing populit. tion mily be triced to this erroneons iden. They say "why should cur vocation, ou" means of liveliloonl be tixed, ind others go tree?" Certainly tishery regulations afliect the tislerman's vocation, and the imposition of licente fees, the infliction of fines and pentitire, incl of her subsiliary iccompaninents to legal processes, bring to the pulblic treasury, pecuniary contributions which are atded of course, to the public revenue. Fishermen ire led from this ci eunvtance to regarl fishery law $\rightarrow$ as a somewhit covert method of compin. ling then to pay additional trilute to the state: and government commissions, conducting infuiries intu tisliery matters. encounter no obstacle greater than the unwillingnes if fishermen to help, is they think, in furmulnting new and oppressive enactments, ani the exaction of further license fees and taxes. Fishermen slırink from freely and fully telling the facts, through tral that further and perhajs more stringent legal burdens may he laid upon them. The complaint, en exanination, is found to be a very inistaken une, and one very far from just, so far as the Dominion government in concerned. It is notewortly that the governin'nt of (anada, during the long period of over thirty yeir-, following conteleration, dnring which periol it exercised the predominant power if issuing leases and licenses, of collecting fres, and of enforcing preservative and protectise regulations, naver regarded the tielning industries as fit sulject for tisxirtion. All res cusue resulting was ancillary and incidental. The federal government has cousistently disowned the desire to 'make money' out of the tisheries, during the years when very high authorities held that the Dominion nlone hal the right of property and jurisdiction in regurd to tisheries. It has alherel to the same view since the announcement of the

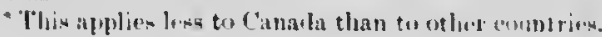




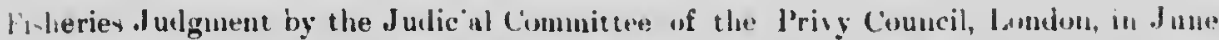

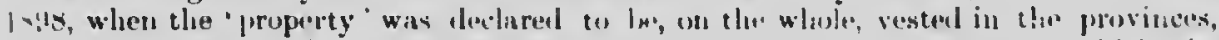

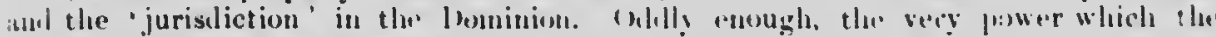

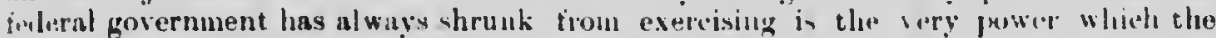

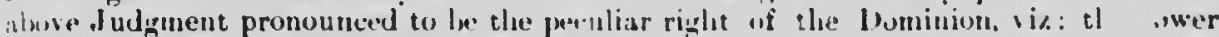

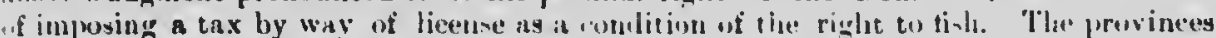

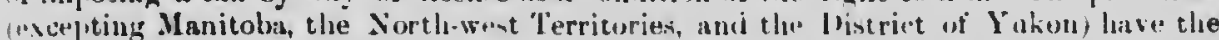

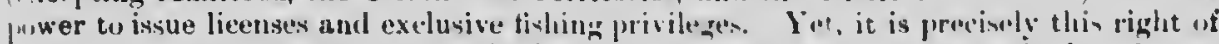

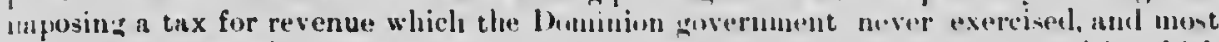

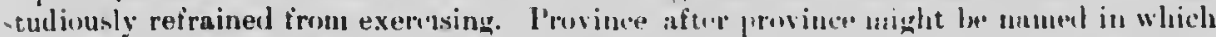

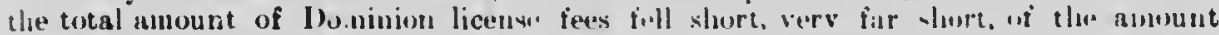

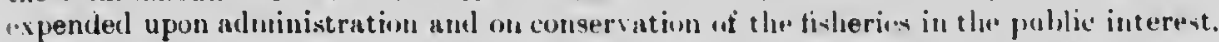

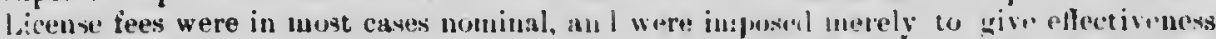
mid force to a system of juclicious control. In aceptional provilicu, lik, that of liritish

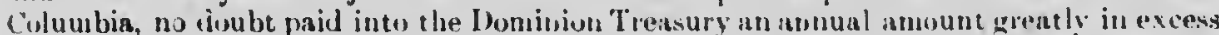

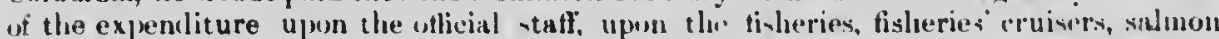
hatcheries, fish-passes an l the like: but -ucli resenue was altogetler unsught anti unforeseen, and was due tu the surprising richnessant rapill devolopuent uf praetioally

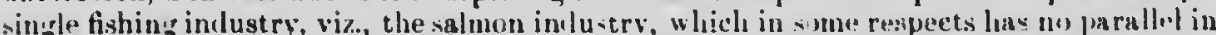
the world. When the Britislı Columbia fishery regulations nero framed the: license teets

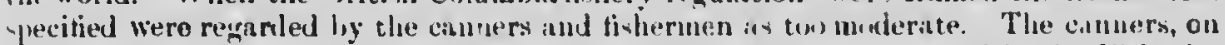

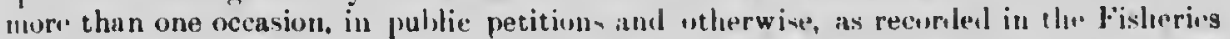
Departunent, Ottawa, filcoured in increase, and volunteretel to livy upun thenselves aditional taxes or feses in order to further artain devirable olycets, $u \cdot h$ as mew tish.

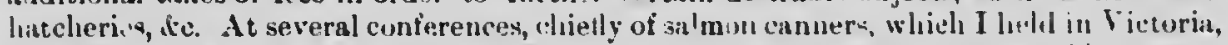
Now Wostminster and nther Britisli Columbia centres, roperentative men lainl itrass on the desirabiity of lerying further assessments upon the canners to prouote the fis aries.

It is real then that, to th principle underlying the policy of the W,umiun government, the 13ritisn Columlia tisheries were no exceptim : and that rogulatims, the enforcement of fees and restrictions, were to be carriel out in the interest only of the tisheries and of the tishing pupulation, in other worls, in the interests of the public. The" system of bunty, paid to Atantic decp-sen finlermen. has lwen by wome parties

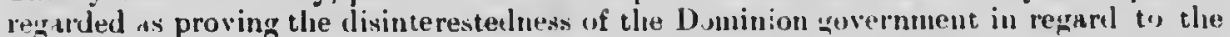
iaposition of fishery license fees; hut it neat hardly In pointerl out that such a sonclusion is inadmissible. The fund which provile, the anmal mount for thepigment of lxunty claims is really a sum paid as compensition hy the l lited siates, totlowing international arbitration, and usually known as the llakitiax Award. The lounty payments are made under nuthority of an Act passed in $1<-2$, intituled 'An Act tu encuurige the

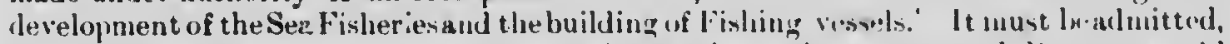
however, that the encouragement of any tishing industry hy a syvem of ifounty would not be inconsistent in principle with the policy uniformly followed in Canalu. ("n the contrary, it would be fully in accordanes with the sirit and pritetice ot that policy. No douto in lividual provinces in the exercise of their rights, defined and teciden wh the Fisheries Judgment, IN9x, lave vigurously followel the reverse plicy and have

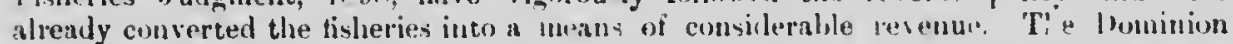

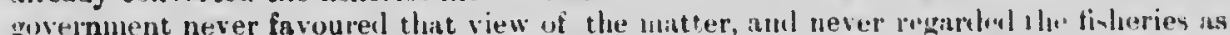

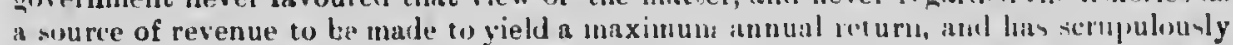
alstainel from impesing "1pun tho provincial iivensess the "tax ly way of licenve tiee"

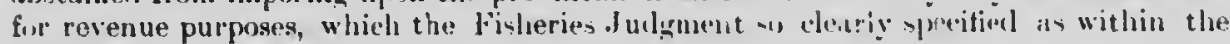
rielst of the Doninion autlorities.

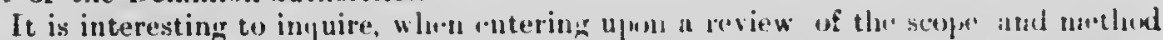

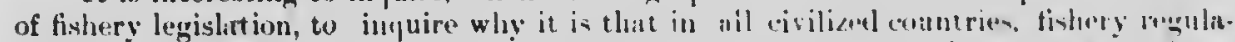

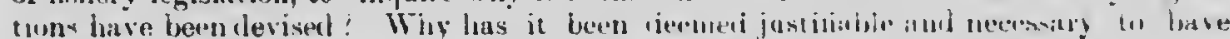

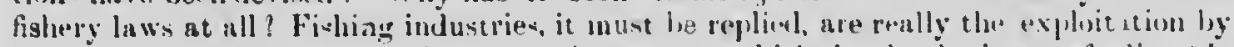

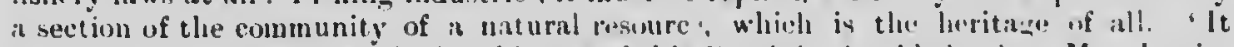

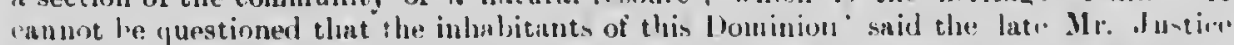
liwvine, "in whatever province they nay losicle, have un interest in the reglation

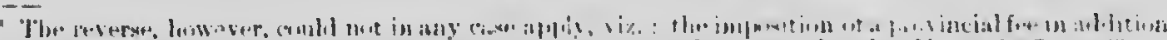

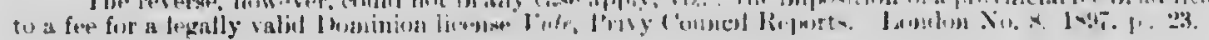




\subsection{EDWARO VII., A. 1902}

and protection of the fisheries, whethor they he sen-const or inland.

and this interest of the public is not the less besiuse in our inlaud waters, consivting of rivers nnl lakres treming witls the tincst fish, private prowons may linve property therein.' * Surll being thr cise, thon whole country, spenking tlirough the legisluture, has the duty and the risht to resulate the fisheries, to prote.t, preserve, and enhance their value anil probluctiveness, as a national resource. The resident on the sen-const has therefore a voice in decidin: whetler or nue inland watres slall he preserved amel rentered more

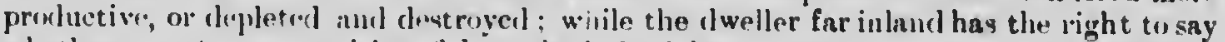
whether or not son" maritime fislipy. Ine it for lobsters, inackerel, seals or whales, shall lie allowel to he deatroyesl or he properly and etfectunlly protected. It is fortunato tliat this is so, for, observat and intelligent as fisheimen arr, their views are often narrow and on "siled, if uot wholly mistakin. They rarels combine to foster the common inte. revty of all of to further the industries upon which they as a class depend. The public have an interest in the ponper carrying on of the fisheries. Is Mr. C. M. Koyes, one of the best known umen connected with the Ohin fisherios, said some years agn "the fixll prorluct of the erriat lakes lias becrime such an importaut article if fond to the vast population tributnry thereto, that laws prohibiting unrensonable waste or destiuction of this valuable conmolit; of cummerce whou'd bis enacted and enforced. The people generally look to commercial tishermen nnly for their supply of fish foorl, and are in a wuy as much interosterl in making commercial tishing a successful industry as are the unen operating the fisheries.'

No doubt the indifference of fishermen generally to the interests of the public, and of their own cliss as a class, is due to thoughtlessness. A Senttish fisherman, in his evidence lexfore the Royal Conmission on Trawling in (ireat Britain (1884), tersely expressed it, 'in the tisheries,' he said, 'it was always a cuse of each haul all, and deuce take the hindmost!'

The Few Fork Fishing filtette, Feloruary 29,1896 , contained a reference to this inportant matter of the attitude of the fishernen towards the interests of the state, and the prition of the fishing industry in relation to state regulation and restriction. and the following extract, it must be granted, suins up the situation most accurately :-

'This industry shoulal not le hampered by laws based on the fanciful theories of th: fish culturist or influcncerl by the argumeuts of the tish vandals who operate on the plan that all are fish that come to their nets, but the best interests of the wholc public should be consilered, and in the end such a system of laws would be to the best interest of the producer and the consumer nilike.'

The position of the fisherman is, of conrse, very unlike tinat of the ordinary labourer or handeraftsman and whol y different from that of the trader or manufacturcr, hence his vicws as to the larger national aspects of liis industry are often peculiar. Like the hun ter's profession, the fisherman's pursuit is full of danger and uncertuinty ; and the humter, as is well known, is too often selfish and limital in his views, and will kill deer or otler gane that should he spired, lest another lunter may secure it. Now, while sea.fisheries may be pursued by any Britislı subject without let or hindrance apnrt from legislation of a limited loenl clinncter, or under conventions with foreign powers applicable only to particular waters, the estuaries and fresh-water fisheries are placed in quite $n$ different category. In the tidal parts of navigable vivers fishing is of common right, unless limitel or superseded by private right - H viry unusual circuinstance; but in non-tidal waters the exclusive right to take fish belongs to the owner of the soil. Unless alienated and slown to have berll trinsfo: red to some grantee, such ownership belongs to the Crown: but in Canada the Crown is represented both by the provinces and the Dominion. As was staterl in the Fisheries. Iudgment, 1898 , waters whether vesterl in the Crown, as represented hy the Dominion or as represented by the province in whicl they are situnted, ąe equally Cruwn propurty and the rights of the public in respect ut of them are precicely the same. For this reason there has arisen sonte confusion and not a little overlapping in the innnagement of the fisheries; but the decision by the highest tribunal in the empire that tlic cnactment of fishery resulations and restrictions is within the exclusive competence of the Dominion legislature and is not within the

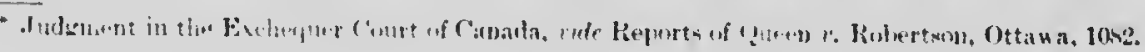




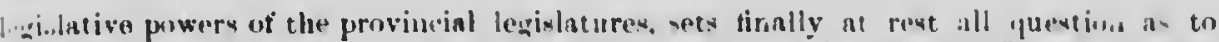

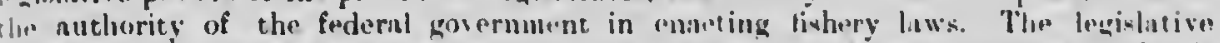

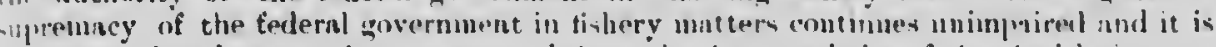

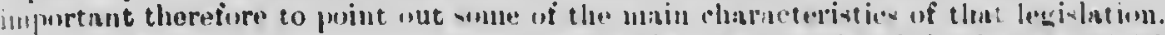

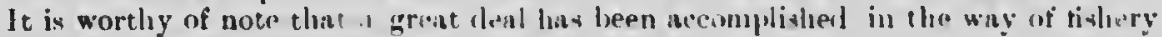

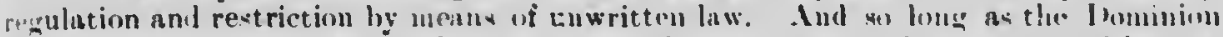

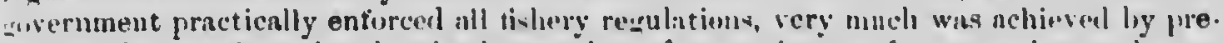
inntion, by moral suasion. by timely wiming of more rigorous future action, and eqpe-

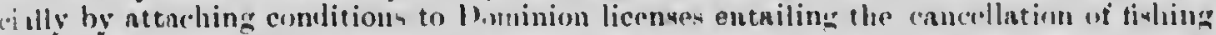
privileges in case of violntion of the resulations. "Flepre was a huclable olesirs, wh the

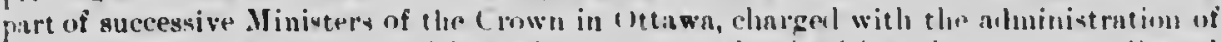
the fisheries, not to unduly multiply uffences ar to make the fishery laws tom complicatud and rexacting. This use of mual leverage, this cxertion of indirect prowume thomgh the license system, worked most succevsfully. and umlue himshnos, tormul legnl pro.

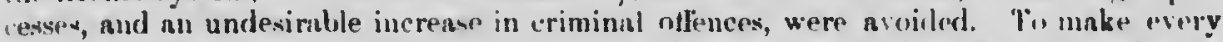
trivial abuse an illogality, an I every olleuling fishorumu deriminal, wns too verious a moasure, and was successfully aboicled by the systein retorrent to.

Of course, all tixhery laws to he effectual and satistactory ought to he busm upou fiscts and upon accurate information. Hore was un initial alstacte. It was diticult t" whtain t:e clesired information irom the tivhing population. while the rival interests of different claves of fichermon, and of the merchants, buyers, packers ir inumers, dic., added to the ditheulty. Fisliery interents hal often to be suborlinitid to cominercial and industrial interests. Ilanufactures wero trefuently given procedrnce. A nohle? river, valumble for ita fisheries, miaht be polluted, blocked by limw and utterly distroyed in the interests of the lumber husiness or of cheminal and entler industries it course, tishery nuthorities have often stated that by exercising $n$ littlo sare and citutinn the tisheries and manufacturing industries coull continue side by side. The utilisation of refuse and wnste products and the exercise of a little consideration on the part of commercial men would have saved trun ruin mang a tine rivel and lakc; lut, in an age of iron, harsh iron methods often prevail.

From : lo outline here attempted of existing fishery rerulations in Camala any historical review or philosophical disenssion of the ultimate uround of fisliery laws nust be omitted. A sketch of the evolution of tishery laws would be supcrtluous. A sir Hanry .laine, in his "Ancient L $2 w$ " showed, $n$ legil enactment in its pre-ent form proves to be, on analysis, not an isolated rule, but the lavt link in nn historical sories, the first liuk in which was probably an arbitrary act of compulsion or an f.r calledru dictuu. 'The series of precedents, which liave yiclded the buly of statutes and regulations now in force started in the assumption, or inther the fact, that tishory rights were vested in the Crown. They night be so vested as matrimonium and copable of alienation, an as hell in trust for the public. Fur was the clam of the Crown limited to rivers and inland watera, or to constal limits. Just as Spain and Portugal divided the Atlantic Gecan between them under authority of a Pupal 13nll 1493, sn Englanl claimed the Sorth Sea or German Oewan, the Hay of Biscay, the Euglish Channel, and the acas noith and west of Irelant, and so late as lint, the Scottish crown claimel the tisheries for a distance of 14 miles from low-water mark, as is specitied in the draft Treaty of Union with England. When private parties or public luxlies aequired tisliery righty as grantees of the Crown, such rights w.re exercised nnler regulations. Thus in sicotinnul all salmon fixhings are enjoyel by Koyal yrant : hut from the earlieat times the holclers were required to observe strict conditions imposed in the public interest. Av early as 1175 , a Statute of William the Iinu repuired cngines and traps to be so sct as to leave i pisaage clear in mid.strenm for the ascent of the inigrnting tish to theil spawning

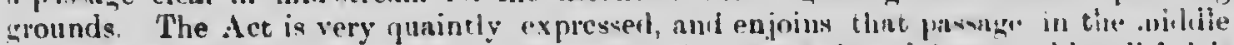
it the stream or river is 'nye to be free sie muckle as a swine ot :? years old well.fol is of length soe that neither the smonic (smout) nor th. tail may win toe ony :icle.' The tatute also shows the antiquity of the obvervance of sinblistl rest even for salınon in ic)tland, for it provides thit wo fiah shall be taken from saturdy evening until sunrise on Ifonday. Inny statutes of a similar uature all directerl to reatrain ccrtain modes of fishing continued to be passed by Senttish Parlinments down to th" (ante of the Union. The objects of tlese stintutes, according to Lorl Westbury, were three in 
nuwber-." "ne to insure to the salunon a free aul unimpeded nccess to the upjer fresl whters which ar. tha nitural spowning grounds of the tisll. The secunt to secure the unimperled roturn to tle sen of the smolt or young fry of the salmon. The third to prolhitsit the killing of melean tislı.'

In Cunata the C'rown is represented by both the Jominion and by the Provincrs, and unucl complication lus resulted, in conseruence, in the interpretation and adminis. tration of fishery laws. French seignorial rights, too, enter into the matter in the Province of Queluec, and in New IBrunswick. But apart from these ligher and nor" dificult aspects of fishery law and tishery prerogative, there remains that pructical sile of tislery legislation, which las directly for its object the protection and preservation of the fisheries un a untional resource.

The basis and ain of fivlery legivlation nay be said to be fourfold; or rather four main interests lase lecn proninent in the framing of tishery regulations generally. These are: First, - the interests of the fish. If there were no fisl there would le no fislicrmen and no tisliug industries. Hence tlie preservation und fostering of the fisll. qupply in their native waters is inperative. Second, - the interests of the tisnerul" 1 as an industrial community. The body of fishermen have legitimate rights, which must les recognized by the state. The rights of lalour cannot and ought not to be ignored, and the fisheruen form an impurtant part of the population in most countries. Both on nezount of their numbers, of the householils dependent upon them and on account of otler iulustries involved in and bound up with the fislieries, the fishermen have is recognized clim to consideration. It is hardly necessary to point out tliat net and twine niaking, boat-building, barrel and box-making, tin and can factories, ico and salt industries, and the like, depend very largely on the tisheries. Their impoitance is vast and far-reaching. Third, - the interest of the state as a whole. The interests of the state, or 14 it is commonly expressed, the public interest, may not always coincide with the first or second interest lescrilsed above, indeed thcy may come into serious collision, and many authorities might lwe quoted to show that the public interest shouli be par. amount and that all the interests enould be regarded as of secondary impurtance. The most patent case to the ordinary crizen is that of mill-owners blocking by dams, or diverting the channels of important rivers for their own private business purposes. The Suprene Court of lowa, in a case be..- them two years ajo, publicly expressed it. view as follows:- The strenms and lakes are the nutural aliding places for the tisl. In them they cast their spawn and multiply their species. They constitute an inpor. tant and valuable article of diet for the rich and the poor, anl, with the ways open that bature has provided, they are accessibly to both. If the lowest riparian owner of a stremu may legally block the way of thoir nigration, the consequences to result to the thousands are rendily inaginable. The law that would permit it would le: the entering wedge by which tle few would profit at the expense of the many.' Fourth,-International interests, which may affect the conity of nations and which have often reached a stage so crucial and perilous as to overricle the interests of tlee fisl, the fishermel and the nation, requiring these interests, indeed, to a large extent, to be sncriticed to avoid momentous and lasting evils, such as foreign unfriendliness or even wal. The imminent danger of armed conflict has more than once shown that interuational interests are of suprene signiticance; but, at the same time, the lesser. interests have been frequently insisted on, and opposing international claims and pre. tensions lave been set uside or compromised. The history of international tishery legislation is, indeed, a listory of compromises.

In the foresoing summaiy the interests of the fishermen, or rather of the fishing imlustries, liave been referred to as one, as though it were possible to reduce then to a simple type easily understood, and succinctly stated. But such is not the case. The rin! interests of differeut chasses of fishcrmen furuish those officers, eharged with the administration of fisliery regulations, with some of their most difticult problems. Fishermen often tall into oplosing classes on account of their different inethods of tishing. The stenm.trawl fishermen on the eist const of liritin and the long lin. fisheruten were long at war witl each otber: the lolster fishermen of New Brunswick wrie legardel by the salmon tivhermen as a most injurious class, just as the suggested use of sahmon traps in British Columbia has been most bitterly opposed by the drift- 
1:0t tishermen of the Straits of tieorgin and the liraser IRiver. It is unater of emumon

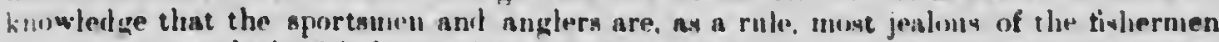
wh use nets ani who fish for market : while even such slosely mated vixations as ovster

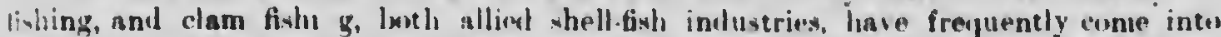
notlict. It is less surprising, lwwever, that fish canning and packing industries should be wten opposed to the actual fishing inlurtry, wa the interests ot those who merely hancle and put up the products may freigantly differ from thowe who secure tho raw jroluct, viz.: the fishermen. Packers amb comnarcial nuentw mny wish to linit the supply owing to the state of diutant unrkets, when the fisheruneil wish te lisjome of

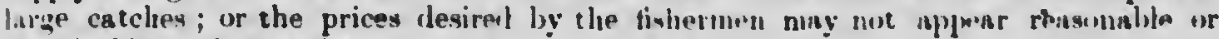
particable to the merchants.

In the whole, however, these various infereste converge, and nu the tislinerne'll and

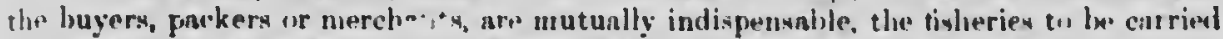
wis successfully, reyuire the unteal efforts of all concerned.

I huve stated that tishery law* may les grouped in four categuries, currodpunding

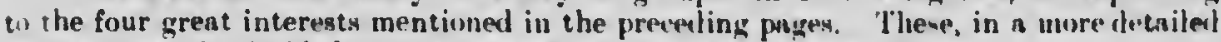
manuer, may be thivided into ten separato divisions as sel forth lwow.

(1.) Laws designed directly to preserve and pr it ct tish. They may be sulxlivited a. follows :-

(a.) Close times enforced for a few hours only daily, or on a certain weries of days, like the regulation regarding dipping for guspereaux or alewives in Nova veotiastreams.

(h.) Weekly cluse times of "24, 36 or ino a huurs weokly and known at sunday close times devisent to secure the safe passage up.strean of part of each ascending schoul of tish, especially salmon, to the spawning gruunds. Most walnon authorities liold that if a tew breeding fish of each snlumon schwol be allowed to pass up, including tho anlier and later schools, a river may be kept in gond productive condition. The Twemd rialmon Comnission, Scotland (1896) laid stress (in that fact. Such a weekly elose timecovering 4.2 hours in the sulmon riverw of British C'olum.lin is frejueutly remered inetfective by th" netters, who on Monday morning go as far up the river as the law allows and orertake the fish which passed up during the prohibited hours of the alay lefore (Sundiny).

(c.) A short clost weason such as was tried for some years il British Columbia covering three or four weoks during the later run of salmon, with the object of ensuring the safi" wicent of a sutficient numier of fish. These fish lyelongerl to the early scluols of coluse o silver salmon (until recently of no great ecouounic imprtaucis anil the late ruu of sockeye or blue-luack salmon, which in nany cases are nut suitul) for cannind leing soft, ripe for spawning, and in pour condition for market purposes.

(1.) The detinition of a minimun size limit, lelow which none of the kinl, of tish named can le taken, is another effective protective devicr. It nius to protret im:mature and undersized tish until they breed. Thu, hosters are stateil not to breml until 9. wa bong-lience n ! inch size limit has Inen enforced

(e.. A size limit may be pnforeed on other ymunds, as fur instunce the 10 inch lobster linit in a portion of the Bay of Fundy. The remuner.ıtive markets of Buston. I. S., would not accejt bolsters under 10 inches in lenutl. hende certuin Cisnadian tivhermen urget that this limit be specificl in our laws and such a law was in certain witer carried out. The size limits for trout, black bass, aul many other fish hive heen spocified in the general interests of the fishery or in annf t'ases, of sjwrt.

(t.) Mesh of net regulations aining the same oi,ject, viz. : the lilu'intion uf small useless inmature tish.

(y.) A sperified distance between the shats in lolster traps or a specinl mosh iu leaders of trap-pound, to tiswu he capture, only wi sisenhle fish : or the nuning of a minimum diameter and length as in the case of aysters un order to recure that those unclersiced shall not be taken.

(h.) Prohibitions en'oreed which forbid the taking of tish spawn. the catehing, killing, or even possession, of try and sumall sizerl tish, the young of any of the tiah mentioned in thiv Aet' as it is expressel in the Canndian Fisheries Act, chap !i:, 1. 1). 18s6. While aiming to prevent the destruction of ureters snall tish, it also forbids practically the stocking of new waters with small fry, which might, ind oud, loe 
a serious inj.." to such waters unless sunctioned by qualified exports. Fish nnd tish

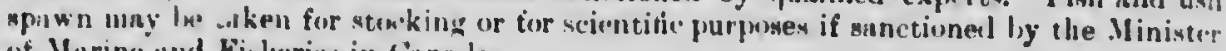
of Marino and Fiolowios in Canmla.

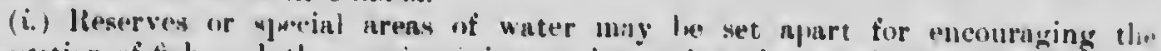

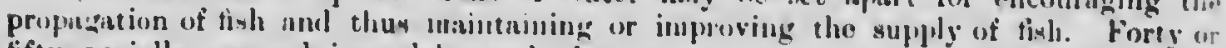

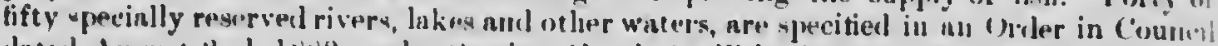

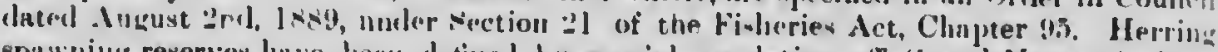
spuwiug reserves have leesl defined by special regulntion off Grand Manau, in New

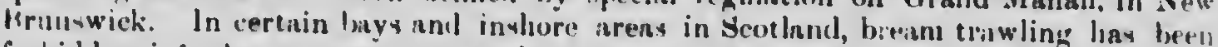

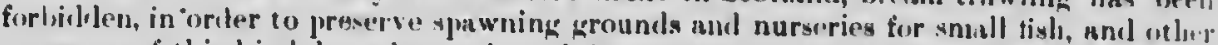

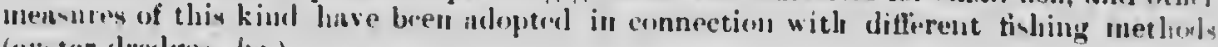

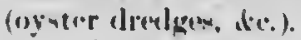

(j.) Improwement of fisluerimand the incrrase of desiruble tiall is often souglit by tle. withlrawal of protection of vorneious species riuring the spawning tiole or the curtailinent of their close senson. Sulıun.trout or lake-trout are thus kept in clıeck by

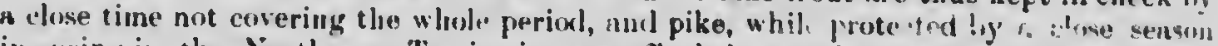
in -pring in tlos Sortl-west Territories, are aftorded no sucl protection in Ontnrio sul the rastern provinces of Cnumln, where they nre of inferior quality and value.

(2.) Control of tho fivleries, which is nduittedly wive and in the public intere.t, is nelieved in various way's such an,-

(a.) Idicenser, lenses nnd permits involving more or less pxacting conditions in the exercise of the privileges convoyed.

(b.) Licenses or other permits ginutul with limitations so as woxclude foreigners, or prevent overcrowding or use for speculntive and similar purposes. Sites or fishing locntions which nre cindevirable and useless may be applicd for to give the holder a claiu niter a while to so.: otlier betur location which would not nt tirst have been granted. The limitation nay involve refusal to allow uets or tishing genr at particulnrly favousable and destructive spoty, sucl as a projectur point "t the mouth of a salmon river.

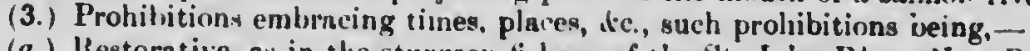

(a.) Kestorntive, as in the sturgeon tishery of the St. John River, New Brunswich. and extending over $n$ number of years, deened sutticient by the authorities to restore the depleted sturgeon nupply. Striperl bass in the Jiramichi River were simility protected, and witli complete success, as was proved at the end of the third year.

(1.) Preventitive, as in the forbildling of non-tidal saluon nets in rivers; cod-trawls or luultows, which nre loug lines of haited lwoks on snoods, and laid aloug tho bottou, and objectionable because of their alleged destructive effects upon breeding fish, and similar prohiloitions of genernl npplication.

(c.) Local prohihitious specially applicable to particular localities nnd districts e.y. pound aud trap prohilitione in Manitobn and in Georgian Bay, Ontario, or the prohitition, for mnny seasons, of seines in Ontario, or of oyster dredges in Richmond Bay, Prince Elwall Island Sialinon nre not to be taken ascending " pass, a leap or iı a loreeding pool.

(d.) Universul prohibitions of nefnrious and injurious methods, fe., which covers the use of dynnmite and explosives gunerally, also submerged trap-ne:s, fish spears, and purse spines; nll of which methols while effective, are too destructive to be regaidel is tair and legitimate means of capture.

(e.) Aipecial prohibitions sucl ns that prohibiting the taking and handling of snlmon spawn : but not tint of trout or any other fish : a prohibition basal no doubt upon the seutiument prevuiling in old comntries that sahuon are entitled to more protection than utlır fisl. A peculiar regulation-special even nmong 'S Special" regulations, is that ocintring in tlw. Canadian Lobster liegulations passed in $1 \times 99$, which enjoins that 110 "rst slatl buy or sell mutialed lobstrs ur broken lobster meat. The object is to prevent evaion of tho lotwity size linit regulations, it heing impossible for tishery officers to detect vinlations if tishermen could landle wilfully broken or mutilated lobsters.

The serious mature of this nefarious procedure is being felt in the kistern States. aml the fullowing, taken trun the N.Y., Fishing fiazclle:--

A lobster pirnte is inakio a gool revenue in the waters of the Maine $y$ buying short libsters at 2 c:nts each from the fishermen and hoiling thetir on a stenin launcls 
nol tish linistı'r

is w ich. restore uilarly

trawls otteni, h, and

cts e.y. rohiliid Bay, $r$ iII a

covers $r s$, and del :

almon on the thinn is that hat III resent ers to Sintes.

"lich he has fiteal up with a loviler. Ho hrouks tho mils and relaw frome the lobsters

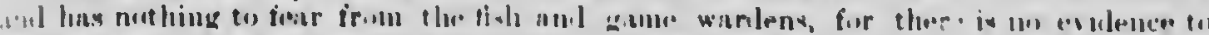

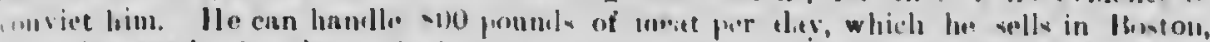

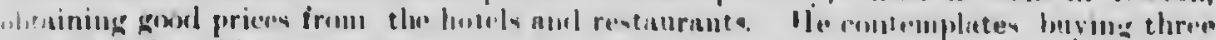
purero launcloes this sumumer.

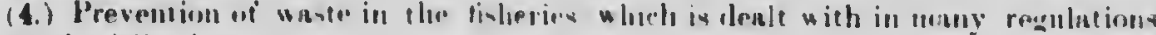
-181, as the tollowiug :-

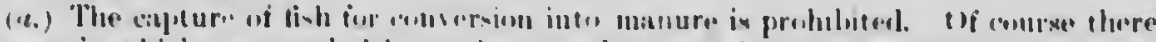

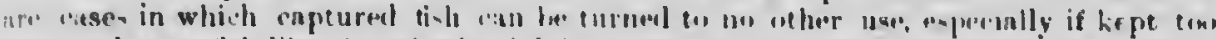

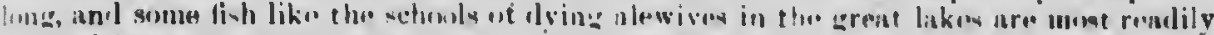

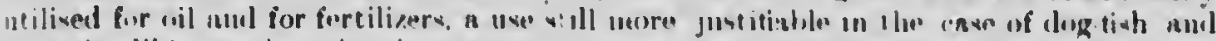

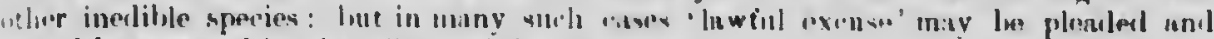

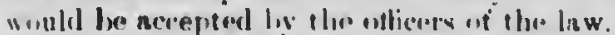

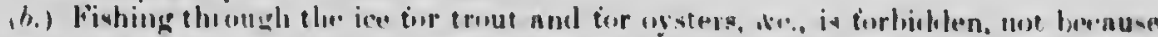

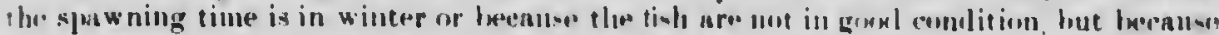

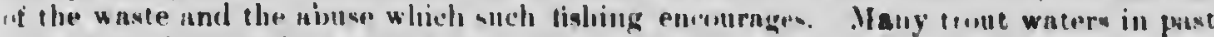

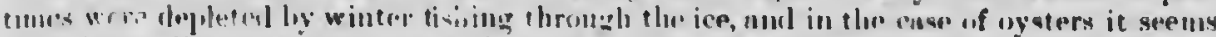

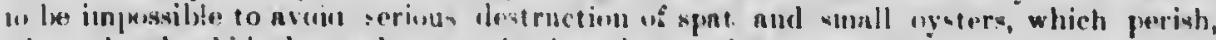

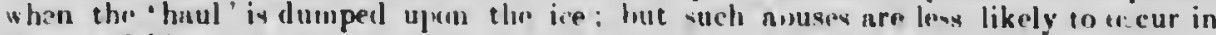
stmmer tishing.

(c.) Pirntes nrt: reyuired in solu provinces ut tho intuke of irrigntion ditches tu pre. selt tho ascent of simall tish from rivers nnll lakes.

(d.) It tre unbaite: heviks or trawls fur sturgeun are prohiliteml in urder to present

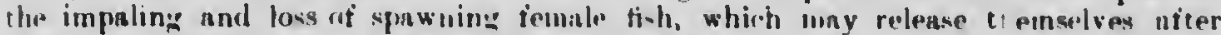
lwing severely injured and as a rula dic nut nre wusted.

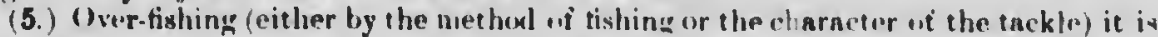
sought to prevent in various wnys: (u.) I duitution of lengtl of net and numlier, or by specifying the numle.r of lomks allowerl out a long line, ife.

(b.) Vroviding for an alepunto distance Ixetwien neta, traps, weirs, mul tixpd, ur moving, nets gentrally.

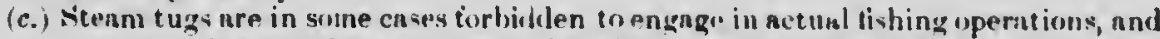
may consey crews, boats aud genr, ol anry tlep tukes: but not actually ti-h in such ca es,

(d.) Jimitation of the nomount of catch ur quantity to he legully shipperl. This spacially applies to game fish ond like the laws aguinst jut-lunutinn fur game, has foren chiefly ngminst undesirable intruders from th" Uniterl Sitates, nut true nnal legitimnte spontsmen.

(6.) Laws to incilitnte the migrntions of tish w und from their feediun und breed. ing grounds have been ennctod on the tollowing lines:--

(a.) Obstruction to the nscent of tish tro spuwning resorts are forlidelen.

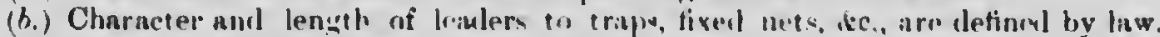
s.nelt hag-nets for fxumple have bren fouml to have very long loalers of brush or wickerwork which renuler these nets tur dentructive.

(c.) The main channels of rivers way mol bo obstructel nud mo net shall extend mole than one third of the brealth of such river $1011 \mathrm{~s}$.

(d.) Fishways must he proviled at danı, do., if judgerl to bo necessury by the

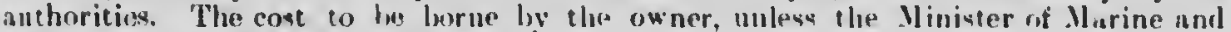
Fisteries consents that half lo paid.

(7.) Protection of interests of tishermen and partios enneurned in the fishermes is sumght hy special regulations.

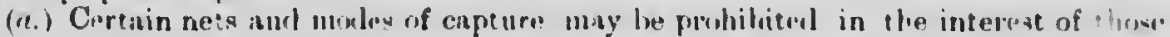
estab!isher in the industry. Thus in the Bay of Quinte, seill-nets in summer :.1.. nut allowed hecause the uets eisily rot whell ural thore, and whilo a fow mon wr. d us:

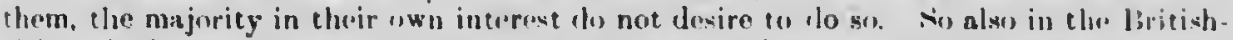

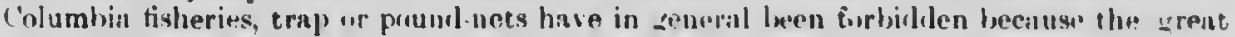

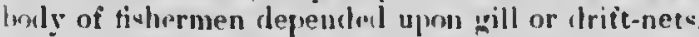

(b.) Salmon canners in Butivh Columbia though not atetully tishermen wer"grantert

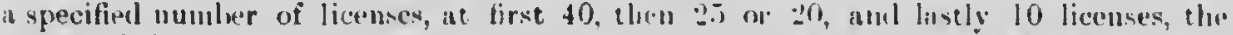
purpose being to secure the anmer from h.sty or injursus action by the fishermon, who 
might refuse to fish, and put the canner in serious difticulty at the height of the season. There is of course no liecessary connection between the canning of a product such as salinın, and the capture of the fish by fishing. In some remote districts, where reliance must be placed upon Indians, unless the canner had licenses granted to him, he might not be able to operate at all. Yet a canner is not is tisherman any more than a tailor is a farmer, although woollen cloth necessitates the prorluction of wool on the farm. In view: of the canner's vested interest (his capital and outfit) he has by law been considered as entitled to fisling privileges.

(a) In order to meet fislı-buyers needs and trade requirements, regulations have been moditied ns in the case of the Sunday close tine which is really a Saturlay close time on Lake Winnipeg for special tride reasons, ancl in British.Columbia the Sunday clase time cnds at 6 p.m., not midnight, for the benetit of the cannerirs.**

(d.) Similarly, regulations exist compelling one class of fishermen to desist from fishing at a specified tim $e$ in order to meet the desires of another class. In southern New Brunswick certain nets in the sen, it las been urged, should by law be required to bis taken up at diaylight to meet the wishes of other men in the locality.

(8.) Regulations of the nature of precautions form a distinct group by themselves. The pussession of illegul nets and apparatus would he a most effective measure in this direcion : but being difficult to justify, is still in fuluro: but the following are noted :-

(a.) Fisling in the mouths of rivers with seines is forbidien, ant a specitied distance is named in the regulatious with reference to that.

(b.) Fear salinon nets other apparatus, such :1s lobster traps, must not be set, on the ground that the tish would he deterred from entering the nets, and the hauling of the lobster traps would drive the salmon away.

(c.) Preparing to fish, like loitering or suspicious cond uct under the Criminal Ciale, may he criminal under the fishery liws. Such precuutionary ineasures prevents fishing operations before the opening of the legal time, or renders it impossible for one party to monopolive anothers ground by taking possession preunaturely und preparing to set tishing apparatus.

(d.) The presence of dynamite or exploxives on board tisling vessels for the purpose of killing fish is unlawiul in aceordance with a recent regulation (April 12 th, 1902)
of a rather exceptional character.

(9.) Injurious influences affecting fish-life and closely bound up with sanitary questions, have formed the subject of much fishery legislation. Existing regulations have been framed on two lines:-

(a.) As pollutions injuriously affect fish, tish-life nnd eggs upon spawning grounds.

(b.) As pollutions annoy and leter nigrating fish, especially when entering or pas. sing up rivers. An offal prohilition in the Gulf of St. Lawrence was lased on the allegerl disapparance of the schools of cod from certain lucalities in Lalsrarlor on account of the offensivi tloating gurry or putrefying tish-waste in the water. In the Fraser Kiver the offal from the canneries has also been regarded as harmful and therefore forbidal en by lnw.

(10.) Reruhtions aiminer to secure quality and purity in manufactured or prepared fivh-products are included under fishery laws, though strictly speaking they belong to
tracle and commercial legislation.

(a.) lim uling of packages and barrels witlı an ofticial stamp, after strict examination and approval, las proved most effective in Scottish cured herring. The brand has given then the status they hol, is perhips the finest quality in the narkets and for tracle purposes divided into several recognized grades.

(b.) Stamps on cases or cans specifying the legality of the time and senson when lackerl. Thus Canalian lobsters, if not bearing, outside the woolen case, a tinted -tamp, are thereby recugnized as unceisonable and in most caves as illegal goods.

(c) Certin custons regulations proctically coincide with the objects of some fishery law, as in the case of 'nited Stutes, States' saluon imported free of duty by a special concession, into british Columbia, the main consideration against sucl concession being that the tisll, as a rule, were in lad condition, often wholly untit to can, on account of the circuis.

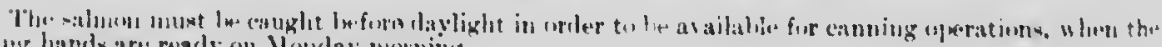

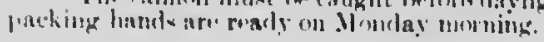



equired

aselves. in this ted :ied dis-

set, on

ling of

I Cixle fishing e party to set he pur, 1902)

rounils. or pas. on the uccount Fraser erefore

ejared long to

anina. nd hits und for when tinted

fishery ial colloy that ircuin

\section{SESSIONAL PAPER NO. 226}

- tances of capture and transit. In the crouded [nited States trap-nel- the fisls ale ofien torribly crushed and mutilated. aml atter being dumped into a huge seow may lie ex proml for lours to the hent of the sun in .July or Iugust. and the clowe of the more or lose longthy trip. from the net to the cannery, they luve wholly detcriomtinl, mul. it is alieged, may be in a state of semi-putrefiction. No eloubt eanners of tish are treejuently

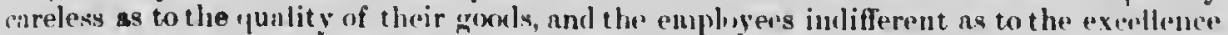
aml appearance of the commudities they pack; lut this is not always so. .lany firus litve a constant and strong desibe tw establish and to ke'p up a gomd roputation, and onme go so tal as to insizt that the gusernment shall step in nud insist on a certain stumlard of yuality in the fish prodncts marketed. Five or six venrs neo a prominent man in tha"

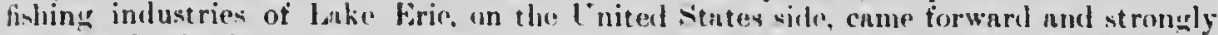

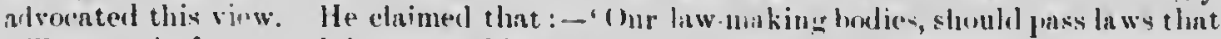
will mit only foster and inclease this great industry. lut will also compol glealere mml shippers to prorluce and senil to the consuner, wherever lie may lo located, this valualile fort promluet in the most perfect and wholesome comblition posible. The puple have a bight to this protection and should entiure their just demands throush the medium of thirir respective legislators.

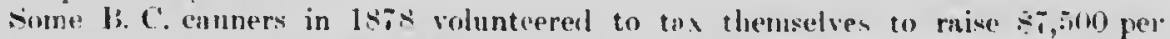
annum to promote the tisheries in aldition to the usual license fores, and, later favoreal a Government Brand or Stamp ou packiga of Fiaser Riser tish.

The sardine inclustry of $\lambda$ aine, the lobser canning industry in certain Canmlian lrovinces, thr herring trale of the bominion, as a whole, has sufferol frum the indiflin. rence of fi-lierinen and packers respecting the quality af the prodnets sent intu the mathet.

Ten years ago I reported on thr quality of the dricd col shijperl by certain Sova Sotia forms to the $i$ nited States, and l pointed out that whereas aur col renlised only pert quintal. the Norwerian drieal col prepared more carefully aul intelligently brought as nuch us * prepared by the Lnited states curers generally, the provlucts of the latter rarely lealising wore than 84.50 par quintal. The less finery regulations lowever trinch upon mattiers puralyof trade and comberce the mure they fulfil there origrinal purpose, the protect on of tinh ns a great natural resoure. of the country. Regulatiuns such as the provin "ial prohibition, forbielding trespass upm premisen and waters leased for purposes rit fivle ry*.

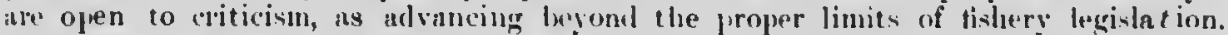
liven affences against the fi-liery icgulitions torbidifing the pollution of rivers ind lakes may often be more effectively and npjropurintely dealt with by lucal henlth autlorities under the Puhlic Health and Sanitary laws.

It is not the purpose of this skefth to invado the sonewhat controversial and perilous field of intermational law as alferting finlories. The above summary aims, rather, to outline the main types of fishery roulations as illustrated in our Cantdian laws, accompanied by a lorief snegestion as to their rational and hatsis: lut it does not in any way profess to he exhinstive.

It such an outline lorings out the main foutures of existing legislation, and it it removes a uy misconceptions regarding its ain and purpuse rather than its forn or literal expression, th' olject in view has lwen fully iccomplished. It will le: "pparent that the" ten main grolips of regulations roughly taluslated, and the forty-two sululivisions into which they fall, cover the four main oljects of all tishery laws:-the interents of tho tish. the fishernen, the state, and of foreigners with which wo have relations on tishery matters. These tour whjects embrace the asontial aim if all li-hery legislation ; hut its method is very diversitorm, as has been indivaterl. The tondenty hax been to inultiply the detailed forms of fishery rigulation chiefly in respons. to supposel tocal peculiaritio.s and special eonditions of the fisherum or the tinh. The bane of fishery renglation is complieation and diversity in local detilil.

There is no cours, in the long run, mor" wise and wote beneficial than a resolu!e "lpposition to lasty, ill considered and facile multiplication of detuiled fisliery refula tions. If carried to excess it nullities regulation alogrether, for un inws can he wuforini, which apply only in restrieted areas, or for petty reasons. If a fish fol eximple cull we

" R+v. Natutew uf (Inlariuc. 32., 4. :G. 
legally caught in one urea at the sine time that it is prohibited in the next area, puaching will go on all the time, and any illegal tish detected in one district will lee declared to have been taken in the wher district. Fishery laws, the fewer and simpler they are, will lee all the inore effective and beneficial for the reason that they are more essily unilerstiod, and that there is less excuse for wilful violation. Canndian fislery legislation is all based on the Fisheries Act, Cinapter $95(1886)$ which consists of sections and 68 subzections. Under the Britisli Nurth Ametica Act it was held that the Canadian Parlinment laad power to enact these Statutory lRegulations, though, as already pointel out, certain of the clauses are now declared to be invalid and ultra rives. Since the date of the statute, $18 \times 6$, nuinerous amendments and additions liave leen inade, at least four new sections (consisting of 22 subsections) have bcen added, and 5 other subsections appenderl, while : new sectious (one embracing 9 sulsections) ha we been substituted for old ones, and 8 old subsections in addition. repluced by now one. Ono section of the Act has becn repealed totally. Few fishery " lations enacted in recent years are statutory, no less than 309 Orders in Cuuncil . bodying new fishery regulations have been passed since 1890 , sucl Urders in Council having under section 16 of the Act (1886) the force of the Act itself. The reluction in number and simpli. tications of this furmidable series of legislative enactments is most desirable, but a useful and inclusive body of regulations cul unly be framed, after deliberate and exhaustive consideration of the fisheries as a whole. Hasty and ill.considered legislation is at once a danger and an injury, as Mr. C. E. Fryer, one of His Majesty's Iuspectors of Fisheries, said at the Great Fisheries Conference in Iondon, July 27 th, 1883 :- ' One of the greatest evils to which any industry can he subject is that of spasinorlic legislationlegislation framed to meet a popular cry of the moment. Among a certain class of people whose view is bounded by the horizon of their own particular standpint, a demand for legislution is heard on every imaginable pretext.'

Jishing laws are too serious in their effects, direct and indisect, upon the fishery resources of the country, the welfare of the fishing population. and the interests of the state to allow of ill-informed, one sided or hasty formulation of regulations aud injudicious or hlindly rigourous enforcement. 


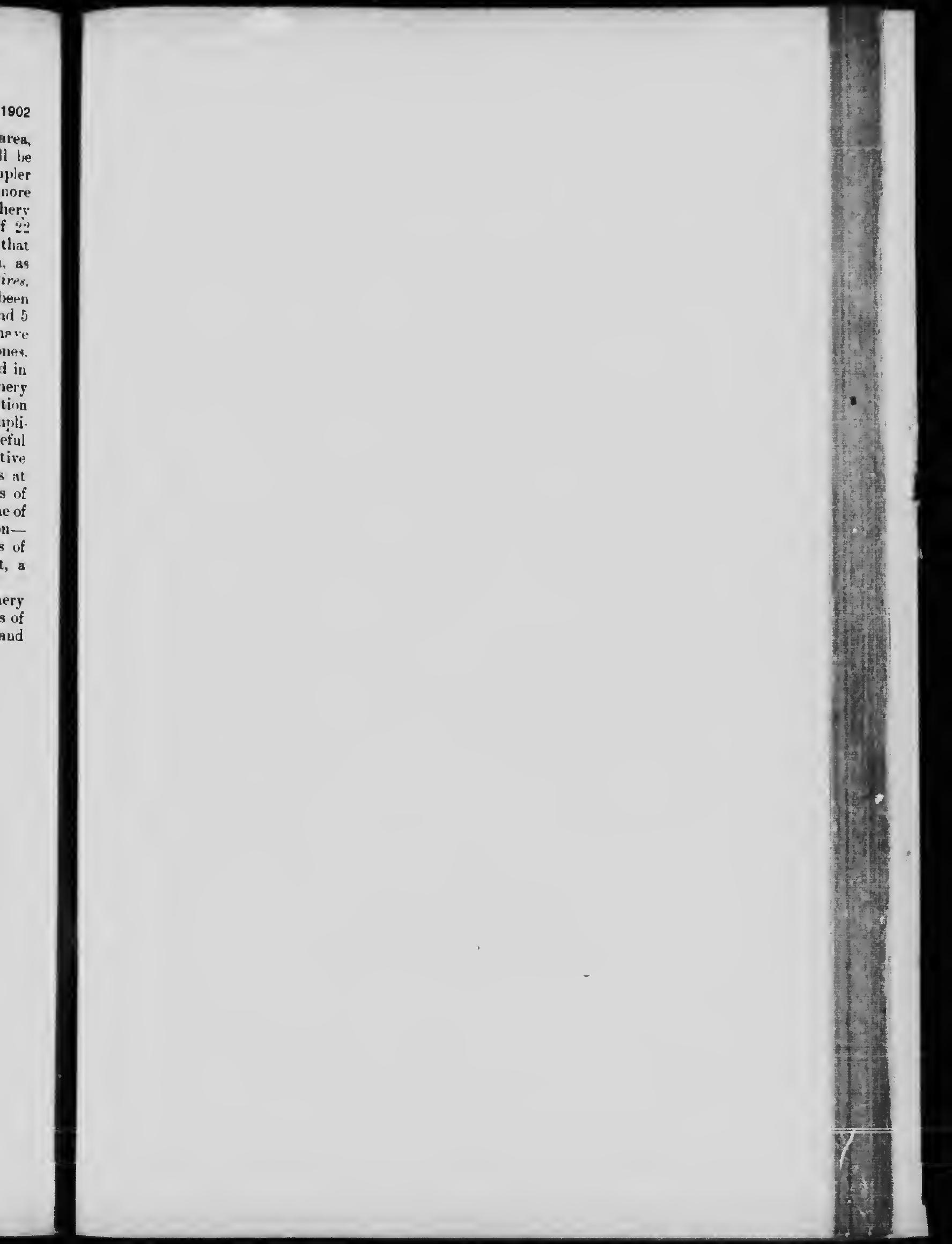




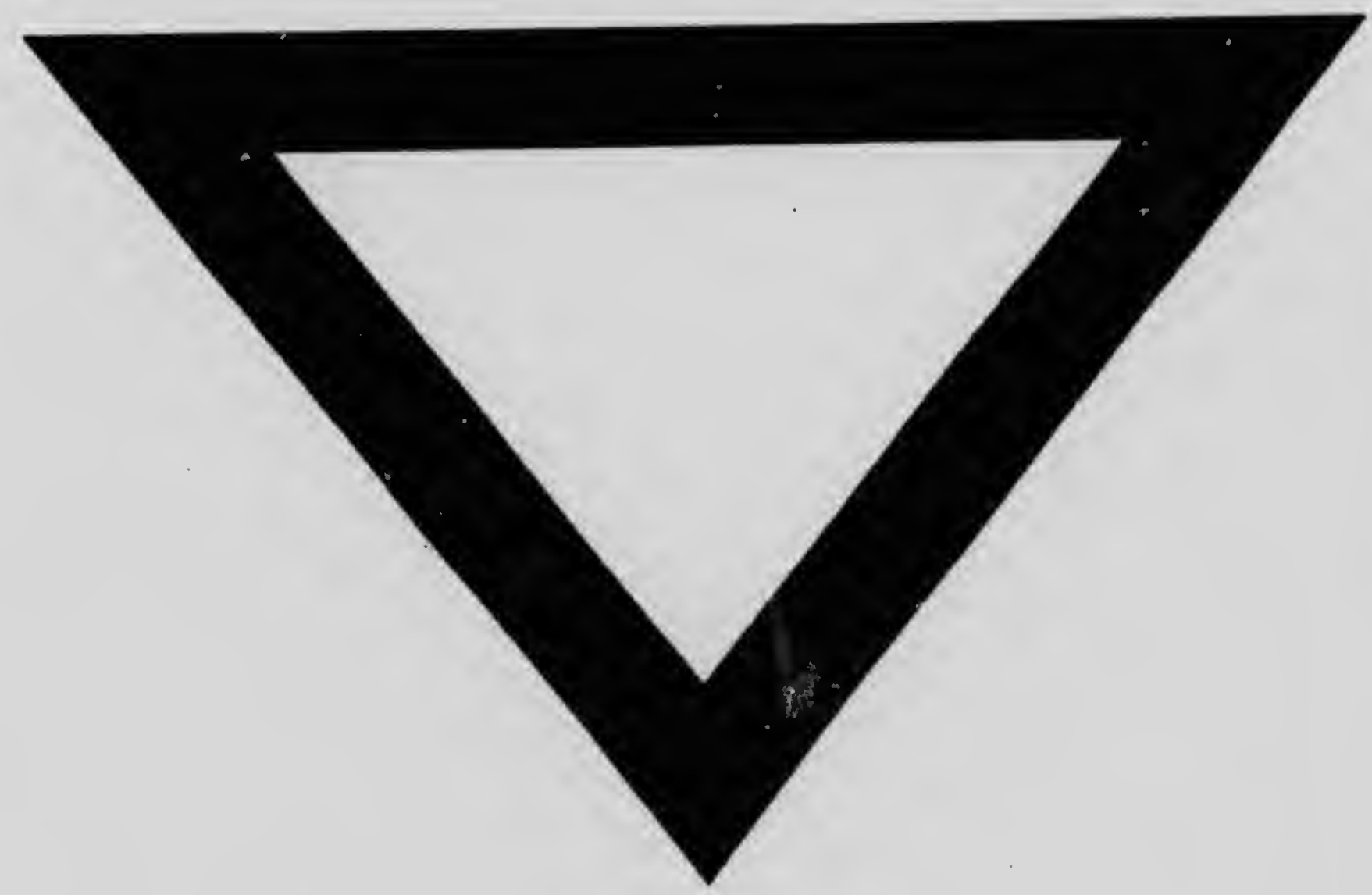

